\title{
Growth of Yersinia pseudotuberculosis in human plasma: impacts on virulence and metabolic gene expression
}

Marie-Laure Rosso ${ }^{1,6}$, Sylvie Chauvaux ${ }^{2}$, Rodrigue Dessein ${ }^{1}$, Caroline Laurans ${ }^{1,7}$, Lionel Frangeul ${ }^{3}$, Céline Lacroix ${ }^{4}$, Angèle Schiavo ${ }^{4}$, Marie-Agnès Dillies ${ }^{4}$, Jeannine Foulon ${ }^{2}$, Jean-Yves Coppée ${ }^{4}$, Claudine Médigue ${ }^{5}$, Elisabeth Carniel ${ }^{2}$, Michel Simonet ${ }^{1}$ and Michaël Marceau*1

Address: ${ }^{1}$ Inserm U801, Lille, F-59019, France; Université Lille II (Faculté de Médecine Henri Warembourg), F-59045 Lille, France; Institut Pasteur de Lille, F-59019 Lille, France, ${ }^{2}$ Yersinia research Unit, Institut Pasteur, 28 rue du Dr. Roux, F-75724 Paris cedex 15, France, ${ }^{3}$ Plate-Forme 4 , Institut Pasteur, 28 rue du Dr. Roux, F-75724 Paris cedex 15, France, ${ }^{4}$ Plate-Forme 2, Institut Pasteur, 28 rue du Dr. Roux, F-75724 Paris cedex 15, France, ${ }^{5}$ Génoscope, 2 rue Gaston Crémieux, CP5706, F-91057 Evry, France, ${ }^{6}$ Unité de Prévention et Thérapies Moléculaires des Maladies Humaines, Centre National de Référence de la coqueluche et autres bordetelloses, 28 rue du Dr. Roux, F-75724 Paris cedex 15, France and 7Fédération de Biologie, Centre Hospitalier de Roubaix, 11-17 Bd Lacordaire, F-59056 Roubaix, France

Email: Marie-Laure Rosso - mlrosso@pasteur.fr; Sylvie Chauvaux - chauvaux@pasteur.fr; Rodrigue Dessein - r-dessein@chru-lille.fr; Caroline Laurans - caroline.laurans@ch-roubaix.fr; Lionel Frangeul - lfrangeu@pasteur.fr; Céline Lacroix - clacroix@pasteur.fr; Angèle Schiavo - angsch@pasteur.fr; Marie-Agnès Dillies - mdillies@pasteur.fr; Jeannine Foulon - chauvaux@pasteur.fr; JeanYves Coppée - jycoppee@pasteur.fr; Claudine Médigue - cmedigue@genoscope.cns.fr; Elisabeth Carniel - carniel2@pasteur.fr; Michel Simonet - michel.simonet@ibl.fr; Michaël Marceau* - michael.marceau@ibl.fr

* Corresponding author

Published: 3 December 2008

BMC Microbiology 2008, 8:2II doi:I0.|I86/|47|-2180-8-2II
Received: 2 July 2008

Accepted: 3 December 2008

This article is available from: http://www.biomedcentral.com/I47I-2I80/8/2II

(C) 2008 Rosso et al; licensee BioMed Central Ltd.

This is an Open Access article distributed under the terms of the Creative Commons Attribution License (http://creativecommons.org/licenses/by/2.0), which permits unrestricted use, distribution, and reproduction in any medium, provided the original work is properly cited.

\begin{abstract}
Background: In man, infection by the Gram-negative enteropathogen Yersinia pseudotuberculosis is usually limited to the terminal ileum. However, in immunocompromised patients, the microorganism may disseminate from the digestive tract and thus cause a systemic infection with septicemia.

Results: To gain insight into the metabolic pathways and virulence factors expressed by the bacterium at the blood stage of pseudotuberculosis, we compared the overall gene transcription patterns (the transcriptome) of bacterial cells cultured in either human plasma or Luria-Bertani medium. The most marked plasma-triggered metabolic consequence in Y. pseudotuberculosis was the switch to high glucose consumption, which is reminiscent of the acetogenic pathway (known as "glucose overflow") in Escherichia coli. However, upregulation of the glyoxylate shunt enzymes suggests that (in contrast to $E$. coli) acetate may be further metabolized in $Y$. pseudotuberculosis. Our data also indicate that the bloodstream environment can regulate major virulence genes (positively or negatively); the yadA adhesin gene and most of the transcriptional units of the pYV-encoded type III secretion apparatus were found to be upregulated, whereas transcription of the $\mathrm{pH} 6$ antigen locus was strongly repressed.

Conclusion: Our results suggest that plasma growth of $Y$. pseudotuberculosis is responsible for major transcriptional regulatory events and prompts key metabolic reorientations within the bacterium, which may in turn have an impact on virulence.
\end{abstract}




\section{Background}

The Gram-negative bacterium Y. pseudotuberculosis is a human enteropathogen which is able to cross the intestinal mucosa through the $M$ cells in Peyer's patches and thus infect the underlying tissues (causing ileitis and mesenteric lymphadenitis). However, in elderly or debilitated individuals (those suffering from malignancies, immunodeficiencies, chronic liver diseases or diabetes mellitus, for example), the organism frequently gains access to the bloodstream and can cause an often fatal septicemia $[1,2]$. Known Y. pseudotuberculosis virulence genes are transcriptionally regulated by temperature - most probably in order to adapt to the bacterium's life cycle outside and inside the host. Regulation by the omnipresent thermal stimulus can be modulated (via a wide range of mechanisms) by signals such as $\mathrm{pH}$, other ion concentrations and nutrient availability (reviewed in [3]). This allows bacterial pathogens to (i) adapt their gene transcription profiles in response to environmental cues sensed during the course of infection and (ii) express the most appropriate virulence factors at the expense of useless (or even detrimental) ones.

To date, the transcriptional gene regulation occurring when Y. pseudotuberculosis enters the human bloodstream has only been inferred indirectly from in vivo results in rodent models of infection $[4,5]$ and in vitro gene transcription studies. The in vitro regulation of certain Yersinia virulence loci has mainly been analyzed with respect to single growth parameter changes mimicking the environmental signals known (or assumed) to be detected by bacteria in blood, such as iron scarcity, oxygen tension and $\mathrm{pH}[6,7]$. In the present work, we have adopted an intermediate approach by comparing the overall gene expression profiles of $Y$. pseudotuberculosis grown in human plasma and in Luria-Bertani broth. We then compared the observed variations with those recently published for $Y$. pestis [8], an almost genetically identical pathogen which, however, causes plague - one of the most severe systemic infections in humans and other mammals.

\section{Results and discussion}

The genome of Y. pseudotuberculosis strain IP32953 has been recently deciphered: it contains 3,951 coding sequences (CDSs), of which 99 are borne by the virulenceassociated plasmid pYV and 43 are carried by a $27-\mathrm{kb}$ cryptic plasmid. Only around $49 \%$ of CDSs encode a product with a putative or proven function [9]. To gain insight into the transcriptional regulation of virulence and metabolism genes that takes place when Y. pseudotuberculosis enters and multiplies in the bloodstream, we compared the transcriptome of IP32953 grown in human plasma to the one of the same strain grown in Luria-Bertani (LB). To this end, we prepared macroarrays composed of 3,674 PCR fragments of $\approx 400$-base pairs (bp), covering 96\% of IP32953's CDSs and used them as described elsewhere [8] and in the Methods section. Briefly, in three independent cultures, total RNA was extracted from IP32953 cells grown in LB broth or human plasma, in the exponential or stationary phase and at $28^{\circ} \mathrm{C}$ or $37^{\circ} \mathrm{C}$. Macroarray probing was performed three times with independently retrotranscribed and $33 \mathrm{P}$-radiolabeled RNA samples from each of the eight growth combinations. After macroarray imaging, hybridization intensity data were log-transformed and normalized using a simple median normalization method. Relative data have been deposited in the Genoscript database http:// genodb.pasteur.fr/cgi-bin/WebObjects/GenoScript in accordance with standards of the Microarray Gene Expression Data Society (MGED). An analysis of variance (ANOVA) was carried out independently for each gene, with the three biological factors of variation (medium, temperature and growth phase) as fixed effects. This statistical approach allowed us to evaluate the transcriptional variations induced by each factor for the dataset as a whole. Thus, three ratios (corresponding to each parameter) and associated $p$-values were calculated for each gene. Inter-condition transcriptional differences were considered to be statistically significant if the $p$-value was below 0.05. Representative macroarray hybridization results were confirmed by qRT-PCR on stored RNA samples, using the constitutively expressed YPTB0775 gene (spot ID YPO3356 and coding for the outer membrane lipoprotein NplD) as a reference (Additional file 1). Since the physiological status of the bacterium during host infection is unknown, we focused our analysis on genes regulated by the temperature and/or the medium in both the exponential and stationary phases. All Y. pseudotuberculosis transcriptional variations discussed herein were compared with those of their respective $Y$. pestis orthologs and are summarized in Table 1. Y. pseudotuberculosis IP32953 genes regulated at the transcriptional level by growth temperature and/or medium are listed in Tables 2 and 3.

Free iron limitation is a well-known stimulus encountered by bacteria in plasma $[10,11]$. As expected, IP32953 genes required for iron storage (such as the ferritin-encoding gene ftnA [12] (Fig. 1)) were found to be downregulated in plasma. Transcriptional upregulation of most iron uptake systems (along with accessory protein-encoding genes tonB, exbB and exbD) (Fig. 1) is also consistent with this condition and is in agreement with the recent findings in Y. pestis [8]. As iron is used as a cofactor by numerous enzymes (mostly when complexed with sulfur), the metal is essential for a broad range of metabolic processes. Besides activation of iron homeostasis systems, lack of iron is also expected to be associated with a dramatic decrease in the transcription of genes encoding such enzymes, with the underlying goal of lowering iron consumption. This situation is exemplified by the katA gene 
Table I: Y. pseudotuberculosis transcriptional variations discussed in this article compared with those recently published for $Y$. pestis [8]

\begin{tabular}{|c|c|c|c|c|c|c|c|}
\hline \multicolumn{2}{|c|}{ Locus tags } & \multirow[b]{2}{*}{ Gene Name } & \multirow[b]{2}{*}{ Putative product/function } & \multicolumn{4}{|c|}{$\begin{array}{c}\text { gene transcription fold ratio human plasma/Luria Bertani broth } \\
(p-\text { value })\end{array}$} \\
\hline Y. pseudotuberculosis & Y. pestis & & & \multicolumn{2}{|c|}{ Y. pseudotuberculosis } & \multicolumn{2}{|c|}{ Y. pestis } \\
\hline \multicolumn{8}{|c|}{ Iron uptake and storage } \\
\hline YPTBI659 & YPOI783 & $f \operatorname{tn} A$ & ferritin & 0.180 & $(<0.001)$ & $0.34 I$ & $(0.001)$ \\
\hline YPTB0336 & YPO0279 & hmuV & $A B C$ hemin transporter, ATP-binding subunit $\mathrm{HmuV}$ & 1.665 & $(0.003)$ & 1.499 & $(0.021)$ \\
\hline YPTB0338 & YPO028I & hmuT & $A B C$ transporter, periplasmic hemin-binding protein $\mathrm{HmuT}$ & 1.684 & $(0.016)$ & 2.149 & $(0.001)$ \\
\hline YPTB0339 & YPO0282 & hmuS & possible hemin degradation/transport protein HmuS & 1.577 & $(0.022)$ & 1.984 & $(<0.001)$ \\
\hline YPTB0340 & YPO0283 & hmuR & TonB-dependent outer membrane hemin receptor, HmuR & 7.426 & $(<0.001)$ & 2.028 & $(<0.001)$ \\
\hline YPTB0739 & YPO3392 & fhuc & $\begin{array}{l}\text { putative } A B C \text { type hydroxymate-dependent iron transport ATP } \\
\text { binding protein }\end{array}$ & 1.932 & $(0.047)$ & 1.500 & $(0.258)$ \\
\hline YPTB0740 & YPO3391 & fhuD & $\begin{array}{l}\text { putative } A B C \text { type hydroxamate-dependent iron uptake ATP } \\
\text { binding protein }\end{array}$ & 1.836 & $(0.02 I)$ & 1.174 & $(0.486)$ \\
\hline YPTBI34I & YPOI310 & yiuA & $\begin{array}{l}\text { putative } A B C \text { type periplasmic iron siderophore/cobalamin binding } \\
\text { protein }\end{array}$ & 3.085 & $(<0.001)$ & 1.737 & $(0.027)$ \\
\hline YPTBI343 & YPOI3I2 & yiuc & $\begin{array}{l}\text { putative siderophore/cobalamin ABC transporter, ATP-binding } \\
\text { subunit }\end{array}$ & 2.468 & $(<0.00 \mathrm{I})$ & 1.991 & $(0.012)$ \\
\hline YPTBI5I2 & YPOI496 & & putative heme-binding protein & 2.456 & $(<0.001)$ & 0.921 & $(0.639)$ \\
\hline YPTB 1513 & YPOI497 & & putative $A B C$ transporter $A T P$-binding protein & 1.877 & $(0.009)$ & 1.408 & $(0.113)$ \\
\hline YPTBI5I5 & YPOI499 & & putative membrane protein & $1.52 \mathrm{I}$ & $(0.045)$ & 1.018 & $(0.921)$ \\
\hline YPTBI540 & YPOI528 & ysuF & putative ferric iron reductase & 4.019 & $(<0.001)$ & 3.137 & $(<0.001)$ \\
\hline YPTBI54I & YPOI529 & ysuJ & putative decarboxylase & 2.092 & $(<0.001)$ & 1.246 & $(0.236)$ \\
\hline YPTBI543 & YPOI53I & ysuH & putative siderophore biosynthetic enzyme & 1.896 & $(0.021)$ & 1.213 & $(0.387)$ \\
\hline YPTBI544 & YPOI532 & ysuG & putative siderophore biosynthetic enzyme & 2.403 & $(0.005)$ & 1.830 & $(0.006)$ \\
\hline YPTBI549 & YPOI537 & ysuR & putative OMR family iron-siderophore receptor & 2.610 & $(<0.001)$ & 3.273 & $(0.001)$ \\
\hline YPTB2II7 & YPO2193 & $\operatorname{ton} B$ & TonB protein & 5.464 & $(<0.001)$ & 2.563 & $(0.001)$ \\
\hline YPTB2347 & YPO2439 & $y f e A$ & $\begin{array}{l}A B C \text { transporter, periplasmic iron siderophore-binding protein } \\
Y f e A\end{array}$ & 11.88 & $(<0.001)$ & 10.22 & $(<0.001)$ \\
\hline YPTB2348 & YPO2440 & yfeB & $A B C$ chelated iron transporter, $A T P$-binding subunit $Y f e B$ & 3.141 & $(<0.001)$ & 2.772 & $(0.001)$ \\
\hline YPTB2349 & YPO244I & yfeC & $A B C$ chelated iron transporter, permease subunit $Y f e C$ & 4.375 & $(<0.001)$ & 1.817 & $(0.017)$ \\
\hline YPTB2350 & YPO2442 & yfeD & $A B C$ chelated iron transporter, permease subunit $Y f e D$ & 2.103 & $(<0.001)$ & 1.369 & $(0.195)$ \\
\hline YPTB2353 & YPO2445 & yfeE & putative yfe $A B C D$ locus regulator & 1.527 & $(0.008)$ & 2.085 & $(0.001)$ \\
\hline YPTB3263 & YPO0989 & iucA & possible siderophore biosynthesis protein, lucA familly & 3.789 & $(<0.001)$ & 2.059 & $(0.033)$ \\
\hline YPTB3265 & YPO0992 & iucC & putative siderophore biosynthesis protein lucC & 2.600 & $(<0.001)$ & 0.920 & $(0.7 I I)$ \\
\hline YPTB3266 & YPO0993 & iucD & putative siderophore biosynthesis protein lucD & 2.151 & $(0.002)$ & 0.631 & $(0.036)$ \\
\hline YPTB3298 & YPOIOII & & $\begin{array}{l}\text { putative TonB-dependent O-M, iron siderophore receptor/ } \\
\text { tranporter }\end{array}$ & 2.150 & $(0.005)$ & 1.845 & $(0.018)$ \\
\hline YPTB3383 & YPO0682 & exbB & possible MotA/TolQ/ExbB proton channel family protein & 4.165 & $(<0.001)$ & 3.021 & $(<0.001)$ \\
\hline YPTB3382 & YPO0683 & exbD & pExbD/TolR-family transport protein & $9.8 \mathrm{II}$ & $(<0.001)$ & 3.576 & $(<0.001)$ \\
\hline YPTB370I & YPO0205 & $b f d$ & putative bacterioferritin-associated ferredoxin & 1.857 & $(0.002)$ & 3.195 & $(<0.001)$ \\
\hline YPTB3700 & YPO0206 & $b f r$ & bacterioferritin & 1.153 & $(0.255)$ & 4.483 & $(<0.001)$ \\
\hline YPTB3767 & YPOOI33 & feoA & conserved hypothetical protein & 1.510 & $(0.046)$ & 1.081 & $(0.648)$ \\
\hline YPTB3769 & YPO0I3I & $\mathrm{feoC}$ & conserved hypothetical protein & 1.900 & $(0.001)$ & 1.964 & $(0.002)$ \\
\hline YPTB3857 & YPO4022 & & $\begin{array}{l}\text { putative } A B C \text { transporter, periplasmic iron siderophore } \\
\text { ferrichrome binding protein }\end{array}$ & 3.127 & $(<0.001)$ & 2.157 & $(<0.001)$ \\
\hline YPTB3858 & YPO4023 & & putative $A B C$ iron siderophore transporter, permease subunit & 2.236 & $(0.001)$ & 1.214 & $(0.529)$ \\
\hline YPTB3860 & YPO4025 & & putative $A B C$ iron siderophore transporter, ATP-binding subunit & 2.216 & $(0.001)$ & 1.417 & $(0.04 I)$ \\
\hline YPTBI246 & YPOI 207 & katA & putative catalase & 0.324 & $(<0.001)$ & 0.556 & $(0.002)$ \\
\hline
\end{tabular}


Table I: Y. pseudotuberculosis transcriptional variations discussed in this article compared with those recently published for Y. pestis [8] (Continued)

\begin{tabular}{|c|c|c|c|c|c|c|c|}
\hline YPTB08II & YPO3319 & katY & putative catalase-hydroperoxidase HPII & 0.603 & $(0.009)$ & 0.717 & $(0.342)$ \\
\hline \multicolumn{8}{|l|}{ Biotin operon } \\
\hline YPTBII8I & YPOII50 & bioA & $\begin{array}{l}\text { putative adenosylmethionine-8-amino-7-oxononanoate } \\
\text { aminotransferase }\end{array}$ & 3.377 & $(<0.001)$ & 2.512 & $(0.002)$ \\
\hline YPTBII 83 & YPOII52 & biof & putative 8-amino-7-oxononanoate synthase & 3.800 & $(<0.001)$ & 2.595 & $(<0.001)$ \\
\hline YPTBII 84 & YPOII53 & bioc & putative biotin synthesis protein $\mathrm{BioC}$ & 1.784 & $(0.004)$ & 1.351 & $(0.374)$ \\
\hline YPTB 185 & YPOII54 & bioD & putative dethiobiotin synthetase & 2.499 & $(0.002)$ & 1.780 & $(0.026)$ \\
\hline \multicolumn{8}{|c|}{ Superoxyde dismutases } \\
\hline YРTB3925 & YPO406I & sodA & putative superoxide dismutase [Mn] & 3.101 & $(<0.001)$ & 1.796 & $(0.049)$ \\
\hline YPTB2299 & YPO2386 & $\operatorname{sod} B$ & superoxide dismutase $[\mathrm{Fe}]$ & 0.090 & $(<0.001)$ & 0.326 & $(<0.001)$ \\
\hline \multicolumn{8}{|c|}{ Ribonucleotides reductases (RNR) } \\
\hline YPTB2956 & YPO2650 & nrdl & probable Nrdl protein homologue & 2.842 & $(0.001)$ & 8.784 & $(<0.001)$ \\
\hline YPTB2957 & YPO2649 & nrdE & putative ribonucleoside-diphosphate reductase 2 alpha chain & 4.745 & $(<0.001)$ & 9.007 & $(<0.001)$ \\
\hline YPTB2958 & YPO2648 & $n r d F$ & putative ribonucleoside-diphosphate reductase 2 beta chain & 2.672 & $(0.002)$ & 2.142 & $(0.011)$ \\
\hline YPTB2955 & YPO265I & $n r d H$ & putative glutaredoxin & 1.407 & $(0.152)$ & 3.439 & $(<0.001)$ \\
\hline YPTB।254 & YPOI214 & $n r d A$ & putative ribonucleoside-diphosphate reductase I alpha chain & 0.329 & $(<0.001)$ & 0.668 & $(0.085)$ \\
\hline YPTBI253 & YPOI213 & $\operatorname{nrdB}$ & putative ribonucleoside-diphosphate reductase I beta chain & 0.815 & $(0.35 \mathrm{I})$ & 0.579 & $(0.020)$ \\
\hline YPTB0519 & YPO3454 & $\operatorname{nrdD}$ & putative anaerobic ribonucleoside-triphosphate reductase & 0.614 & $(0.025)$ & 0.373 & $(<0.001)$ \\
\hline YPTB0518 & YPO3455 & $\operatorname{nrdG}$ & putative anaerobic ribonucleotide reductase activating protein & 0.440 & $(0.001)$ & 0.508 & $(0.019)$ \\
\hline \multicolumn{8}{|c|}{ Mannose and glucose uptake } \\
\hline YPTBI634 & YPOI758 & $\operatorname{man} X$ & probable PTS system, mannose-specific IIAB component & 2.673 & $(<0.001)$ & 3.234 & $(<0.001)$ \\
\hline YPTBI633 & YPOI757 & $\operatorname{man} Y$ & probable PTS system, mannose-specific IIC component & 1.991 & $(0.006)$ & 2.201 & $(<0.001)$ \\
\hline YPTB। 632 & YPOI756 & $\operatorname{man} Z$ & probable PTS system, mannose-specific IID component & 3.084 & $(<0.001)$ & 3.676 & $(<0.001)$ \\
\hline YPTB2463 & YPOI608 & ptsG, & putative PTS system, glucose-specific IIBC component & 4.033 & $(<0.001)$ & 1.708 & $(0.027)$ \\
\hline YPTB27I5 & YPO2993 & $\mathrm{ptsH}$ & probable PTS system, phosphocarrier protein & 1.697 & $(0.002)$ & 1.422 & $(0.109)$ \\
\hline YPTB2716 & YPO2994 & ptsl & putative PTS sytem, enzyme I component & 1.946 & $(<0.001)$ & 1.351 & $(0.038)$ \\
\hline YPTB27I7 & YPO2995 & $\mathrm{crr}$ & putative PTS system, glucose-specific IIA component, permease & 1.611 & $(0.002)$ & 1.440 & $(0.117)$ \\
\hline \multicolumn{8}{|c|}{ Sugar metabolism } \\
\hline YPTB0074 & YPO0078 & $p f k A$ & putative 6-phosphofructokinase & 1.594 & $(0.017)$ & 1.430 & $(0.073)$ \\
\hline YPTB3।95 & YPO0920 & $f b a A, f b a, f d a$ & possible fructose-bisphosphate aldolase class II & 1.325 & $(0.049)$ & 1.504 & $(0.104)$ \\
\hline YPTB3196 & YPO0921 & pgk & putative phosphoglycerate kinase & 1.365 & $(0.024)$ & 1.365 & $(0.099)$ \\
\hline YPTBII66 & YPOII33 & gpmA, gpm & putative phosphoglycerate mutase I & 3.179 & $(<0.001)$ & 3.650 & $(<0.001)$ \\
\hline YPTB2047 & YPO2064 & pykA & putative pyruvate kinase II & 0.486 & $(0.00 \mathrm{I})$ & 0.604 & $(0.013)$ \\
\hline YPTB2306 & YPO2393 & pykF & probable pyruvate kinase I & 2.282 & $(<0.001)$ & 1.322 & $(0.185)$ \\
\hline YPTB3762 & YPO0I38 & pck & putative phosphoenolpyruvate carboxykinase [ATP] & 0.395 & $(0.001)$ & 1.213 & $(0.460)$ \\
\hline YPTB2I 03 & YPO2180 & adhE, ana & putative aldehyde-alcohol dehydrogenase & 2.116 & $(0.001)$ & 3.383 & $(<0.001)$ \\
\hline YPTB0460 & YPO35I6 & $m d h$ & putative malate dehydrogenase & 0.665 & $(0.010)$ & 0.394 & $(<0.001)$ \\
\hline YPTB0796 & YPO3335 & fumA, fumB & putative fumarase $\mathrm{A}$ fumarate hydratase class $\mathrm{I}$, aerobic isozyme & $0.35 I$ & $(<0.001)$ & 0.501 & $(0.020)$ \\
\hline YPTB04I3 & YPO0360 & frdA & putative fumarate reductase flavoprotein subunit & 0.156 & $(<0.001)$ & 0.299 & $(<0.00 \mathrm{I})$ \\
\hline YPTB04I2 & YPO0359 & $f r d B$ & putative fumarate reductase iron-sulfur protein & 0.127 & $(<0.001)$ & 0.217 & $(<0.001)$ \\
\hline YPTB04II & YPO0358 & frdC & putative fumarate reductase hydrophobic protei & 0.248 & $(<0.001)$ & 0.403 & $(<0.001)$ \\
\hline YPTB04I0 & YPO0357 & frdD & putative fumarate reductase hydrophobic protein & 0.393 & $(0.001)$ & 0.372 & $(<0.001)$ \\
\hline YPTBII 45 & YPOIIII & $\operatorname{sch} A$ & putative succinate dehydrogenase flavoprotein subunit & 0.497 & $(<0.001)$ & 0.124 & $(<0.001)$ \\
\hline YPTB। I 44 & YPOIIIO & $s d h D$ & $\begin{array}{l}\text { Putative succinate dehydrogenase hydrophobic membrane anchor } \\
\text { protein }\end{array}$ & 0.501 & $(<0.001)$ & 0.165 & $(<0.001)$ \\
\hline YPTBII43 & YPOII09 & sdhC & putative succinate dehydrogenase cytochrome b-556 subunit & 0.553 & $(0.016)$ & 0.241 & $(0.00 I)$ \\
\hline YPTBII46 & YPOIII2 & $\operatorname{sdh} B$ & putative succinate dehydrogenase iron-sulfur protein & 0.592 & $(0.004)$ & 0.196 & $(<0.001)$ \\
\hline YPTBII49 & YPOIII5 & succ & putative succinyl-CoA synthetase beta chain & 0.419 & $(<0.001)$ & 0.205 & $(<0.001)$ \\
\hline YPTBIII50 & YPOIII6 & SucD & putative succinyl-CoA synthetase alpha chain & 0.525 & $(<0.001)$ & 0.236 & $(0.001)$ \\
\hline YPTBII48 & YPOIII4 & sucB & putative dihydrolipoamide succinyltransferase component & 0.610 & $(0.014)$ & 0.267 & (0.003) \\
\hline
\end{tabular}


Table I: Y. pseudotuberculosis transcriptional variations discussed in this article compared with those recently published for Y. pestis [8] (Continued)

\begin{tabular}{|c|c|c|c|c|c|c|c|}
\hline YPTBII47 & YPOIII3 & SucA & putative 2-oxoglutarate dehydrogenase EI component & 0.516 & $(0.007)$ & 0.193 & $(<0.001)$ \\
\hline YPTB07I6 & YPO34I5 & $a c n B$ & putative aconitate hydratase 2 & 0.510 & $(<0.001)$ & 0.319 & $(<0.001)$ \\
\hline YPTB3656 & YPO3725 & aceA, icl & isocitrate lyase & 2.068 & $(0.003)$ & 1.298 & $(0.319)$ \\
\hline YPTB3657 & YPO3726 & aceB, mas & malate synthase $A$ & 1.875 & $(0.053)$ & 1.089 & $(0.710)$ \\
\hline YPTB2222 & YPO2300 & fnr, nirR & putative fumarate and nitrate reduction regulatory protein & 0.699 & $(0.002)$ & 0.877 & $(0.621)$ \\
\hline YPTB060I & YPO0458 & $\operatorname{arcA}$ & $\begin{array}{l}\text { probable response regulator } \\
\text { (OmpR family) }\end{array}$ & 0.464 & $(0.001)$ & 0.705 & $(0.036)$ \\
\hline \multicolumn{8}{|l|}{ Porins } \\
\hline YPTBI964 & YPOI4II & ompC2 & putative outer membrane protein $\mathrm{C} 2$, porin & 0.835 & $(0.447)$ & 1.827 & $(0.001)$ \\
\hline YPTBI26I & YPOI222 & ompC & putative outer membrane protein $\mathrm{C}$, porin & 0.285 & $(<0.001)$ & 0.659 & $(0.013)$ \\
\hline YPTBI453 & YPOI435 & ompA & putative outer membrane porin A protein & 1.085 & $(0.372)$ & 0.587 & $(0.070)$ \\
\hline \multicolumn{8}{|c|}{ Chromosomal virulence factors } \\
\hline YPTBI668 & YPO3944 & inv & putative invasin & $0.50 \mathrm{I}$ & $(<0.001)$ & 0.993 & $(0.976)$ \\
\hline YPTBI334 & YPOI303 & psaA & $\mathrm{pH} 6$ antigen precursor & & $(<0.001)$ & 0.367 & $(0.154)$ \\
\hline YPTB। 335 & YPOI304 & psaB & chaperone protein PsaB precursor & 0.216 & $(<0.001)$ & 0.700 & $(0.214)$ \\
\hline YPTB।332 & YPOI30I & psaE & putative regulatory protein & 1.987 & $(0.002)$ & 2.619 & $(<0.001)$ \\
\hline \multicolumn{8}{|c|}{ pYV-encoded virulence factors - Type Three Secretion System } \\
\hline pYV0062 & YPCDI.36c & yscX & YscX, putative type III secretion protein & 1.629 & $(0.009)$ & 0.873 & $(0.444)$ \\
\hline PYV00I4 & YPCDI.89 & & possible transposase remnant (pseudogene) & 1.789 & $(0.025)$ & 0.786 & $(0.899)$ \\
\hline pYV0076 & YPCDI.49 & IcrF & LcrF, VirF; putative thermoregulatory protein & 1.441 & $(0.042)$ & 1.311 & $(0.216)$ \\
\hline pYV0058 & YPCDI.32c & IcrG & LcrG, putative Yop regulator & 1.713 & $(0.014)$ & $0.94 I$ & $(0.853)$ \\
\hline pYV0056 & YPCDI.30c & $\mathrm{IcrH}$, sycD & $\mathrm{LcrH}$, SycD; low calcium response protein $\mathrm{H}$ & 3.522 & $(<0.001)$ & 0.898 & $(0.480)$ \\
\hline pYV0059 & YPCDI.33c & IcrR & LcrR, hypothetical protein & 1.469 & $(0.001)$ & 0.700 & $(0.129)$ \\
\hline pYV0057 & YPCDI.3Ic & IcrV & LcrV, putative $V$ antigen, antihost protein/regulator & 1.904 & $(<0.001)$ & 1.302 & $(0.051)$ \\
\hline pYV0024 & YPCDI.05c & sycE & SycE, yerA; putative yopE chaperone & 5.781 & $(<0.001)$ & 1.344 & $(0.165)$ \\
\hline pYV0020 & YPCDI.95c & sych & SycH, putative yopH targeting protein & 5.088 & $(<0.001)$ & 2.029 & $(0.002)$ \\
\hline pYV00I7 & YPCDI.91 & & putative resolvase & 0.341 & $(<0.001)$ & 1.152 & $(0.705)$ \\
\hline pYV0075 & YPCDI.48 & virG & VirG; putative Yop targeting lipoprotein & 1.957 & $(0.015)$ & 1.544 & $(0.023)$ \\
\hline pYV0055 & YPCDI.29c & yopB & YopB, putative Yop targeting protein & 2.816 & $(<0.001)$ & 0.956 & $(0.758)$ \\
\hline pYV0054 & YPCDI.28c & yopD & YopD, putative Yop negative regulation/targeting component & 2.933 & $(<0.00 \mathrm{I})$ & 0.950 & $(0.833)$ \\
\hline pYV0047 & YPCDI.26c & уорм & YopM, putative targeted effector protein & 3.467 & $(<0.001)$ & 1.044 & $(0.845)$ \\
\hline pYV0065 & YPCDI.39c & yopN & YopN, LcrE; putative membrane-bound Yop targeting protein & 2.612 & $(<0.001)$ & 0.878 & $(0.475)$ \\
\hline pYV0078 & YPCDI.5I & & hypothetical protein & 3.037 & $(0.002)$ & 1.056 & $(0.716)$ \\
\hline pYV0079 & YPCDI.52 & yscC & YscC, putative type III secretion protein & 2.383 & $(0.001)$ & 0.715 & $(0.221)$ \\
\hline pYV0080 & YPCDI.53 & $y s c D$ & YscD, putative type III secretion protein & $2.54 I$ & $(<0.001)$ & 0.715 & $(0.095)$ \\
\hline pYV008I & YPCDI.54 & yscE & YscE, putative type III secretion protein & 2.710 & $(0.001)$ & 0.543 & $(0.056)$ \\
\hline pYV0082 & YPCDI.55 & yscF & YscF, putative type III secretion protein & 2.116 & $(0.017)$ & 0.616 & $(0.135)$ \\
\hline pYV0083 & YPCDI.56 & yscG & YscG, putative type III secretion protein & 2.462 & $(<0.001)$ & 0.905 & $(0.595)$ \\
\hline pYV0085 & YPCDI.58 & yscl & Yscl, LcrO; putative type III secretion protein & 1.864 & $(0.003)$ & 1.024 & $(0.906)$ \\
\hline pYV0089 & YPCDI.62 & yscM, IcrQ & YscM, LcrQ, putative type III secretion regulatory & 0.678 & $(0.036)$ & 0.755 & $(0.052)$ \\
\hline pYV0067 & YPCDI.40 & & putative Yops secretion ATP synthase & 2.855 & $(<0.001)$ & $0.97 \mathrm{I}$ & $(0.886)$ \\
\hline pYV0068 & YPCDI.4I & yscO & YscO, putative type III secretion protein & 3.087 & $(<0.001)$ & 0.974 & $(0.913)$ \\
\hline pYV0070 & YPCDI.43 & $y s c Q$ & YscQ, putative type III secretion protein & 1.635 & $(0.026)$ & 1.214 & $(0.430)$ \\
\hline PYV007I & YPCDI.44 & $y s c R$ & YscR, putative Yop secretion membrane protein & 1.948 & $(0.012)$ & 1.296 & $(0.269)$ \\
\hline pYV0072 & YPCDI.45 & yscS & YscS, putative type III secretion protein & $2.33 I$ & $(<0.001)$ & 1.218 & $(0.280)$ \\
\hline \multicolumn{8}{|c|}{ pYV-encoded virulence factors - Others } \\
\hline pYV00I3 & YPCDI.88c & yadA & YadA, Yersinia adhesion & 13.52 & $(<0.001)$ & 1.040 & $(0.861)$ \\
\hline
\end{tabular}


Table 2: Y. pseudotuberculosis IP32953 chromosomal genes (sorted by COG class [28]) that are transcriptionally regulated by growth medium and/or temperature.

\begin{tabular}{llcl}
\hline COG class Gene designation & $\begin{array}{c}\text { Genoscript } \\
\text { spot ID }\end{array}$ & Gene product/function & Fold ratio in gene transcription ( $p$-value)
\end{tabular}

Human plasma/Luria Bertani Broth

$37^{\circ} \mathrm{C} / 28^{\circ} \mathrm{C}$

C: energy production and conversion

YPTBO0 and con

YPTB0I08 (PPC)

YPO0090

glycerol kinase

0.437

$(0.002)$

YPTBOII8

YPO3917

phosphoenolpyruvate carboxylase

oxidoreductase

YPTB02II $(g \mid p C$

YPO3824

anaerobic glycerol-3-phosphate dehydrogenase

subunit $C$

YPTB0374 (qor)

YPTB04 10 ( frdD)

YPO0319

YPTB04II ( $f r d C$ )

YPO0357

quinone oxidoreductase

fumarate reductase hydrophobic protein

YPTB04I2 (frdB)

YPTB04I3 (frdA)

YPTB0460 ( $\mathrm{mdh}$ )

YPTB07I4 (aceF)

YPO0359

YPO0360

fumarate reductase hydrophobic protein

fumarate reductase iron-sulfur protein

fumarate reductase flavoprotein subunit

malate dehydrogenase

pyruvate dehydrogenase.

pyruvate dehydrogenase.
dihydrolipoyltransacetylase component

YPTB07I5 (IDdA) YPO34I7 dihydrolipoamide dehydrogenase component of pyruvate dehydrogenase complex

YPTB0716 (acnB)

YPTB0796 (fumA)

YPTB0887 (nqrA)

YPTB0888 (nqrB)

aconitate hydratase 2

YPO3415

YPO3335

fumarate hydratase. class I

YPO3240 NADH-ubiquinone oxidoreductase subunit A

YPO3239

$\mathrm{NADH}$-ubiquinone oxidoreductase subunit $\mathrm{B}$

$\mathrm{Na}$-translocating $\mathrm{NADH}$-quinone reductase

subunit c

YPTB0892 (nqrF)

YPTB0895

YPTB0949 (cyoD)

YPTB0952 (cyoA)

YPTBII 25 (fldA)

YPTBII43 (sdhC)

YPTBI $144(s d h D)$

YPTBI 145 (sdhA)

YPTBI I 46 (sdhB)

YPTBI 147 (sucA)

YPTBI I 48 (sucB)

YPO3235

YPO3232

YPO3167

$\mathrm{NADH}$-uniquinone oxidoreductase subunit $\mathrm{F}$

putative exported protein

cytochrome $\mathrm{O}$ ubiquinol oxidase subunit $\mathrm{CyoD}$

YPO3164

YPO2635

cytochrome $\mathrm{O}$ ubiquinol oxidase subunit II

flavodoxin I

YPOII09 succinate dehydrogenase cytochrome b-556

subunit

YPOIIIO succinate dehydrogenase hydrophobic membrane anchor protein

YPOIIII succinate dehydrogenase flavoprotein subunit

YPOIII2 succinate dehydrogenase iron-sulfur protein

YPOIII3 2-oxoglutarate dehydrogenase El component

YPTBII49 (sucC)

YPTBII50 (sucD)

YPOIII4

dihydrolipoamide succinyltransferase component of 2-oxoglutarate dehydro

YPOIII5

YPOIII6

succinyl-CoA synthetase beta chain

1.393

1.393
0.393

0.248

0.128

0.157

0.665

$0.543 \quad(<0.001)$

$0.676 \quad(0.03)$

YPTBII5I (cydA)

YPOIII7

succinyl-CoA synthetase alpha chain

YPTBI I 52 (cydB)

YPOIII8

cytochrome $D$ ubiquinol oxidase subunit I

cytochrome $D$ ubiquinol oxidase subunit II

$\begin{array}{lc}0.5 I & (<0.00 I) \\ 0.35 I & (<0.00 I) \\ 0.328 & (<0.00 I) \\ 0.58 & (0.002) \\ 0.551 & (0.021) \\ 0.66 I & (0.044) \\ & \\ 0.537 & (<0.00 I) \\ 0.552 & (0.015) \\ & \\ 0.5 & (<0.00 I) \\ 0.497 & (<0.00 I) \\ 0.592 & (0.003) \\ 0.515 & (0.006) \\ 0.61 & (0.013) \\ 0.419 & (<0.00 I) \\ 0.524 & (<0.00 I) \\ 0.442 & (<0.001) \\ 0.565 & (0.004)\end{array}$

0.657

$0.492 \quad(<0.001)$

I.5I8 (0.049)

$(0.001)$

.044)

$\begin{array}{ll}0.6 & (0.008) \\ 0.534 & (0.001)\end{array}$

$0.516 \quad(<0.001)$

$\begin{array}{ll}0.516 & (<0.001) \\ 0.722 & (0.033)\end{array}$

$0.622 \quad(0.045)$

$0.654 \quad(0.014)$

0.671

$(0.04)$

0.001)

$(0.004)$ 


\begin{tabular}{|c|c|c|c|c|c|c|}
\hline YPTBI408 (pflB) & YPOI383 & formate acetyltransferase I & 0.462 & $(<0.00 \mathrm{I})$ & I.9II & $(<0.00 \mathrm{I})$ \\
\hline YPTBI723 (putA) & YPOI85I & $\begin{array}{l}\text { bifunctional PutA protein [includes: proline } \\
\text { dehydrogenase and delta-I-p }\end{array}$ & 0.643 & $(<0.00 \mathrm{I})$ & 0.642 & $(<0.001)$ \\
\hline YPTB।945 & YPOI947 & putative thioredoxin & 1.646 & $(0.002)$ & & \\
\hline YPTB20I2 & YPO2028 & putative exported protein & & & 0.6 & $(0.008)$ \\
\hline YPTB20I7 & YPO2035 & hypothetical protein & 1.694 & $(0.045)$ & & \\
\hline YPTB2089 & YPO2163 & putative nitroreductase & 2.095 & $(<0.00 \mathrm{I})$ & & \\
\hline YPTB2 103 (adhE) & YPO2180 & aldehyde-alcohol dehydrogenase & 2.115 & $(<0.001)$ & & \\
\hline YPTB2165 & YPO2244 & Fe-S binding NADH dehydrog. (pseudogene. F/S) & & & 2.157 & $(<0.00 \mathrm{I})$ \\
\hline YPTB2224 (pntB) & YPO2302 & NAD(P) transhydrogenase subunit beta & & & 1.502 & $(0.037)$ \\
\hline YPTB2248 (IdhA) & YPO2329 & D-lactate dehydrogenase & 0.615 & $(0.006)$ & & \\
\hline YPTB2253 (niff) & YPO2334 & putative pyruvate-flavodoxin oxidoreductase & & & 1.697 & $(0.014)$ \\
\hline YPTB2427 (icdA) & YPOI64I & isocitrate dehydrogenase [NADP] & & & 0.632 & $(0.013)$ \\
\hline YPTB2529 & YPO2492 & putative dioxygenase beta subunit & 0.535 & $(0.02)$ & & \\
\hline YPTB2578 (nuoK) & or3622 & NADH dehydrogenase i chain $\mathrm{k}$ & 0.642 & $(0.001)$ & & \\
\hline YPTB258I (nuoH) & YPO2549 & $\mathrm{NADH}$ dehydrogenase I chain $\mathrm{H}$ & 0.745 & $(0.023)$ & & \\
\hline YPTB2585 (nuoD) & YPO2553 & NADH dehydrogenase I chain C/D & 0.573 & $(0.003)$ & & \\
\hline YPTB2587 (nuoA) & YPO2555 & NADH dehydrogenase I chain A & 0.62 & $(<0.001)$ & & \\
\hline YPTB2597 (ackA) & YPO2566 & acetate kinase & 0.652 & $(0.001)$ & & \\
\hline YPTB2598 (pta) & YPO2567 & phosphate acetyltransferase & 0.667 & $(0.017)$ & & \\
\hline YPTB2689 (dmsB) & YPO2966 & $\begin{array}{l}\text { putative dimethyl sulfoxide reductase chain B } \\
\text { protein }\end{array}$ & 0.598 & $(0.031)$ & & \\
\hline YPTB2703 & YPO2980 & putative ion channel protein & 0.565 & $(0.01)$ & & \\
\hline YPTB2758 (napC) & YPO3036 & cytochrome C-type protein NapC & & & 0.636 & $(0.015)$ \\
\hline YPTB3469 (fadH) & YPO0589 & 2.4-dienoyl-CoA reductase & 0.465 & $(0.002)$ & 1.713 & $(0.024)$ \\
\hline YPTB3539 & YPO3694 & putative cytochrome & & & 0.544 & $(<0.001)$ \\
\hline YРTB3592 & YPO3637 & putative carbohydrate kinase & & & 1.585 & $(0.031)$ \\
\hline YPTB3656 (aceA) & YPO3725 & isocitrate lyase & 2.069 & $(0.002)$ & 1.963 & $(0.004)$ \\
\hline YPTB3762 (pckA) & YPO0I38 & phosphoenolpyruvate carboxykinase [ATP] & 0.395 & $(0.001)$ & & \\
\hline YPTB3782 (glpD) & YPO3937 & aerobic glycerol-3-phosphate dehydrogenase & 0.409 & $(0.02)$ & & \\
\hline YPTB3927 (fdoG) & or2536 & formate dehydrogenase-O. major subunit & 0.208 & $(<0.00 \mathrm{I})$ & 0.712 & $(0.029)$ \\
\hline YPTB3928 (fdoH) & YPO4057 & formate dehydrogenase-O. iron-sulfur subunit & 0.187 & $(<0.001)$ & 0.698 & $(0.03)$ \\
\hline YPTB3929 (fdol) & YPO4056 & $\begin{array}{l}\text { formate dehydrogenase. cytochrome b556 } \\
\text { protein }\end{array}$ & 0.372 & $(<0.001)$ & 0.551 & $(<0.001)$ \\
\hline YPTB3967 (atpD) & YPO4I2I & ATP synthase beta subunit protein & & & 0.679 & $(0.025)$ \\
\hline YPTB3968 (atpG) & YPO4I22 & ATP synthase gamma subunit protein & & & 0.658 & $(0.011)$ \\
\hline YPTB3970 (atpH) & or 2565 & ATP synthase delta subunit protein & & & 0.7 & $(0.005)$ \\
\hline YPTB397। (atpF) & YPO4I 25 & ATP synthase subunit $B$ protein & & & 0.616 & $(0.002)$ \\
\hline YPTB3972 (atpE) & or2563 & ATP synthase subunit $C$ protein & & & 0.656 & $(0.037)$ \\
\hline YPTB3973 (atpB) & YPO4I27 & ATP synthase subunit $B$ protein & 0.667 & $(0.004)$ & 0.732 & $(0.021)$ \\
\hline \multicolumn{7}{|c|}{ D: cell division and chromosome partitioning } \\
\hline YPTB0222 (ftsE) & YPO38I3 & cell division ATP-binding protein & & & 0.595 & $(0.019)$ \\
\hline YPTB। 430 (mukB) & YPOI405 & cell division protein & & & 0.62 & $(0.006)$ \\
\hline YPTB2923 & YPO2686 & putative membrane protein & 0.358 & $(<0.001)$ & & \\
\hline YPTB3126 & or3195 & possible bacteriophage protein & 1.616 & $(0.029)$ & & \\
\hline YPTB3976 (gidA) & YPO4I30 & glucose inhibited division protein $\mathrm{A}$ & 0.607 & $(0.007)$ & & $(0.007)$ \\
\hline
\end{tabular}




\begin{tabular}{|c|c|c|}
\hline YPTB0003 (asnA) & YPO0003 & aspartate-ammonia ligase \\
\hline YPTB0024 (glnA) & YPO0024 & glutamine synthetase \\
\hline YPTB0057 (tdh) & YPO0060 & threonine 3-dehydrogenase \\
\hline YPTB0066 (cysE) & YPO0070 & serine acetyltransferase \\
\hline YPTB0I06 (metL) & YPO0II6 & $\begin{array}{l}\text { bifunctional aspartokinase/homoserine } \\
\text { dehydrogenase II }\end{array}$ \\
\hline YPTB0III (argB) & YPO3925 & acetylglutamate kinase \\
\hline YPTBOI I 2 (argH) & YPO3924 & putative argininosuccinate lyase \\
\hline YPTBO I 34 (ilvG) & YPO390I & acetolactate synthase isozyme II large subunit \\
\hline YPTB0203 (rhtC) & YPO3832 & threonine efflux protein \\
\hline YPTB02 10 (glpB) & YPO3825 & $\begin{array}{l}\text { putative anaerobic glycerol-3-phosphate } \\
\text { dehydrogenase subunit B }\end{array}$ \\
\hline YPTB0226 (livK) & YPO3808 & branched-chain amino acid-binding protein \\
\hline YPTB0245 & or0170 & conserved hypothetical protein \\
\hline YPTB0248 (metE) & YPO3788 & $\begin{array}{l}\text { 5-methyltetrahydropteroyltriglutamate - } \\
\text { homocystei ne methyltransferase }\end{array}$ \\
\hline YPTB0345 & YPO0287 & putative methylenetetrahydrofolate reductase \\
\hline YPTB0402 (aspA) & YPO0348 & aspartate ammonia-lyase \\
\hline YPTB0407 & YPO0353 & conserved hypothetical protein \\
\hline YPTB052I & YPO3452 & $\begin{array}{l}\text { putative } A B C \text { transporter transporter. ATP- } \\
\text { binding protein }\end{array}$ \\
\hline YPTB0524 & YPO3448 & $\begin{array}{l}\text { (7G) putative extracellular solute-binding protein } \\
\text { (pseudogene. F/S) }\end{array}$ \\
\hline YРTB0557 & or039l & possible conserved cysteine desulfurase \\
\hline PTB0602 (arcA) & YPO0459 & aerobic respiration control protein \\
\hline YPTB0604 (thrB) & YPO046I & homoserine kinase \\
\hline YPTB0623 (carA) & YPO048I & carbamoyl-phosphate synthase small chain \\
\hline YPTB0624 (carB) & YPO0482 & carbamoyl-phosphate synthase large chain \\
\hline YPTB0676 (ilvH) & YPO0540 & acetolactate synthase isozyme III small subunit \\
\hline YPTB07II (aroP) & YPO342I & aromatic amino acid transport protein \\
\hline YPTB076I (cysH) & YPO3370 & $\begin{array}{l}\text { phosphoadenosine phosphosulfate reductase } \\
\text { (pseudogene. F/S) }\end{array}$ \\
\hline YРTB0789 & YPO3343 & probable extracellular solute-binding protein \\
\hline YPTB09II (aroL) & YPO32I5 & shikimate kinase II \\
\hline YPTB0920 (brnQ) & YPO3202 & $\begin{array}{l}\text { branched-chain amino acid transport system II } \\
\text { carrier protein }\end{array}$ \\
\hline YPTB। I $08(g \ln H)$ & YPO26I5 & putative amino acid-binding protein precursoR \\
\hline YPTB। I 86 & YPOII55 & putative amino acid transporteR \\
\hline YPTB 1240 & YPOI 200 & putative amino acid permease \\
\hline YPTBI24I & YPOI20I & putative amino acid decarboxylase \\
\hline YPTB।346 & YPOI3I5 & putative hydrolase (pseudogene. stop) \\
\hline YPTB। 352 (sdaC) & YPOI32I & serine transporteR \\
\hline YPTB। 362 (potG) & YPOI332 & putrescine transport ATP-binding protein \\
\hline YPTB। 375 (artM) & YPOI349 & arginine transport system permease protein \\
\hline YPTBI384 (рохB) & YPOI358 & Pyruvate dehydrogenase [cytochrome] \\
\hline YPTBI4II (ansB) & YPOI386 & putative L-asparaginase II precursoR \\
\hline YPTB। 434 (aspC) & YPOI4IO & aspartate aminotransferase \\
\hline
\end{tabular}

$\begin{array}{lccc}0.49 & (<0.00 I) & 1.531 & (0.042) \\ 0.663 & (0.04 I) & 0.448 & (<0.001) \\ 1.669 & (0.016) & & \\ 1.565 & (0.045) & & \\ 1.495 & (0.016) & & \end{array}$

7G) putative extracellular solute-binding protein

$\begin{array}{lll} & 1.736 & (0.017) \\ & 0.637 & (0.025) \\ (<0.001) & 0.557 & (0.024) \\ (0.028) & 0.669 & (0.001)\end{array}$

0.728

$(0.028)$

$(0.035)$ 


\begin{tabular}{|c|c|c|}
\hline YPTBI438 (рерN) & YPOI4I4 & putative aminopeptidase $\mathrm{N}$ \\
\hline YPTBI54I (ysuJ) & YPOI529 & putative decarboxylase \\
\hline YPTBI62I (aroP) & YPOI743 & aromatic amino acid transport protein \\
\hline YPTBI64I (hpaF) & YPOI765 & $\begin{array}{l}\text { 5-carboxymethyl-2-hydroxymuconate delta- } \\
\text { isomerase }\end{array}$ \\
\hline YPTBI656 (ptrB) & YPOI780 & oligopeptidase B \\
\hline YPTBI 889 (lysA) & orl363 & possible diaminopimelate decarboxylase \\
\hline YPTB200I (prsA) & YPO2013 & ribose-phosphate pyrophosphokinase \\
\hline YPTB2019 & YPO2037 & conserved hypothetical protein \\
\hline YPTB2067 & YPO2138 & putative aminotransferase \\
\hline YPTB2 105 (орpA) & YPO2182 & $\begin{array}{l}\text { periplasmic oligopeptide-binding protein } \\
\text { precursoR }\end{array}$ \\
\hline YPTB2 108 (oppD) & YPO2185 & oligopeptide transport ATP-binding protein \\
\hline YPTB2 I 26 (trpB) & YPO2204 & tryptophan synthase beta chain \\
\hline YPTB2258 (mppA) & YPO2339 & $\begin{array}{l}\text { putative periplasmic murein peptide-binding } \\
\text { protein }\end{array}$ \\
\hline YPTB2262 (tyrR) & YPO2344 & transcriptional regulatory protein \\
\hline YPTB2295 (gloA) & YPO238I & lactoylglutathione lyase \\
\hline YPTB2437 (рерT) & YPOI63I & peptidase $T$ \\
\hline YPTB2548 $(g \ln H)$ & YPO25II & putative glutamine-binding periplasmic protein \\
\hline YPTB2549 (glnP) & YPO25I2 & putative glutamine transport system permease \\
\hline YPTB2550 (glnQ) & YPO25I3 & putative glutamine transport ATP-binding protein \\
\hline YPTB2632 (aroC) & YPO275I & chorismate synthase \\
\hline YPTB2698 & YPO2975 & putative aminotransferase \\
\hline YPTB27।4 (cysK) & YPO2992 & cysteine synthase $A$ \\
\hline YPTB2723 & YPO3002 & putative permease \\
\hline YPTB2725 & YPO3004 & putative aminopeptidase (pseudogene. F/S) \\
\hline YPTB2784 (gcvR) & YPO3063 & glycine cleavage system transcriptional repressoR \\
\hline YPTB2869 (glyA) & YPO2907 & serine hydroxymethyltransferase \\
\hline YPTB2882 (yfhB) & YPO2924 & putative membrane protein \\
\hline YPTB2909 & YPO2699 & conserved hypothetical protein \\
\hline YPTB2942 (ureC) & YPO2667 & urease alpha subunit \\
\hline YPTB2943 (ureB) & YPO2666 & urease beta subunit \\
\hline YPTB2944 (ureA) & YPO2665 & urease gamma subunit \\
\hline YPTB296I (proX) & YPO2645 & glycine betaine-binding periplasmic protein \\
\hline YPTB2986 & YPOI06I & conserved hypothetical protein \\
\hline YPTB3006 (dapD) & YPOI04I & $\begin{array}{l}\text { 2.3.4.5-tetrahydropyridine-2-carboxylate } \mathrm{N} \text { - } \\
\text { succinyltransferase }\end{array}$ \\
\hline YPTB3 I8I (gcsH) & YPO0906 & glycine cleavage system $\mathrm{H}$ protein \\
\hline YPTB3 | 82 (gcvT) & YPO0907 & aminomethyltransferase \\
\hline YPTB3 I89 (serA) & YPO09|4 & D-3-phosphoglycerate dehydrogenase \\
\hline YPTB32 I 4 (proC) & YPO0942 & putative pyrroline-5-carboxylate reductase \\
\hline YPTB3474 & YPO0584 & putative symporter protein \\
\hline YPTB3570 (aroQ) & YPO3660 & putative class II dehydroquinase \\
\hline YPTB3658 (metA) & YPO3727 & homoserine O-succinyltransferase \\
\hline YPTB3749 (aroB) & YPO0I52 & 3-dehydroquinate synthase \\
\hline YPTB38I3 (gdhA) & YPO397I & NADP-specific glutamate dehydrogenase \\
\hline
\end{tabular}

$\begin{array}{lc}1.432 & (0.04 I) \\ 2.092 & (<0.00 I) \\ 1.68 & (0.006) \\ 1.812 & (0.015) \\ 1.695 & (0.006) \\ 1.621 & (0.01) \\ 0.55 & (<0.001) \\ 1.56 & (0.02 I)\end{array}$

YPO397I

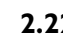

1.376

0.486

1.666

0.488

0.675

2.151

2.108

1.328

1.526

2.302

1.513

0.333

0.2

0.324

0.398

0.377

0.526

I.582

0.61

1.776

0.612

I.67I
0.45

$(<0.001)$

$(<0.00 \mathrm{I})$ $(<0.001)$

$(<0.001)$

$(<0.001)$

(0.039)

$(<0.001)$

$(<0.001)$

$(0.007)$

1.229

(0.042)

1.797

$\begin{array}{ll}1.704 & (0.024) \\ 1.56 & (0.027)\end{array}$

I.56 (0.027)

$(0.031)$

$(<0.001)$

$(0.005)$

$(0.036)$

$(0.022)$

$(<0.001)$

1.685

(0.006)

$1.783(0.001)$
$1.737 \quad(0.006)$

I.737 (0.006)

$(0.017)$

$(<0.001)$

$(<0.001)$

$(<0.001)$

$(<0.001)$

0.637

$0.551 \quad(0.031)$

I.445 (0.005)

$(<0.00 \mathrm{I})$

$(0.022)$

$(0.04)$

0.517

$(0.007)$

$(0.018)$

(0.039)

$(0.005)$

0.72I (0.036) 


\begin{tabular}{|c|c|c|c|c|c|c|}
\hline YPTB3853 (cysM) & or2495 & $\begin{array}{l}\text { Pyridoxal-phosphate dependent protein } \\
\text { (pseudogene. partial) }\end{array}$ & & & 0.415 & $(<0.00 \mathrm{I})$ \\
\hline YPTB3957 & YPO4III & putative periplasmic solute-binding protein & 1.59 & $(0.006)$ & & \\
\hline \multicolumn{7}{|c|}{ F: nucleotide transport and metabolism } \\
\hline YPTB0250 (udp) & YPO3786 & uridine phosphorylase & 0.486 & $(0.005)$ & & \\
\hline YPTB05I9 (nrdD) & YPO3454 & anaerobic ribonucleoside-triphosphate reductase & 0.614 & $(0.024)$ & & \\
\hline YPTB0584 (deoD) & YPO0440 & purine nucleoside phosphorylase & & & 0.607 & $(0.025)$ \\
\hline YPTB0623 (carA) & YPO048I & carbamoyl-phosphate synthase small chain & 0.609 & $(<0.001)$ & 0.747 & $(0.028)$ \\
\hline YPTB0624 (carB) & YPO0482 & carbamoyl-phosphate synthase large chain & 0.621 & $(0.022)$ & 0.546 & $(0.005)$ \\
\hline YPTB0754 (pyrG) & YPO3377 & CTP synthase & 0.469 & $(<0.001)$ & & \\
\hline YPTB090। (gpt) & YPO3225 & xanthine-guanine phosphoribosyltransferase & 0.68 & $(0.035)$ & & \\
\hline YPTB099I (apt) & YPO3123 & adenine phosphoribosyltransferase & 1.447 & $(0.042)$ & & \\
\hline YPTBI253 (nrdB) & YPOI213 & $\begin{array}{l}\text { ribonucleoside-diphosphate reductase I beta } \\
\text { chain }\end{array}$ & & & 0.489 & $(0.003)$ \\
\hline YPTBI254 (nrdA) & YPOI214 & $\begin{array}{l}\text { ribonucleoside-diphosphate reductase I alpha } \\
\text { chain }\end{array}$ & 0.328 & $(<0.00 \mathrm{I})$ & 0.707 & $(0.014)$ \\
\hline YPTBI 439 (pyrD) & YPOI4I5 & dihydroorotate dehydrogenase & & & 1.331 & $(0.037)$ \\
\hline YPTB200। (prsA) & YPO2013 & ribose-phosphate pyrophosphokinase & 0.55 & $(<0.001)$ & & \\
\hline YPTB2 I 02 (tdk) & YPO2I76 & thymidine kinase & 0.75 & $(0.034)$ & & \\
\hline YPTB2706 (nupC) & YPO2983 & nucleoside permease & 1.674 & $(0.018)$ & & \\
\hline YPTB278I (purC) & YPO3059 & $\begin{array}{l}\text { phosphoribosylaminoimidazole- } \\
\text { succinocarboxamide synthase (pseudogene. IS }\end{array}$ & 0.598 & $(0.009)$ & & \\
\hline YPTB2794 (upp) & YPO2827 & uracil phosphoribosyltransferase & 0.515 & $(0.002)$ & & \\
\hline YPTB2796 (purN) & YPO2829 & $\begin{array}{l}\text { putative phosphoribosylglycinamide } \\
\text { formyltransferase }\end{array}$ & & & 1.842 & $(0.038)$ \\
\hline YPTB2803 (ppx) & YPO2837 & putative exopolyphosphatase & & & 0.564 & $(<0.001)$ \\
\hline YPTB2956 (nrdl) & YPO2650 & Nrdl protein homologue & 2.842 & $(<0.001)$ & & \\
\hline YPTB2957 (nrdE) & YPO2649 & $\begin{array}{l}\text { ribonucleoside-diphosphate reductase } 2 \text { alpha } \\
\text { chain }\end{array}$ & 4.745 & $(<0.001)$ & & \\
\hline YPTB2958 (nrdF) & YPO2648 & $\begin{array}{l}\text { ribonucleoside-diphosphate reductase } 2 \text { beta } \\
\text { chain }\end{array}$ & $2.67 \mathrm{I}$ & $(0.002)$ & & \\
\hline YРTB3544 & YPO3689 & putative ribonuclease & & & 1.543 & $(0.022)$ \\
\hline YPTB3854 & YPO40I9 & putative phosphoribosyl transferase protein & & & 0.487 & $(0.001)$ \\
\hline \multicolumn{7}{|c|}{ G: carbohydrate transport and metabolism } \\
\hline YPTB0074 (pfkA) & YPO0078 & 6-phosphofructokinase & 1.593 & $(0.017)$ & & \\
\hline YPTB0087 (glpF) & YPO009I & glycerol uptake facilitator protein & 0.488 & $(0.041)$ & & \\
\hline YPTB024I (ugpC) & YPO3793 & $\begin{array}{l}\text { sn-glycerol-3-phosphate transport. ATP-binding } \\
\text { protein }\end{array}$ & 1.725 & $(0.001)$ & & \\
\hline YРTB0542 & YPO0402 & PTS system. IIB component & & & 0.565 & $(0.023)$ \\
\hline YPTB0548 & YPO0408 & putative aldolase & & & 1.968 & $(0.021)$ \\
\hline YРTB0550 & YPO04I0 & putative $A B C$ transporter permease protein & 0.573 & $(0.033)$ & & \\
\hline YPTB0569 & YPO0424 & putative pectinesterase & 0.268 & $(<0.001)$ & & \\
\hline YPTB0583 (deoB) & YPO0439 & phosphopentomutase & 1.651 & $(0.03)$ & & \\
\hline YPTB0782 (dhaK) & YPO3350 & putative dihydroxyacetone kinase & & & 0.683 & $(0.028)$ \\
\hline YPTB0799 & YPO3332 & $\begin{array}{l}\text { putative sugar } A B C \text { transporter. permease } \\
\text { protein }\end{array}$ & 1.787 & $(0.018)$ & 1.912 & $(0.01)$ \\
\hline YPTB0803 (fucR) & YPO3327 & putative deoR-family regulatory protein & 0.435 & $(<0.001)$ & 1.521 & $(0.007)$ \\
\hline YPTB0804 (araD) & YPO3326 & L-ribulose-5-phosphate 4-epimerase & 0.537 & $(<0.001)$ & & \\
\hline
\end{tabular}




YPTB0874

YPTB 1079

Or0625

probable sugar aldolase

se

conserved hypothetical protein

[28])

YPO2587

YPTBIII9 (nagB)

YPTBII 40

YPO2627

putative glucosamine-6-phosphate isomerase

conserved hypothetical protein

YPTBI $166(\mathrm{gpmA})$

YPOII33

YPTBI 290 (bg/A)

YPTBI 327

YPTBI38I

YPTBI522 (mglB)

YPTBI58I

phosphoglycerate mutase I

6-phospho-beta-glucosidase

YPOI295 putative $A B C$ transport integral membrane

subunit

YPOI355 conserved hypothetical protein

YPOI507 galactose-binding protein

YPOI572 putative sugar transporteR

YPTBI600 (ybtX)

YPTBI632 (manZ)

YPOI915

putative signal transduce $R$

YPOI756

YPTBI 633 (manY)

YPTBI634 (manX)

YPOI757

PTS system. mannose-specific IID component

YPTBI687

YPTB 1930

YPTB 1975

YPTB2047 (pykA)

YPTB2082

YPTB2083 (gapA)

YPTB2 147

YPTB2 $190(\mathrm{mlc})$

YPTB2205

YPTB2306 (pykF)

YPTB23 8 (ppsA)

YPTB2356 (kdul)

YPTB2360

YPTB2463 (ptsG)

YPTB25I5

YPTB2518

YPTB2535 (rbsC)

PTS system. mannose-specific IIC component

PTS system. mannose-specific IIAB component

putative sugar $A B C$ transporter. ATP-binding

protein

YPO1932 putative sugar transporteR

YPOI982 putative dehydrogenase

YPO2064 pyruvate kinase II

YPO2156 conserved hypothetical protein

YPO2157 glyceraldehyde 3-phosphate dehydrogenase A

YPO2225 conserved hypothetical protein

YPO2268 putative ROK family transcriptional regulatory protein

or3894 ABC sugar/ribose transporter. permease subunit

YPO2393

YPO2409

pyruvate kinase

4-deoxy-L-threo-5-hexosulose-uronate ketol-

1.455

1.455
0.559

0.644

$0.042)$

$(0.025)$

$(0.026)$

$\begin{array}{ll}0.654 & (0.027) \\ 0.705 & (0.034)\end{array}$

$0.705 \quad(0.034)$

3.178

$(0.008)$
$(0.009)$

$\begin{array}{ll}1.802 & (0.008) \\ 1.976 & (0.009)\end{array}$

0.683

$(0.031)$

0.56

$(0.002)$

$(0.023)$
$(0.003)$

1.766

$(<0.001)$
$(0.005)$

3.084

1.991

2.674

1.865

$(<0.001)$

$(0.016)$

1.963

0.486

(0.002)

0.538

$(<0.001)$

$(0.002)$

0.63

$(0.012)$

$1.487 \quad(0.03)$

$0.712 \quad(0.027)$

1.417

(0.037)

$(0.041)$

isomerase

YPOI72I putative sugar $A B C$ transporter (permease)

YPOI608 PTS system. glucose-specific IIBC component

YPO2474 conserved hypothetical protein

YPO2477 putative solute-binding protein

YPO2499 putative sugar transport system. permease protein

YPTB27I5 (ptsH)

YPO2993

YPO2994

YPO2995

YPO2644

PTS system. phosphocarrier protein

YPTB2716 (ptsl)
YPTB27I7 (crr)

YPTB2962

YPTB3078

YPTB3 $190($ (rpiA)

YPTB3 $195(f b a A)$

YPTB3 196 (pgk)

YPO0834

YPO0915

YPO0920

YPO0921

PTS sytem. enzyme I component

PTS system. glucose-specific IIA component

conserved hypothetical protein

(pseudogene. ISI00)

putative PTS transport protein

ribose 5-phosphate isomerase $A$

fructose-bisphosphate aldolase class II

phosphoglycerate kinase

YPO0957 putative sugar transport system permease protein

2.282

0.463

1.61

$(0.036)$

$(<0.00 \mathrm{I})$

(0.008)

1.444

$(0.047)$

1.901

4.033

$(0.032)$

$(<0.001)$

$\begin{array}{ll}0.593 & (0.036) \\ 0.62 & (0.029)\end{array}$

1.7

$(0.013)$

1.697

$(0.001)$

$1.945 \quad(<0.001)$

1.611

2.68

$(<0.00 \mathrm{I})$

0.731

(0.028)

0.601

1.325

$(0.021)$

1.742

(0.025)

1.366

$(0.048)$

$(0.024)$

(0.018) 


\begin{tabular}{|c|c|c|c|c|c|c|}
\hline YPTB3230 (mglA) & YPO0958 & putative sugar transport ATP-binding protein & 0.624 & $(0.005)$ & & \\
\hline YPTB3262 & YPO0988 & putative membrane protein & 2.167 & $(<0.001)$ & & \\
\hline YPTB3268 & YPO0995 & Sodium:galactoside symporter family protein & & & 1.764 & $(0.014)$ \\
\hline YPTB3479 (exuT) & YPO0577 & ExuT transport protein & 1.866 & $(0.001)$ & & \\
\hline YPTB3495 & YPO3550 & probable phosphosugar isomerase & & & 0.736 & $(0.042)$ \\
\hline YPTB3536 (treB) & YPO3697 & PTS system. trehalose-specific IIBC component & 0.34 & $(<0.00 \mathrm{I})$ & 1.832 & $(0.015)$ \\
\hline YPTB3537 (treC) & YPO3696 & putative trehalose-6-phosphate hydrolase & 0.279 & $(<0.001)$ & & \\
\hline YPTB3609 & YPO3620 & putative carbohydrate transport protein & & & 1.459 & $(0.02)$ \\
\hline YPTB3642 (lamB) & YPO37II & maltoporin & 0.419 & $(<0.001)$ & & \\
\hline YPTB3779 $(g / p R)$ & YPOOI 20 & glycerol-3-phosphate repressor protein & & & 1.398 & $(0.043)$ \\
\hline YPTB3783 (glgP) & YPO3938 & glycogen phosphorylase & 1.516 & $(0.021)$ & 1.484 & $(0.028)$ \\
\hline YPTB3787 (glgB) & YPO3942 & I.4-alpha-glucan branching enzyme & 0.603 & $(0.001)$ & & \\
\hline \multicolumn{7}{|l|}{$\mathrm{H}$ : coenzyme metabolism } \\
\hline YPTB00I4 (mobA) & or5 120 & $\begin{array}{l}\text { molybdopterin-guanine dinucleotide biosynthesis } \\
\text { protein A }\end{array}$ & & & 0.703 & $(0.032)$ \\
\hline YPTB0056 (kbl) & YPO0059 & 2-amino-3-ketobutyrate coenzyme A ligase & 0.639 & $(0.02)$ & & \\
\hline YPTB0I 34 (ilvG) & YPO390I & acetolactate synthase isozyme II large subunit & & & 0.627 & $(0.039)$ \\
\hline YPTB0 I82 (hemX) & YPO385। & putative uroporphyrin-III C-methyltransferase & & & 0.695 & $(0.033)$ \\
\hline YРTB0264 & YPO3769 & conserved hypothetical protein & & & 0.695 & $(0.01)$ \\
\hline YPTB0290 (thiC) & YPO3739 & thiamine biosynthesis protein ThiC & 2.329 & $(0.012)$ & & \\
\hline YРTB0344 & YPO0286 & putative coproporphyrinogen III oxidase & 1.636 & $(0.015)$ & & \\
\hline YPTB0463 (ispB) & YPO35I3 & octaprenyl-diphosphate synthase & 0.731 & $(0.03)$ & 0.614 & $(0.002)$ \\
\hline YPTB0559 & or0393 & hypothetical protein & 1.723 & $(0.007)$ & & $(<0.001)$ \\
\hline YPTB056I & or0395 & $\begin{array}{l}\text { putative protein involved in molybdopterin } \\
\text { biosynthesis }\end{array}$ & 1.802 & $(0.004)$ & & $(<0.001)$ \\
\hline YPTB0616 (rpsT) & YPO0474 & $30 \mathrm{~S}$ ribosomal protein $\mathrm{S} 20$ & & & 0.59 & $(0.002)$ \\
\hline YPTB0664 & or0477 & hypothetical protein & 0.754 & $(0.035)$ & 1.423 & $(0.01)$ \\
\hline YPTB073I (folK) & YPO3400 & $\begin{array}{l}\text { 2-amino-4-hydroxy-6- } \\
\text { hydroxymethyldihydropteridine } \\
\text { pyrophosphokinase }\end{array}$ & 0.572 & $(0.009)$ & & \\
\hline YPTB0739 (fhuC) & YPO3392 & ferrichrome transport ATP-binding protein FhuC & 1.932 & $(0.046)$ & & \\
\hline YPTB0758 (ygcM) & YPO3373 & $\begin{array}{l}\text { putative 6-pyruvoyl tetrahydrobiopterin synthase } \\
\text { family protein }\end{array}$ & 0.556 & $(0.002)$ & 0.629 & $(0.011)$ \\
\hline YPTB076I (cysH) & YPO3370 & $\begin{array}{l}\text { phosphoadenosine phosphosulfate reductase } \\
\text { (pseudogene. F/S) }\end{array}$ & & & 1.593 & $(0.002)$ \\
\hline YPTB0935 (ribH) & YPO3।82 & 6.7-dimethyl-8-ribityllumazine synthase & & & 0.695 & $(0.01)$ \\
\hline YPTB0940 (ispA) & YPO3।76 & geranyltranstransferase & 0.635 & $(0.026)$ & & \\
\hline YPTBI003 (wbyH) & YPO3III & putative exported protein & & & 0.727 & $(0.039)$ \\
\hline YPTBI09I (lipA) & YPO2598 & lipoic acid synthetase & 0.558 & $(0.002)$ & & \\
\hline YPTBII 63 (pnuC) & YPOII28 & $\begin{array}{l}\text { intergral membrane NMN transport protein } \\
\text { PnuC }\end{array}$ & & & 1.675 & $(0.004)$ \\
\hline YPTBII8I (bioA) & YPOII50 & $\begin{array}{l}\text { adenosylmethionine-8-amino-7-oxononanoate } \\
\text { aminotransferase }\end{array}$ & 3.377 & $(<0.001)$ & 1.592 & $(0.038)$ \\
\hline YPTBII83 (bioF) & YPOII52 & 8-amino-7-oxononanoate synthase & 3.799 & $(<0.001)$ & & \\
\hline YPTB। I 84 (bioC) & YPOII53 & biotin synthesis protein $\mathrm{BioC}$ & 1.784 & $(0.004)$ & 1.636 & $(0.011)$ \\
\hline YPTB। I 85 (bioD) & YPOII54 & dethiobiotin synthetase & 2.499 & $(0.002)$ & & \\
\hline YPTBI343 & YPOI312 & putative siderophore $A B C$ transporter. ATP- & 2.467 & $(<0.001)$ & & \\
\hline
\end{tabular}

YPTBI343

putative siderophore $A B C$ transporter. ATP- 


\begin{tabular}{|c|c|c|c|c|c|c|}
\hline YPTBI384 (poxB) & YPOI358 & pyruvate dehydrogenase [cytochrome] & & & 1.521 & $(0.009)$ \\
\hline YPTBI885 & orl359 & possible ThiF family & & & & $(<0.001)$ \\
\hline YРTB।886 & or 1360 & conserved hypothetical protein & & & & $(<0.001)$ \\
\hline YPTB। 888 & orl362 & conserved hypothetical protein & 1.886 & $(0.001)$ & 0.314 & $(<0.001)$ \\
\hline YPTB2033 & YPO2050 & conserved hypothetical protein & 0.542 & $(0.002)$ & & \\
\hline YPTB2 I 36 (btuR) & YPO2214 & cob(I)alamin adenosyltransferase & 1.975 & $(0.002)$ & & \\
\hline YPTB2191 & YPO2269 & putative dethiobiotin synthetase & 0.3 & $(<0.001)$ & & \\
\hline YPTB2304 (ribE) & YPO239I & riboflavin synthase alpha chain & 1.44 & $(0.012)$ & & \\
\hline YPTB2459 & or3719 & hypothetical & 0.379 & $(<0.001)$ & & \\
\hline YPTB256I (menF) & YPO2528 & menaquinone-specific isochorismate synthase & & & 0.522 & $(0.011)$ \\
\hline YPTB3574 & YPO3657 & putative sodium/panthothenate symporter & & & 0.634 & $(0.01)$ \\
\hline \multicolumn{7}{|l|}{ I: lipid metabolism } \\
\hline YPTB04I6 (psd) & YPO0364 & phosphatidylserine decarboxylase proenzyme & & & 1.846 & $(0.024)$ \\
\hline YPTB0434 (aidB) & YPO0383 & putative acyl-CoA dehydrogenase & 1.613 & $(0.049)$ & & \\
\hline YРTB0558 & or0392 & possible acyl-CoA dehydrogenase & 1.628 & $(0.042)$ & & $(<0.001)$ \\
\hline YРTB0674 & YPO0537 & putative AMP-binding enzyme-family protein & 0.616 & $(0.047)$ & & \\
\hline YPTB0883 (yafH) & YPO3244 & probable acyl-CoA dehydrogenase & 2.292 & $(<0.001)$ & & \\
\hline YPTBI355 & YPOI324 & putative permease & & & 0.499 & $(<0.001)$ \\
\hline YPTB। 450 (fabA) & YPOI430 & $\begin{array}{l}\text { 3-hydroxydecanoyl-[acyl-carrier-protein] } \\
\text { dehydratase }\end{array}$ & & & 0.685 & $(0.033)$ \\
\hline YPTB। 480 & YPOI462 & putative acyl carrier protein & & & 1.669 & $(0.048)$ \\
\hline YPTB2242 (acpD) & YPO2323 & acyl carrier protein phosphodiesterase & & & 0.703 & $(0.013)$ \\
\hline YPTB2470 (acpP) & YPOI600 & acyl carrier protein & & & 0.661 & $(0.002)$ \\
\hline YPTB2473 (fabH) & YPOI597 & 3-oxoacyl-[acyl-carrier-protein] synthase III & 0.757 & $(0.047)$ & 0.708 & $(0.017)$ \\
\hline YPTB2626 (fabB) & YPO2757 & 3-oxoacyl-[acyl-carrier-protein] synthase I & & & 0.605 & $(0.009)$ \\
\hline YPTB2993 (IpxD) & YPOI054 & $\begin{array}{l}\text { UDP-3-o-[3-hydroxymyristoyl] glucosamine } \mathrm{N} \text { - } \\
\text { acyltransferase }\end{array}$ & 1.258 & $(0.018)$ & 0.761 & $(0.007)$ \\
\hline YРTB3849 & YPO40I4 & putative membrane protein & & & 1.549 & $(0.012)$ \\
\hline YРTB3856 & YPO402I & hypothetical protein & & & 0.58 & $(0.012)$ \\
\hline \multicolumn{7}{|c|}{ J: translation, ribosomal structure and biogenesis } \\
\hline YPTB0034 (trmH) & YPO0037 & tRNA (guanosine-2'-O-)-methyltransferase & & & 1.673 & $(0.023)$ \\
\hline YPTB004I (rph) & YPO0044 & ribonuclease $\mathrm{PH}$ & & & 0.667 & $(0.005)$ \\
\hline YPTB0276 (tufA) & or0197 & elongation factor $\mathrm{Tu}$ & & & 0.624 & $(0.001)$ \\
\hline YPTB0279 (rp/K) & YPO375I & $50 \mathrm{~S}$ ribosomal protein LII & 0.703 & $(0.027)$ & 0.682 & $(0.018)$ \\
\hline YPTB0280 (rpIA) & YPO3750 & $50 \mathrm{~S}$ ribosomal protein $\mathrm{LI}$ & 0.681 & $(0.027)$ & 0.689 & $(0.031)$ \\
\hline YPTB028I (rpII) & YPO3749 & $50 S$ ribosomal protein LIO & & & 0.612 & $(0.017)$ \\
\hline YPTB0282 (rp/L) & YPO3748 & 50 S ribosomal protein $\mathrm{L} 7 / \mathrm{L} / 2$ & & & 0.58 & $(0.014)$ \\
\hline YPTB0408 (efp) & YPO0354 & elongation factor $\mathrm{P}$ & 1.7 & $(0.018)$ & & \\
\hline YPTB0438 (rpsF) & YPO3539 & $30 \mathrm{~S}$ ribosomal protein $\mathrm{S} 6$ & 0.597 & $(0.018)$ & 0.501 & $(0.003)$ \\
\hline YPTB044I (rpll) & YPO3536 & 50 S ribosomal protein $\mathrm{L} 9$ & & & 0.476 & $(<0.001)$ \\
\hline YPTB0464 (rplU) & YPO35I2 & 50 S ribosomal protein $\mathrm{L} 2 \mathrm{I}$ & & & 0.539 & $(0.006)$ \\
\hline YPTB0465 (rpmA) & YPO35II & 50 S ribosomal protein $\mathrm{L} 27$ & 0.538 & $(0.002)$ & 0.66 & $(0.026)$ \\
\hline YPTB0480 (infB) & YPO3496 & $\begin{array}{l}\text { translation initiation factor IF2-2 } \\
\text { (pseudogene. inframe deletion) }\end{array}$ & 0.598 & $(<0.001)$ & 0.661 & $(<0.00 \mathrm{I})$ \\
\hline YPTB0483 (rpsO) & YPO3493 & $30 \mathrm{~S}$ ribosomal protein $\mathrm{SI} 5$ & & & 0.647 & $(0.004)$ \\
\hline YPTB0484 (pnp) & YPO3490 & polyribonucleotide nucleotidyltransferase & 0.642 & $(0.006)$ & & \\
\hline YPTB0529 (vals) & YPO3443 & valyl-tRNA synthetase & & & 0.648 & $(0.004)$ \\
\hline
\end{tabular}




\begin{tabular}{|c|c|c|}
\hline YPTB0575 (prfC) & YPO0430 & peptide chain release factor 3 \\
\hline YPTB0732 (pcnB) & YPO3399 & poly $(\mathrm{A})$ polymerase \\
\hline YPTB0794 (map) & YPO3337 & methionine aminopeptidase \\
\hline YPTB0834 (rpsP) & YPO3295 & $30 \mathrm{~S}$ ribosomal protein $\mathrm{SI} 6$ \\
\hline YPTB0835 (rimM) & YPO3294 & I6S rRNA processing protein \\
\hline YPTB0836 (trmD) & YPO3293 & tRNA (guanine-NI)-methyltransferase \\
\hline YPTB0844 (yfiA) & YPO3279 & putative sigma 54 modulation protein \\
\hline YPTB0846 (rluD) & YPO3277 & ribosomal large subunit pseudouridine synthase $d$ \\
\hline YPTBI058 & or0769 & conserved hypothetical protein \\
\hline YPTBII 38 & YPOII04 & conserved hypothetical protein \\
\hline YPTBI366 & YPOI336 & putative RNA methyltransferase \\
\hline YPTBI4II (ansB) & YPOI386 & putative L-asparaginase II precursoR \\
\hline YPTB। 4 I7 (rpsA) & YPOI392 & $30 \mathrm{~S}$ ribosomal protein $\mathrm{SI}$ \\
\hline YPTBI 436 (asnS) & YPOI4I2 & asparaginyl-tRNA synthetase \\
\hline YPTB।953 & YPOI955 & putative acetyltransferase \\
\hline YPTB2005 (prfA) & YPO2017 & peptide chain release factor I \\
\hline YPTB2।35 & YPO2213 & $\begin{array}{l}\text { putative RNA pseudouridylate synthase-family } \\
\text { protein }\end{array}$ \\
\hline YPTB2। 50 & YPO2228 & translation initiation factor SUII family protein \\
\hline YPTB2328 & YPO2420 & probable formyl transferase \\
\hline YPTB2336 (pheT) & YPO2428 & phenylalanyl-tRNA synthetase beta chain \\
\hline YPTB2337 (pheS) & YPO2429 & phenylalanyl-tRNA synthetase alpha chain \\
\hline YPTB2339 (rp/T) & or3807 & 50 S ribosomal protein $\mathrm{L} 20$ \\
\hline YPTB26I8 (truA) & YPO2766 & tRNA pseudouridine synthase $A$ \\
\hline YPTB286I & YPO2898 & putative SpoU-family rRNA methylase \\
\hline YPTB3000 (frr) & YPOI047 & ribosome recycling factoR \\
\hline YPTB3002 (tsf) & YPOI045 & elongation factor Ts \\
\hline YPTB3003 (rpsB) & YPOI044 & $30 \mathrm{~S}$ ribosomal protein $\mathrm{S} 2$ \\
\hline YPTB3009 & YPOI038 & Conserved hypothetical protein \\
\hline YPTB3I 26 & or3195 & Possible bacteriophage protein \\
\hline YPTB3507 (rpsl) & YPO3562 & $30 \mathrm{~S}$ ribosomal protein $\mathrm{S} 9$ \\
\hline YPTB3674 (rpsD) & YPO0233 & $30 \mathrm{~S}$ ribosomal protein $\mathrm{S} 4$ \\
\hline YPTB3675 (rpsK) & YPO0232 & $30 \mathrm{~S}$ ribosomal protein SII \\
\hline YPTB3676 (rpsM) & YPO023I & $30 \mathrm{~S}$ ribosomal protein $\mathrm{SI} 3$ \\
\hline YPTB3679 (rp/O) & YPO0228 & 50 S ribosomal protein LI5 \\
\hline YPTB3682 (rp/R) & YPO0225 & 50 S ribosomal protein LI8 \\
\hline YPTB3684 (rpsH) & or2793 & $30 \mathrm{~S}$ ribosomal protein $\mathrm{S} 8$ \\
\hline YPTB3687 (rpIX) & YPO0221 & 50 S ribosomal protein L24 \\
\hline YPTB3688 (rp/N) & YPO0220 & 50 S ribosomal protein LI4 \\
\hline YPTB3689 (rpsQ) & YPO0219 & $30 \mathrm{~S}$ ribosomal protein $\mathrm{SI} 7$ \\
\hline YРTB369I (rpIP) & YPO0217 & $50 S$ ribosomal protein LI6 \\
\hline YPTB3692 (rpsC) & YPO0216 & 30 S ribosomal protein S3 \\
\hline YPTB3693 (rp/V) & YPO02I5 & 50 S ribosomal protein L22 \\
\hline YPTB3694 (rpsS) & YPO02। 4 & $30 \mathrm{~S}$ ribosomal protein $\mathrm{SI} 9$ \\
\hline YPTB3695 (rp/B) & YPO0213 & 50 S ribosomal protein 12 \\
\hline YPTB3696 (rp/W) & YPO0212 & $50 S$ ribosomal protein $\mathrm{L} 23$ \\
\hline & YPO0210 & $50 S$ ribosomal protein $L 3$ \\
\hline
\end{tabular}

\begin{tabular}{|c|c|c|c|}
\hline 0.536 & $(0.0 \mid 4)$ & $0.61 \mathrm{I}$ & $(0.046)$ \\
\hline 0.74 & $(0.025)$ & & \\
\hline \multirow[t]{2}{*}{3.582} & $(<0.001)$ & & \\
\hline & & 0.682 & $(0.044)$ \\
\hline \multirow[t]{2}{*}{0.628} & $(0.003)$ & 0.68 & $(0.011)$ \\
\hline & & 0.596 & $(0.004)$ \\
\hline \multirow[t]{3}{*}{0.141} & $(<0.00 \mathrm{I})$ & 2.388 & $(0.03)$ \\
\hline & & 0.718 & $(0.04)$ \\
\hline & & 1.626 & $(0.021)$ \\
\hline \multirow[t]{4}{*}{1.634} & $(0.005)$ & & \\
\hline & & 0.588 & $(0.018)$ \\
\hline & & 1.869 & $(0.013)$ \\
\hline & & 0.427 & $(<0.001)$ \\
\hline \multirow[t]{2}{*}{1.628} & $(0.022)$ & & \\
\hline & & 0.594 & $(0.017)$ \\
\hline 0.665 & $(0.008)$ & 0.733 & $(0.035)$ \\
\hline 0.691 & $(0.032)$ & & \\
\hline \multirow[t]{2}{*}{1.574} & $(0.008)$ & & \\
\hline & & 0.578 & $(0.015)$ \\
\hline \multirow[t]{4}{*}{1.646} & $(0.003)$ & & \\
\hline & & 0.615 & $(0.016)$ \\
\hline & & 0.719 & $(0.017)$ \\
\hline & & 0.52 & $(0.01)$ \\
\hline \multirow[t]{5}{*}{0.586} & $(<0.001)$ & & \\
\hline & & 0.609 & $(0.026)$ \\
\hline & & 0.611 & $(0.047)$ \\
\hline & & 0.464 & $(<0.001)$ \\
\hline & & 0.761 & $(0.039)$ \\
\hline 1.616 & $(0.029)$ & & \\
\hline \multirow[t]{6}{*}{0.723} & $(0.037)$ & 0.582 & $(0.001)$ \\
\hline & & 0.576 & $(0.002)$ \\
\hline & & 0.594 & $(0.017)$ \\
\hline & & 0.518 & $(0.005)$ \\
\hline & & 0.593 & $(0.008)$ \\
\hline & & 0.563 & $(0.005)$ \\
\hline \multirow[t]{8}{*}{0.638} & $(0.042)$ & 0.619 & $(0.032)$ \\
\hline & & 0.574 & $(0.005)$ \\
\hline & & 0.634 & $(0.015)$ \\
\hline & & 0.58 & $(0.016)$ \\
\hline & & 0.511 & $(<0.001)$ \\
\hline & & 0.642 & $(0.028)$ \\
\hline & & 0.466 & $(0.003)$ \\
\hline & & 0.612 & $(0.013)$ \\
\hline \multirow[t]{3}{*}{0.555} & $(<0.00 \mathrm{I})$ & 0.596 & $(<0.001)$ \\
\hline & & 0.509 & $(0.001)$ \\
\hline & & 0.465 & $(0.001)$ \\
\hline
\end{tabular}

50 S ribosomal protein 13 


\begin{tabular}{|c|c|c|c|c|c|c|}
\hline YPTB3699 (rpsl) & YPO0209 & 30S ribosomal protein $\mathrm{SIO}$ & 0.654 & $(0.049)$ & 0.579 & $(0.014)$ \\
\hline YPTB3702 (tufA,tufB) & or2775 & elongation factor EF-Tu & & & 0.672 & $(0.003)$ \\
\hline YPTB3703 (fusA) & YPO0202 & elongation factor $\mathrm{G}$ & & & 0.536 & $(0.002)$ \\
\hline YPTB3946 (rnpA) & YPO4IOI & ribonuclease $\mathrm{P}$ protein & 0.58 & $(0.005)$ & & \\
\hline \multicolumn{7}{|l|}{ K: transcription } \\
\hline YPTB0035 (spot) & YPO0038 & $\begin{array}{l}\text { guanosine-3'.5'-bisbis(diphosphate) 3'- } \\
\text { Pyrophosphydrolase }\end{array}$ & 0.684 & $(0.011)$ & & \\
\hline YPTB0100 (cytR) & YPO0108 & transcriptional repressoR & 0.572 & $(0.014)$ & & \\
\hline YPTB0167 (rho) & YPO3867 & transcription termination facto $R$ & 0.467 & $(<0.001)$ & & \\
\hline YPTB0263 (rfaH) & YPO3770 & putative regulatory protein & & & 0.552 & $(0.001)$ \\
\hline YPTB0278 (nusG) & YPO3752 & transcription antitermination protein & & & 0.57 & $(0.001)$ \\
\hline YPTB0284 (rpoC) & YPO3746 & DNA-directed RNA polymerase beta' chain & & & 0.556 & $(0.019)$ \\
\hline YPTB029I (rsd) & YPO3737 & regulator of sigma $D$ & 1.963 & $(<0.001)$ & 0.632 & $(0.002)$ \\
\hline YРTB0333 & YPO0276 & putative LysR-family transcriptional regulatoR & & & 0.62 & $(0.044)$ \\
\hline YPTB0387 (rhaR) & YPO0333 & L-rhamnose operon transcriptional activatoR & 0.546 & $(0.025)$ & & \\
\hline YPTB0479 (nusA) & YPO3497 & $N$ utilization substance protein $A$ & 0.653 & $(0.006)$ & 0.595 & $(0.001)$ \\
\hline YPTB0599 (rob) & YPO0456 & putative right origin-binding protein & & & 0.588 & $(0.012)$ \\
\hline YPTB060I (arcA) & YPO0458 & aerobic respiration control protein & 0.465 & $(0.001)$ & & \\
\hline YPTB0658 (rapA) & YPO05I7 & RNA polymerase associated helicase & 0.547 & $(0.004)$ & & \\
\hline YPTB07I2 (pdhR) & YPO3420 & pyruvate dehydrogenase complex repressoR & 0.808 & $(0.004)$ & 0.695 & $(<0.001)$ \\
\hline YPTB0776 (rpos) & YPO3355 & RNA polymerase sigma factor RpoS & & & 0.559 & $(0.001)$ \\
\hline YPTB0803 (fucR) & YPO3327 & putative deoR-family regulatory protein & 0.435 & $(<0.001)$ & 1.521 & $(0.007)$ \\
\hline YPTB0820 & YPO3310 & putative transcriptional regulatory protein & 0.712 & $(0.022)$ & & \\
\hline YPTB0857 (emrR) & YPO3266 & MarR-family transcriptional regulatory protein & 0.662 & $(0.029)$ & & \\
\hline YPTBI 088 (cspE) & YPO2595 & putative cold shock protein & 0.579 & $(0.005)$ & & \\
\hline YPTB 258 (rcsB) & YPOI218 & $\begin{array}{l}\text { probable two component response regulator } \\
\text { component B }\end{array}$ & & & 0.693 & $(0.016)$ \\
\hline YPTB।332 (psaE) & YPOI30I & putative regulatory protein & 1.986 & $(0.001)$ & 0.474 & $(<0.001)$ \\
\hline YPTB। 392 (cspD) & YPOI366 & cold shock-like protein & 0.46 & $(0.008)$ & & \\
\hline YPTB। 423 (cspE) & YPOI398 & putative cold shock protein & 0.579 & $(0.005)$ & & \\
\hline YPTB 610 (thuR) & orll 88 & $\begin{array}{l}\text { putative ThuR. regulatory protein for } \\
\text { trehalosemaltose transp... }\end{array}$ & & & 1.403 & $(0.025)$ \\
\hline YPTB।72I & YPOI849 & conserved hypothetical (pseudogene. F/S) & 1.366 & $(0.025)$ & & \\
\hline YPTBI 967 (hutC) & YPOI973 & $\begin{array}{l}\text { putative GntR-family transcriptional regulatory } \\
\text { protein }\end{array}$ & 0.739 & $(0.018)$ & & \\
\hline YPTB2048 (hexR) & YPO2065 & hex regulon represso $R$ & & & $1.5 \mathrm{I}$ & $(0.013)$ \\
\hline YPTB2072 (fadR) & YPO2। 44 & fatty acid metabolism regulatory protein & & & 1.494 & $(0.01)$ \\
\hline YPTB2 I77 (araC) & YPO2258 & arabinose operon regulatory protein & & & 1.591 & $(0.002)$ \\
\hline YPTB2 $190(\mathrm{~m} / \mathrm{c})$ & YPO2268 & $\begin{array}{l}\text { putative ROK family transcriptional regulatory } \\
\text { protein }\end{array}$ & 1.417 & $(0.037)$ & & \\
\hline YPTB2230 (rstA) & YPO2308 & $\begin{array}{l}\text { two-component regulatory system. response } \\
\text { regulator protein }\end{array}$ & 0.658 & $(0.024)$ & & \\
\hline YPTB2262 (tyrR) & YPO2344 & transcriptional regulatory protein & 0.486 & $(<0.001)$ & & \\
\hline YPTB2288 (rovA) & YPO2374 & MarR-family transcriptional regulatory protein & & & 0.415 & $(<0.001)$ \\
\hline YPTB2367 (kdgR) & YPOI7I4 & IcIR-family transcriptional regulatory protein & & & 0.75 & $(0.029)$ \\
\hline YPTB24I4 (cspC) & or3750 & cold shock protein & & & 0.685 & $(0.014)$ \\
\hline YPTB2418 & YPOI65I & AsnC-family transcriptional regulatory protein & 0.435 & $(<0.001)$ & & \\
\hline
\end{tabular}

YPTB2072 (fadR)

YPTB2190 (mlc)

0.58

$(0.005)$

$0.57 \quad(0.001)$

$0.632-(0.002)$

YPO3737

1.963

$(0.044)$

L-rhamnose operon transcriptional activatoR

Nutilization substance protein $A$

putative right origin-binding protein

aerobic respiration control protein

putative deoR-family regulatory protein

MarR-family transcriptional regulatory prote

putative cold shock protein

0.693

$(0.016)$

component B

trehalosemaltose transp...

conserved hypothetical (pseudogene. F/S)

putative GntR-family transcriptional regulatory

AsnC-family transcriptional regulatory protein 


\begin{tabular}{|c|c|c|}
\hline YPTB2534 & YPO2498 & $\begin{array}{l}\text { putative Lacl-family transcriptional regulatory } \\
\text { protein }\end{array}$ \\
\hline YPTB2737 & YPO3017 & $\begin{array}{l}\text { putative rpiR-family transcriptional regulatory } \\
\text { protein }\end{array}$ \\
\hline YPTB2763 (narP) & YPO304I & nitrate/nitrite response regulator protein $\mathrm{Nar} P$ \\
\hline YPTB2860 & YPO2897 & conserved hypothetical protein \\
\hline YPTB2865 & YPO2903 & putative RNA-binding protein \\
\hline YPTB2890 (rnc) & YPO27I8 & ribonuclease III \\
\hline YPTB2897 (rpoE) & YPO27II & RNA polymerase sigma $E$ factoR \\
\hline YPTB2939 (ureG) & YPO2670 & urease accessory protein \\
\hline YPTB30I7 (gcvA) & YPOI029 & glycine cleavage system transcriptional activatoR \\
\hline YPTB3490 & YPO3545 & lysR-family transcriptional regulatory protein \\
\hline YPTB35I4 & YPO3570 & BolA-like protein \\
\hline YPTB3538 (rnk) & YPO3695 & regulator of nucleoside diphosphate kinase \\
\hline YPTB3577 (fiS) & or2359 & DNA-binding protein Fis \\
\hline YPTB3579 & YPO365I & $\begin{array}{l}\text { Transcriptional regulator } \\
\text { (pseudogene. inframe deletion) }\end{array}$ \\
\hline YPTB3764 (greB) & YPO0I36 & transcription elongation factor \\
\hline YPTB3779 (glpR) & YPOOI 20 & glycerol-3-phosphate repressor protein \\
\hline YPTB3798 (gntR) & YPO3955 & $\begin{array}{l}\text { gluconate utilization system Gnt-l transcriptional } \\
\text { repressoR }\end{array}$ \\
\hline YPTB3847 (uhpA) & YPO40I2 & two-component system response regulatoR \\
\hline YPTB3887 & YPO4034 & $\begin{array}{l}\text { putative AraC-family transcriptional regulatory } \\
\text { protein }\end{array}$ \\
\hline \multicolumn{3}{|c|}{ lication, recombination and repair } \\
\hline YPTB0046 (radC) & YPO0049 & putative DNA repair protein \\
\hline YPTB026I & or0185 & $\begin{array}{l}\text { cytoplasmic Dnase } \\
\text { (function similar to TatD) }\end{array}$ \\
\hline YPTB0292 & YPO3736 & conserved hypothetical protein \\
\hline YPTB0297 (hupA) & YPO373I & DNA-binding protein HU-alpha \\
\hline YPTB0302 (or02 I 8) & or0218 & putative transposase \\
\hline YPTB0439 (priB) & YPO3538 & primosomal replication protein $\mathrm{n}$ \\
\hline YPTB0498 & YPO3475 & conserved hypothetical protein \\
\hline YPTB0579 & YPO0434 & putative metalloenzyme \\
\hline YPTB0658 (rapA) & YPO05I7 & RNA polymerase associated helicase \\
\hline YPTB09|3 (rdgC) & YPO3212 & possible recombination associated protein $\mathrm{RdgC}$ \\
\hline YPTB094I (xseB) & YPO3।75 & exodeoxyribonuclease VII small subunit \\
\hline YPTB0962 (hupB) & YPO3I54 & DNA-binding protein HU-beta \\
\hline YPTB0964 (ybaV) & YPO3I52 & putative exported protein \\
\hline YPTBI4I8 (ihfB) & YPOI393 & integration host factor beta-subunit \\
\hline YPTB।799 & orl306 & putative modification methylase \\
\hline YPTB2040 (ruvA) & YPO2057 & Holliday junction DNA helicase \\
\hline YPTB2 I 40 (topA) & YPO2218 & DNA topoisomerase I \\
\hline YPTB222। (ogt) & YPO2299 & $\begin{array}{l}\text { putative methylated-DNA - protein-cysteine } \\
\text { methyltransferase }\end{array}$ \\
\hline YPTB2335 (ihfA) & YPO2427 & integration host factor alpha-subunit \\
\hline YPTB2458 & or3720 & hypothetical \\
\hline
\end{tabular}

\begin{tabular}{|c|c|c|c|}
\hline \multirow[t]{2}{*}{1.601} & \multirow[t]{2}{*}{$(0.036)$} & & \\
\hline & & 0.715 & $(0.043)$ \\
\hline \multirow[t]{4}{*}{1.578} & \multirow[t]{4}{*}{$(0.011)$} & 0.632 & $(0.01)$ \\
\hline & & 0.652 & $(0.035)$ \\
\hline & & 0.673 & $(0.013)$ \\
\hline & & 1.827 & $(<0.001)$ \\
\hline 0.293 & $(<0.001)$ & & \\
\hline 1.634 & $(0.049)$ & & \\
\hline 1.503 & $(0.036)$ & 1.518 & $(0.032)$ \\
\hline 1.315 & $(0.035)$ & & \\
\hline 0.564 & $(0.016)$ & & \\
\hline \multirow[t]{7}{*}{0.611} & $(0.034)$ & 0.58 & $(0.02)$ \\
\hline & & 0.675 & $(0.017)$ \\
\hline & & 0.69 & $(0.004)$ \\
\hline & & 1.398 & $(0.043)$ \\
\hline & & 1.589 & $(0.042)$ \\
\hline & & 2.004 & $(0.006)$ \\
\hline & & 1.495 & $(0.04)$ \\
\hline \multirow{4}{*}{$\begin{array}{l}1.544 \\
0.569\end{array}$} & $(0.026)$ & 0.575 & $(0.006)$ \\
\hline & $(<0.001)$ & & \\
\hline & & 1.453 & $(0.017)$ \\
\hline & & 0.455 & $(<0.001)$ \\
\hline \multirow[t]{2}{*}{1.478} & $(0.046)$ & 1.834 & $(0.004)$ \\
\hline & & 0.557 & $(0.045)$ \\
\hline 0.554 & $(0.013)$ & & \\
\hline 0.64 & $(0.023)$ & & \\
\hline 0.547 & $(0.004)$ & & \\
\hline 1.82 & $(0.047)$ & & \\
\hline 0.647 & $(0.044)$ & & \\
\hline 1.674 & $(<0.001)$ & 0.727 & $(0.015)$ \\
\hline \multirow{2}{*}{0.625} & $(0.02)$ & & \\
\hline & & 0.46 & $(0.003)$ \\
\hline 1.94 & $(0.026)$ & & \\
\hline 1.225 & $(0.04)$ & & \\
\hline 1.654 & $(0.012)$ & 0.548 & $(0.004)$ \\
\hline 0.611 & $(0.017)$ & & \\
\hline 1.626 & $(0.001)$ & 0.623 & $(0.001)$ \\
\hline 0.501 & $(<0.001)$ & & \\
\hline
\end{tabular}




\begin{tabular}{|c|c|c|c|c|c|c|}
\hline YPTB2792 & YPO307I & conserved hypothetical protein & & & 1.337 & $(0.026)$ \\
\hline YPTB2834 (xseA) & YPO2872 & exodeoxyribonuclease VII large subunit & & & 0.639 & $(0.01)$ \\
\hline YPTB3389 & YPO0674 & putative MutT-family protein & 1.299 & $(0.044)$ & & \\
\hline YPTB3577 (fiS) & or2359 & DNA-binding protein Fis & $0.6 \mathrm{II}$ & $(0.034)$ & 0.58 & $(0.02)$ \\
\hline YPTB3757 & YPO0I44 & putative hydrolase & 1.58 & $(0.013)$ & & \\
\hline \multicolumn{7}{|c|}{ M: cell envelope biogenesis, outer membrane } \\
\hline YPTB005I (kdtX) & YPO0054 & $\begin{array}{l}\text { lipopolysaccharide core biosynthesis glycosyl } \\
\text { transferase }\end{array}$ & 0.592 & $(0.001)$ & & \\
\hline YPTB0I73 (rffH) & YPO386I & glucose-I-phosphate thymidylyltransferase & & & 1.604 & $(0.028)$ \\
\hline YPTB04I5 & YPO0363 & putative membrane transport protein & & & 1.853 & $(0.003)$ \\
\hline YРTB049I & YPO3483 & multidrug efflux protein & & & 1.833 & $(0.032)$ \\
\hline YPTB0493 (ibeB) & YPO348I & probable outer membrane efflux lipoprotein & 1.863 & $(0.015)$ & & \\
\hline YPTB0694 (lpxC) & YPO056I & $\begin{array}{l}\text { UDP-3-O-[3-hydroxymyristoyl] N- } \\
\text { acetylglucosamine deacetylase }\end{array}$ & 0.787 & $(0.04)$ & & \\
\hline YPTB0775 (nlpD) & YPO3356 & lipoprotein & 1.345 & $(0.019)$ & 0.732 & $(0.015)$ \\
\hline YPTB0906 & YPO3220 & conserved hypothetical protein & & & 0.651 & $(0.038)$ \\
\hline YPTB0955 (yajG) & YPO316I & putative lipoprotein & 1.48 & $(0.021)$ & & \\
\hline YPTB0987 (kefA) & YPO3I29 & putative potassium efflux system & 0.626 & $(0.001)$ & & \\
\hline YPTBI002 (prt) & YPO3।I2 & paratose synthase & & & 0.706 & $(0.013)$ \\
\hline YPTBI 008 (wbyK) & YPO3104 & putative mannosyltransferase & 0.527 & $(0.001)$ & 0.669 & $(0.03)$ \\
\hline YPTBI0I4 (wzz) & YPO3096 & O-antigen chain length determinant & & & 0.577 & $(0.019)$ \\
\hline YPTB। 109 (cutE) & YPO2616 & putative apolipoprotein $\mathrm{N}$-acyltransferase & 0.669 & $(0.029)$ & & \\
\hline YPTBII 60 (pal) & YPOII25 & peptidoglycan-associated lipoprotein $\mathrm{Pal}$ & 1.649 & $(<0.00 \mathrm{I})$ & 0.553 & $(<0.001)$ \\
\hline YPTB 1217 (pbpG) & YPOII76 & penicillin-binding protein 7 precursoR & 0.565 & $(0.009)$ & & \\
\hline YPTBI26I (ompC) & YPOI 222 & outer membrane protein $C$. porin & 0.284 & $(<0.001)$ & 1.371 & $(0.034)$ \\
\hline YPTBI 266 (pla2) & YPOI23I & putative outer membrane-associated protease & 0.569 & $(0.015)$ & & \\
\hline YPTB। 309 (spr) & YPOI 275 & putative lipoprotein & 0.499 & $(<0.001)$ & 0.646 & $(0.002)$ \\
\hline YPTBI38I & YPOI355 & conserved hypothetical protein & 0.683 & $(0.031)$ & & \\
\hline YPTB।435 & YPOI4II & putative outer membrane porin $C$ protein & & & & $(<0.001)$ \\
\hline YPTBI453 (ompA) & YPOI435 & putative outer membrane porin $A$ protein & & & 0.355 & $(<0.001)$ \\
\hline YPTB 1514 & YPOI498 & putative exported protein & & & 0.301 & $(<0.001)$ \\
\hline YPTBI 528 (yohK) & YPOI5I3 & putative membrane protein & 1.513 & $(0.043)$ & & \\
\hline YPTBI73I & YPOI860 & attachment invasion locus protein & & & 1.634 & $(<0.001)$ \\
\hline YPTB।819 & orl328 & hypothetical phage protein & 1.902 & $(0.025)$ & & \\
\hline YPTB 1964 & or 1419 & putative outer membrane porin $C$ protein & & & & $(<0.001)$ \\
\hline YPTB 1975 & YPOI982 & putative dehydrogenase & & & 0.63 & $(0.012)$ \\
\hline YPTB208I & YPO2I55 & putative exported protein & 0.796 & $(0.009)$ & & \\
\hline YPTB21।3 & YPO2190 & attachment invasion locus protein precursoR & I.5 I I & $(0.012)$ & & $(<0.001)$ \\
\hline YPTB2। I 7 (tonB) & YPO2193 & TonB & 5.465 & $(<0.001)$ & & \\
\hline YPTB2 I 23 (ompW) & YPO220I & putative exported protein & 0.165 & $(<0.001)$ & & \\
\hline YPTB2233 (sepC) & YPO23I2 & $\begin{array}{l}\text { insecticidal toxin } \\
\text { (pseudogene. inframe insertion) }\end{array}$ & 1.424 & $(0.045)$ & & \\
\hline YPTB2294 (sepC) & YPO2380 & $\begin{array}{l}\text { insecticidal toxin } \\
\text { (pseudogene. inframe insertion) }\end{array}$ & 1.424 & $(0.045)$ & & \\
\hline YPTB2323 (nlpC) & YPO24I5 & putative lipoprotein & 1.388 & $(0.025)$ & & \\
\hline YPTB2979 (cutF) & YPOI067 & putative copper homeostasis lipoprotein & 1.794 & $(0.001)$ & & \\
\hline
\end{tabular}


Table 2: Y. pseudotuberculosis IP32953 chromosomal genes (sorted by COG class [28]) that are transcriptionally regulated by growth medium and/or temperature. (Continued)

\begin{tabular}{|c|c|c|c|}
\hline & YPTB2994 (ompH) & YPOI053 & $\begin{array}{l}\text { cationic } 19 \mathrm{kDa} \text { outer membrane protein } \\
\text { precursoR }\end{array}$ \\
\hline & YPTB2995 & YPOI052 & putative surface antigen \\
\hline & YPTB2996 & YPOI05I & putative membrane protein \\
\hline & YРTB3।94 & YPO0919 & putative membrane protein \\
\hline & YPTB3277 & or309l & Conserved hypothetical protein \\
\hline & YPTB3282 & or3086 & Conserved hypothetical protein (partial. c-term) \\
\hline & YPTB3285 & or3082 & Putative autotransporter secreted protein \\
\hline & YPTB33। 3 (slyB) & YPO0752 & putative lipoprotein \\
\hline & YPTB3407 (rfaE) & YPO0654 & ADP-heptose synthase \\
\hline & YРTB3438 & YPO0617 & putative membrane protein \\
\hline & YPTB3497 (mtgA) & YPO3552 & $\begin{array}{l}\text { monofunctional biosynthetic peptidoglycan } \\
\text { transglycosylase }\end{array}$ \\
\hline & YPTB35I3 (murA) & YPO3569 & $\begin{array}{l}\text { UDP-N-acetylglucosamine I- } \\
\text { carboxyvinyltransferase }\end{array}$ \\
\hline & YPTB37I7 & YPO0I87 & putative glycosyl transferase \\
\hline & YPTB3958 & YPO4II2 & putative membrane protein \\
\hline & YPTB3965 (glmU) & YPO4II9 & UDP-N-acetylglucosamine pyrophosphorylase \\
\hline \multicolumn{4}{|c|}{$N$ : cell motility and secretion } \\
\hline & YPTB007I (cpxP) & YPO0075 & putative exported protein \\
\hline & YPTBOI56 & YPO388I & putative chaperone protein \\
\hline & YPTB0I58 & YPO3879 & putative outer membrane usher protein \\
\hline & YРTB0359 & YPO0302 & putative outer membrane fimbrial usher protein \\
\hline & YPTB0706 (hofB) & YPO3426 & putative type II secretion system protein \\
\hline & YPTB। 335 (psaB) & YPOI304 & chaperone protein $\mathrm{PsaB}$ precursoR \\
\hline & YPTBI680 (flg) & YPOI807 & flagellar protein Flg \\
\hline & YPTBI68I (flgK) & YPOI808 & flagellar hook-associated protein I \\
\hline & YPTBI 682 (flgL) & YPOI809 & flagellar hook-associated protein 3 \\
\hline & YPTBI693 & YPOI820A & \\
\hline & YPTBI695 (fliN) & YPOI822 & flagellar motor switch protein FliN \\
\hline & YPTB I 698 (fliK) & YPOI825 & flagellar hook-length control protein FliK \\
\hline & YPTB।919 & YPOI920 & probable fimbrial usher protein \\
\hline & YPTB2396 (cheZ) & YPOI68I & chemotaxis protein CheZ \\
\hline & YPTB2405 (cheA) & YPOI666 & chemotaxis protein CheA \\
\hline & YPTB2843 & YPO288I & putative fimbrial biogenesis protein \\
\hline & YPTB3347 (fliG) & YPO07I5 & puative flagellar motor switch protein \\
\hline & YРTB3357 & YPO0704 & flagellar assembly protein \\
\hline & YPTB3896 & YPTB3896 & fimbrial protein \\
\hline \multicolumn{4}{|l|}{ No COG } \\
\hline & YPTB0092 & YPO0I00 & hypothetical protein \\
\hline & YРTB0094 & YPO0I02 & putative exported protein \\
\hline & YPTB0I23 (yijD) & YPO39I2 & putative membrane protein \\
\hline & YPTB0I39 & YPO3895 & putative membrane protein \\
\hline & YPTB0I4I & YPTB0I4I & putative membrane protein \\
\hline & YPTBOI 48 & or0096 & $\begin{array}{l}\text { colicin } \\
\text { (pseudogene. partial) }\end{array}$ \\
\hline & YРTB0I49 & or0097 & putative colicin immunity protein \\
\hline
\end{tabular}

$\begin{array}{llll}1.69 & (<0.00 I) & 0.538 & (<0.00 \mathrm{I}) \\ 1.53 \mathrm{I} & & 0.745 & (0.016) \\ 1.569 & (0.03) & & \\ 1.529 & (0.024) & 1.57 & (0.026) \\ & (0.025) & & \\ 1.452 & & 1.593 & (0.028) \\ 0.709 & (0.003) & & \\ 1.993 & (0.042) & & \\ & (0.004) & 1.736 & (0.008) \\ & & 0.775 & (0.034)\end{array}$

$\begin{array}{lccc}0.657 & (0.013) & & \\ 1.69 & (0.004) & & \\ 1.572 & (0.042) & & \\ & & 0.337 & (<0.001) \\ 0.657 & (0.01) & 1.626 & (0.016) \\ & & & \\ 1.398 & (0.049) & & \\ 0.711 & (0.043) & & \\ 0.216 & (<0.001) & 1.906 & (0.01) \\ & & 0.682 & (0.034) \\ 0.616 & (0.01) & & \\ 1.514 & (0.041) & 2.053 & (0.011) \\ & & 1.79 & (0.021) \\ & & 1.941 & (0.006) \\ & & 1.461 & (0.019) \\ 1.725 & & 1.477 & (0.027) \\ 1.68 & (0.015) & & \\ 0.611 & & 0.686 & (0.022) \\ & (0.03) & 1.722 & (0.024) \\ 1.623 & (0.049) & & \\ & & 1.644 & (0.021) \\ & & & \\ 1.774 & (0.025) & 0.434 & (<0.001) \\ & & 0.503 & (<0.001) \\ & & 0.669 & (0.033) \\ & (0.026) & 0.717 & (0.036) \\ & & & \end{array}$

$\begin{array}{ll}1.774 & (0.026) \\ 1.493 & (0.013)\end{array}$




\begin{tabular}{|c|c|c|}
\hline YPTB0I5I (imm2) & or0099 & pyocin S2 immunity protein \\
\hline YPTB02 I 2 (dcrB) & YPO3823 & putative lipoprotein \\
\hline YPTB0237 & or5000 & putative exported protein \\
\hline YPTB0244 & or0169 & hypothetical \\
\hline YPTB0362 & YPO0306 & $\begin{array}{l}\text { conserved hypothetical protein } \\
\text { (pseudogene. F/S) }\end{array}$ \\
\hline YРTB039I & YPO0337 & putative exported protein \\
\hline YPTB0406 & YPO0352 & putative lipoprotein \\
\hline YPTB0449 & YPO3527 & conserved hypothetical protein \\
\hline YPTB0499 & YPO3474 & hypothetical protein \\
\hline YPTB0505 & YPO3468 & hypothetical protein \\
\hline YPTB0546 & YPO0406 & putative exported protein \\
\hline YPTB0560 & or0394 & hypothetical protein \\
\hline YPTB0593 & YPO0450 & putative membrane protein \\
\hline YPTB065I & YPO05II & hypothetical protein \\
\hline YPTB0657 & YPO0516 & hypothetical protein \\
\hline YPTB0666 & or4788 & putative ISI 400 transposase B \\
\hline YPTB0678 & YPO0544 & putative membrane protein \\
\hline YРTB0768 (ygbE) & YPO3363 & putative membrane protein \\
\hline YРTB0793 & YPO3339 & hypothetical protein \\
\hline YPTB0795 & YPO3336 & conserved hypothetical protein \\
\hline YPTB0903 (crl) & YPO3223 & curlin genes regulatory protein \\
\hline YPTB0957 & YPO3I59 & hypothetical protein \\
\hline YPTB0978 (ymoA) & YPO3।38 & $\begin{array}{l}\text { modulating protein YmoA } \\
\text { (histone-like protein) }\end{array}$ \\
\hline YPTB0979 & YPO3।37 & conserved hypothetical protein \\
\hline YPTB0980 & YPO3I36 & hypothetical protein \\
\hline YPTBI004 (wzx) & or0734 & putative O-unit flippase \\
\hline YPTBI0I8 (ushB) & or0747 & 5'-nucleotidase/UDP-sugar diphosphatase \\
\hline YPTBI04I & YPO2820 & hypothetical protein \\
\hline YPTBI042 (int) & or4598 & phage integrase (pseudogene. Partial) \\
\hline YPTB 1043 & or0754 & hypothetical \\
\hline YPTB I I 30 (trp / 400A) & or453I & ISI 400 transposase A \\
\hline YPTB।I67 (psiF) & YPOII34 & putative starvation-inducible protein \\
\hline YPTB। 202 (харB) & YPOII72 & xanthosine permease (pseudogene. ISI54I) \\
\hline YPTB I 220 & YPOII79 & conserved hypothetical protein \\
\hline YPTB। 287 & or0929 & putative bacteriophage tail fiber protein \\
\hline YPTBI29I & YPOI 255 & hypothetical protein \\
\hline YPTBI303 & YPOI269 & conserved hypothetical protein \\
\hline YPTBI334 (psaA) & YPOI303 & pH 6 antigen precursor (antigen 4) (adhesin) \\
\hline YPTBI359 & YPOI328 & putative membrane protein \\
\hline YPTBI5I5 & YPOI499 & putative membrane protein \\
\hline YPTBI543 (ysuH) & YPOI53I & putative siderophore biosynthetic enzyme \\
\hline YPTBI583 & YPOI574 & putative exported protein \\
\hline YPTBI 602 (int) & or4274 & integrase \\
\hline YPTB 1616 & orl193 & conserved hypothetical protein \\
\hline YPTB 1619 & YPOI74I & hypothetical protein \\
\hline
\end{tabular}

\begin{tabular}{|c|c|c|c|}
\hline 1.549 & $(0.013)$ & 0.486 & $(<0.001)$ \\
\hline \multirow[t]{2}{*}{0.758} & $(0.028)$ & & \\
\hline & & 1.357 & $(0.048)$ \\
\hline \multirow[t]{3}{*}{0.517} & $(<0.00 \mathrm{I})$ & & \\
\hline & & 0.66 & $(0.036)$ \\
\hline & & 0.527 & $(<0.001)$ \\
\hline \multirow[t]{4}{*}{1.294} & $(0.042)$ & & \\
\hline & & 2 & $(<0.001)$ \\
\hline & & 1.509 & $(0.036)$ \\
\hline & & 1.632 & $(0.026)$ \\
\hline 2.397 & $(<0.00 \mathrm{I})$ & & \\
\hline 1.636 & $(0.028)$ & 0.27 I & $(<0.001)$ \\
\hline \multirow[t]{3}{*}{0.736} & $(0.025)$ & 1.464 & $(0.007)$ \\
\hline & & 0.576 & $(0.02)$ \\
\hline & & 0.457 & $(0.001)$ \\
\hline \multirow[t]{2}{*}{2.101} & $(<0.00 \mathrm{I})$ & & \\
\hline & & 0.631 & $(0.009)$ \\
\hline 1.735 & $(0.007)$ & & \\
\hline 1.679 & $(0.023)$ & 1.94 & $(0.005)$ \\
\hline 3 & $(<0.001)$ & & \\
\hline \multirow[t]{2}{*}{2.098} & $(<0.001)$ & & \\
\hline & & I.52I & $(0.034)$ \\
\hline 0.509 & $(<0.001)$ & & \\
\hline 0.469 & $(<0.001)$ & & \\
\hline \multirow[t]{3}{*}{0.587} & $(0.01)$ & & \\
\hline & & 0.642 & $(0.007)$ \\
\hline & & 1.34 & $(0.031)$ \\
\hline \multirow[t]{2}{*}{1.394} & $(0.029)$ & & \\
\hline & & 1.483 & $(0.046)$ \\
\hline \multirow[t]{2}{*}{0.569} & $(0.002)$ & & \\
\hline & & 2.136 & $(<0.001)$ \\
\hline 2.04 & $(0.014)$ & & \\
\hline $1.38 \mathrm{I}$ & $(0.03)$ & 1.499 & $(0.009)$ \\
\hline 0.702 & $(0.038)$ & & \\
\hline 1.853 & $(0.01)$ & & \\
\hline $0.36 \mathrm{I}$ & $(<0.001)$ & & \\
\hline \multirow[t]{2}{*}{1.754} & $(0.008)$ & & \\
\hline & $(<0.00 \mathrm{I})$ & & \\
\hline 1.723 & $(0.003)$ & & \\
\hline 1.521 & $(0.045)$ & & \\
\hline 1.896 & $(0.02)$ & & \\
\hline 0.605 & $(<0.001)$ & & \\
\hline 0.592 & $(0.026)$ & & \\
\hline \multirow[t]{2}{*}{0.677} & $(0.016)$ & 1.488 & $(0.014)$ \\
\hline & & 1.496 & $(0.025)$ \\
\hline
\end{tabular}


putative exported protein

[28]) that are transcription

YPTBI66

YPOI789

YPTBI 668 (invA)

putative acyl carrier protein

or 1234

putative membran

YPTBI705

YPTBI705

putative invasin

YPTBI722

YPOI850

putative phage minor tail protein

1.671
1.57

1.638

0.5

1.794

0.397

$(<0.001)$

YPTB 1734

YPOI864

hypothetical protein

YPTBI752

conserved hypothetical protein

0.679

1.593

$(0.045)$

YPTB 1785

Oprotein [Enterobacteria phage 186]

0.49

$(0.003)$

gb|AAC34159.1| (U32222)...

or4I45 hypothetical protein

0.453

$(0.01)$

YPTBI786

or4I44

hypothetical protein

YPTBI798 (yfdM) or 1305 conserved hypothetical protein

1.506

hypothetical protein

0.279

hypothetical protein

YPTB 1802

YPTBI8I5

YPTBI82I

YPTB 1822

YPTBI826

YPTB 1850

YPTB 1858

YPTB 1862

YPTBI884

YPTB 1887

YPTBI893

YPTB 1980

YPTBI 986

YPTB। 987

YPTB 1996

YPTB2000

YPTB2092

YPTB2114

YPTB2 48

YPTB2I5I (osmB)

YPTB2219

YPTB2227

YPTB2229

YPTB2237 (asr)

YPTB2269 (pspB)

YPTB2334

YPTB2353 (yfeE)

YPTB2358 (pelY)

YPTB2363

YPTB2387

YPTB2393

or 1324

putative phage protein

YPTB I82I putative acyl carrier protein

or4135 putative membrane protein

or 1333 bacteriophage hypothetical protein

or4II4 gPR [Enterobacteria phage P2]

sp|P36933|VPR_BPP2 tAIL COMPLE...

$(0.049)$

$(0.031)$
$(<0.001)$

$(0.002)$

or4106 similar to $V$ protein phage 186

or4102 putative phage replication protein

orl358 possible MFS Superfamliy multidrug-efflux

transporter

or I36I hypothetical protein

YPOI874 conserved hypothetical protein

YPOI987 hypothetical protein (pseudogene. IS285)

YPO 1994

YPOI995

hypothetical protein

hypothetical protein

$(<0.001)$

$(0.043)$

$(<0.001)$

0.449

1.57

1.57
1.638

$(0.01)$

$(0.037)$

$(0.049)$

YPO2004

YPO2012

putative membrane protein

putative membrane protein

putative exported protein

YPO2191 hypothetical protein

YPO2226

hypothetical protein

YPO2229 osmotically inducible lipoprotein B precursoR

$(0.031)$

1.605

$(0.042)$

hypothetical protein

putative exported protein

YPO2307 conserved hypothetical protein

YPO2318 putative acid shock protein

YPO2350 phage shock protein B

YPO2426 putative exported protein

YPO2445 putative yfeABCD locus regulatoR

YPOI723 periplasmic pectate lyase precursoR

YPOI7I8 putative exported protein

YPOI694 conserved hypothetical protein

YPOI686

putative exported protein

putative membrane protein

0.536

$(0.011)$

1.593

$(0.034)$

0.649

0.57

0.256

0.671

0.28

I.855

2.229

1.37

0.708

1.983

1.628

1.526

1.794

YPOI652 


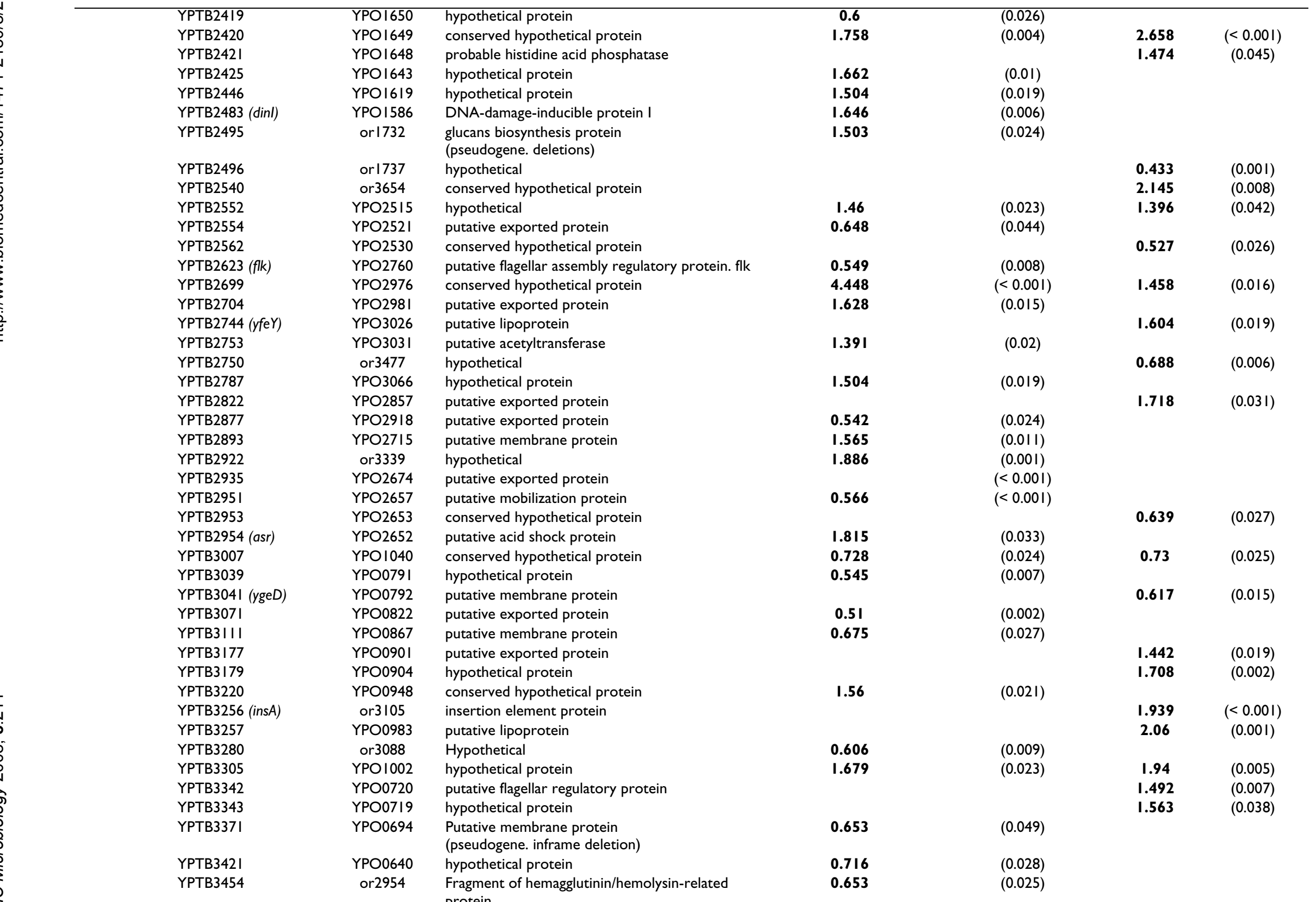




\begin{tabular}{|c|c|c|}
\hline YPTB3458 & or2950 & hypothetical \\
\hline YPTB3504 & YPO3559 & putative exported protein \\
\hline YPTB3534 & YPO3699 & putative exported protein \\
\hline YPTB355I & YPO368I & Insecticidal toxin $\mathrm{TcaA}$ \\
\hline YPTB3556 & YPO3675 & putative exported protein \\
\hline YPTB3627 & YPO360I & conserved hypothetical protein \\
\hline YPTB364I (malM) & YPO37IO & maltose operon periplasmic protein \\
\hline YPTB3769 (feoC) & YPO0I3I & ferrous iron transport protein $C$ \\
\hline YPTB3770 & YPO0I30 & putative exported protein \\
\hline YPTB378I & YPO3935 & putative membrane protein \\
\hline YPTB3789 & or2712 & putative invasin \\
\hline YPTB38II (uspB) & YPO3969 & universal stress protein $B$ \\
\hline YPTB3834 (pe/Y) & YPO3994 & periplasmic pectate lyase precursoR \\
\hline YPTB3835 & YPO3995 & putative exported protein \\
\hline YPTB3855 & YPO4020 & putative membrane protein \\
\hline YPTB3893 & YPO4040 & putative exported protein \\
\hline YPTB3908 & YPO408I & putative membrane protein \\
\hline YPTB3917 (yiaF) & YPO4070 & putative exported protein \\
\hline YPTB3922 & YPO4064 & hypothetical protein \\
\hline YPTB3923 & YPO4063 & putative membrane protein \\
\hline YPTB3944 & or2545 & hypothetical protein_ \\
\hline \multicolumn{3}{|c|}{ slational modification, protein turnover, chaperones } \\
\hline YPTB0404 (groES) & YPO0350 & $10 \mathrm{kDa}$ chaperonin \\
\hline YPTB0427 (hflK) & YPO0375 & $\begin{array}{l}\text { putative membrane protein } \\
\text { (pseudogene. inframe deletion) }\end{array}$ \\
\hline YРTB0494 & YPO3480 & conserved hypothetical protein \\
\hline YРTB0495 & YPO3479 & putative protease \\
\hline YPTB05।8 (nrdG) & YPO3455 & $\begin{array}{l}\text { anaerobic ribonucleoside-triphosphate reductase } \\
\text { Activating protein }\end{array}$ \\
\hline YPTB06/2 (dnaK) & YPO0469 & chaperone protein DnaK \\
\hline YPTB0647 (clpB) & YPO0506 & putative Clp ATPase \\
\hline YPTB0774 (pcm) & YPO3357 & protein-L-isoaspartate O-methyltransferase \\
\hline YPTB0925 (ahpC) & YPO3।94 & putative alkyl hydroperoxide reductase subunit c \\
\hline YPTB0948 (суоE) & YPO3168 & protoheme IX farnesyltransferase \\
\hline YPTB0958 (tig) & YPO3।58 & Trigger factoR \\
\hline YPTB0995 (htpG) & YPO3।I9 & heat shock protein HtpG \\
\hline YPTBI025 & YPO3083 & conserved hypothetical protein \\
\hline YPTBI026 (ybbN) & YPO3082 & putative thioredoxin \\
\hline YPTBI034 (ppiB) & YPO3074 & peptidyl-prolyl cis-trans isomerase B \\
\hline YPTBII4I & YPOII07 & heat shock protein GrpE \\
\hline YPTB। 406 (pfIA) & YPOI38I & pyruvate formate-lyase I activating enzyme \\
\hline YPTB।87I & orl348 & similar to hypothetical bacteriophage P27 protein \\
\hline YPTB। 945 & YPOI947 & putative thioredoxin \\
\hline YPTB2070 (dsbB) & YPO2I4I & disulfide bond formation protein B \\
\hline YPTB2084 & YPO2I58 & conserved hypothetical protein \\
\hline YPTB226I (tpx) & YPO2342 & thiol peroxidase \\
\hline YPTB2297 & YPO2383 & conserved hypothetical protein \\
\hline
\end{tabular}

\begin{tabular}{|c|c|c|c|}
\hline & & 1.92 & $(0.005)$ \\
\hline \multirow[t]{4}{*}{0.483} & $(<0.001)$ & & \\
\hline & & 0.676 & $(0.038)$ \\
\hline & & 0.619 & $(0.047)$ \\
\hline & & 0.637 & $(0.043)$ \\
\hline 0.595 & $(0.006)$ & & \\
\hline 0.379 & $(<0.001)$ & & \\
\hline \multirow[t]{10}{*}{1.899} & $(<0.001)$ & & \\
\hline & & 0.43 & $(<0.001)$ \\
\hline & & 0.717 & $(0.036)$ \\
\hline & & 0.614 & $(0.01)$ \\
\hline & & 0.665 & $(0.04)$ \\
\hline & & 2.081 & $(0.001)$ \\
\hline & & 1.804 & $(0.038)$ \\
\hline & & 0.422 & $(<0.001)$ \\
\hline & & 0.487 & $(<0.001)$ \\
\hline & & 1.408 & $(0.01)$ \\
\hline \multirow[t]{3}{*}{1.554} & $(0.016)$ & 0.701 & $(0.047)$ \\
\hline & & 1.409 & $(0.046)$ \\
\hline & & 1.53 & $(0.041)$ \\
\hline 0.593 & $(0.016)$ & & \\
\hline \multirow[t]{2}{*}{0.683} & $(0.029)$ & 1.445 & $(0.035)$ \\
\hline & & 0.619 & $(0.033)$ \\
\hline 0.444 & $(<0.001)$ & & \\
\hline 0.328 & $(<0.001)$ & & \\
\hline 0.439 & $(0.001)$ & & \\
\hline 0.73 & $(0.049)$ & 0.693 & $(0.025)$ \\
\hline I.48I & $(0.047)$ & 0.402 & $(<0.001)$ \\
\hline \multirow[t]{2}{*}{0.62} & $(0.014)$ & & \\
\hline & & 0.545 & $(<0.001)$ \\
\hline \multirow[t]{5}{*}{1.422} & $(0.039)$ & & \\
\hline & & 0.607 & $(0.008)$ \\
\hline & & 0.569 & $(0.004)$ \\
\hline & & 0.66 & $(0.014)$ \\
\hline & & 0.715 & $(0.019)$ \\
\hline 1.419 & $(0.013)$ & & \\
\hline 1.442 & $(0.048)$ & & \\
\hline 0.578 & $(0.004)$ & & \\
\hline 0.58 & $(0.001)$ & & \\
\hline 1.646 & $(0.002)$ & & \\
\hline 1.636 & $(<0.001)$ & 0.757 & $(0.023)$ \\
\hline 0.683 & $(0.003)$ & & \\
\hline \multirow[t]{2}{*}{2.414} & $(<0.001)$ & 0.527 & $(<0.001)$ \\
\hline & & 0.741 & $(0.025)$ \\
\hline
\end{tabular}




$\begin{array}{ll}\text { YPTB23II } & \text { YPO240 } \\ \text { YPTB23I2 } & \text { YPO2402 } \\ \text { YPTB23I3 } & \text { YPO240 } \\ \text { YPTB2734 (cysT) } & \text { YPO30 } \\ \text { YPTB2785 (bcp) } & \text { YPO3064 } \\ \text { YPTB2806 } & \text { YPO28 } \\ \text { YPTB2905 (pcp) } & \text { YPO2703 } \\ \text { YPTB2938 (ureD) } & \text { YPO267 } \\ \text { YPTB2939 (ureG) } & \text { YPO2670 } \\ \text { YPTB2940 (uref) } & \text { YPO266 } \\ \text { YPTB294I (ureE) } & \text { YPO2668 } \\ \text { YPTB3408 (glnE) } & \text { YPO0655 } \\ \text { YPTB34I5 (gcp) } & \text { YPO0646 } \\ \text { YPTB37I0 (fkpA) } & \text { YPO0I } 5 \\ \text { YPTB3728 } & \text { YPO0I I76 } \\ \text { YPTB3734 (ppiA) } & \text { YPO0I67 } \\ \text { YPTB3930 (fdhE) } & \text { YPO4055 }\end{array}$

conserved hypothetical protein

putative ATP-dependent transporteR

1.822

conserved hypothetical protein

2.036

2.213

$(0.001)$

sulfate transport system permease protein Cys T

1.417

bacterioferritin comigratory protein

1.417
0.674

putative heat shock protein

putative pyrrolidone-carboxylate peptidase

urease accessory protein

urease accessory protein

urease accessory protein

urease accessory protein

glutamate-ammonia-ligase adenyly|transferase

putative glycoprotease

peptidyl-prolyl cis-trans isomerase

conserved hypothetical protein

peptidyl-prolyl cis-trans isomerase A

putative formate dehydrogenase formation

protein

0.674
1.608

0.377

0.293

0.268

0.347

1.792

0.568

1.988

0.757

0.556

(0.002)

$(0.033)$

$(0.027)$

$(0.016)$

$(<0.001)$

$(<0.001)$

$(<0.001)$

$(<0.001)$

$(0.046)$

$(0.009)$

$(0.002)$
$(0.015)$

$(0.015)$

0.61

$(0.007)$

$(<0.001)$

$(<0.001)$

$(0.03 \mathrm{I})$

P: inorganic ion transport and metabolism

YPTB007I (cpxP)

YPO0075

putative exported protein

YPTB0336 (hmuV)

YPTB0336 (hmuV)
YPTB0338 (hmuT)

YPTB0339 (hmuS)

YPO3762

Trk system potassium uptake protein TrkH

0.634

hemin transport system ATP-binding protein

YPO028I hemin-binding periplasmic protein

YPTB0340 (hmuR)

hemin transport protein

YPO0283 hemin receptor precursoR

YPTB0343

YPTB0354 (terB)

YPTB037I

conserved hypothetical protein

YPO0285 conserved hypothetical protein

YPTB05I6 (phnG)

putative regulatory protein

YPO3457 PhnG protein

YPO3452 putative ABC transporter transporter. ATP-

binding protein

YPTB0594 YPO045I

YPTB0662 (thiP)

YPTB0739 (fhuC)

YPTB0740 (fhuD)

YPTB0790 (yhjA)

YPTB08II (katY)

YPTB0986

YPTBI246 (katA)

YPTBI34I

YPO0521

putative cation-transporting P-type ATPase

thiamine transport system permease protein

YPO3392 ferrichrome transport ATP-binding protein FhuC

ferrichrome-binding periplasmic protein

1.666

1.684

1.577

7.426

1.774

0.409

1.713

1.679

0.653

1.973

1.932

1.835

0.479

YPO3342 putative cytochrome $C$ peroxidase

0.602

YPO3319 catalase-peroxidase

YPO3130 conserved hypothetical protein

YPOI207 catalase

0.324

putative periplasmic substrate-binding transport

3.085

2.467 protein

YPTBI343 (yiuC)

YPOI312

putative siderophore $A B C$ transporter. ATP-

0.563

putative formate transporter I

YPTBI 409 (focA)

YPOI 384

YPOI537

putative iron-siderophore receptoR

2.609

YPOI783 ferritin

YPTBI659 (ftnA)

0.18

$(0.018)$

$(0.003)$

(0.015)

$(0.021)$

$(<0.001)$

(0.009)

$(<0.001)$

$(0.016)$

$(0.029)$

$(0.046)$

$(0.003)$

$(0.046)$

(0.02I)

$(<0.00 \mathrm{I})$

(0.008)

$(<0.001)$

$(<0.001)$

$(<0.001)$

$(0.005)$

$(<0.001)$

$(<0.001)$
2.344

$0.337 \quad(<0.001)$

$0.652 \quad(0.01)$

$0.605 \quad(0.019)$

$0.666 \quad(0.038)$

0.504

$(0.002)$

1.574

$(0.035)$

$(<0.001)$

$1.749(0.003)$

1.638

(0.013)

$\begin{array}{ll}0.669 & (0.039)\end{array}$ 


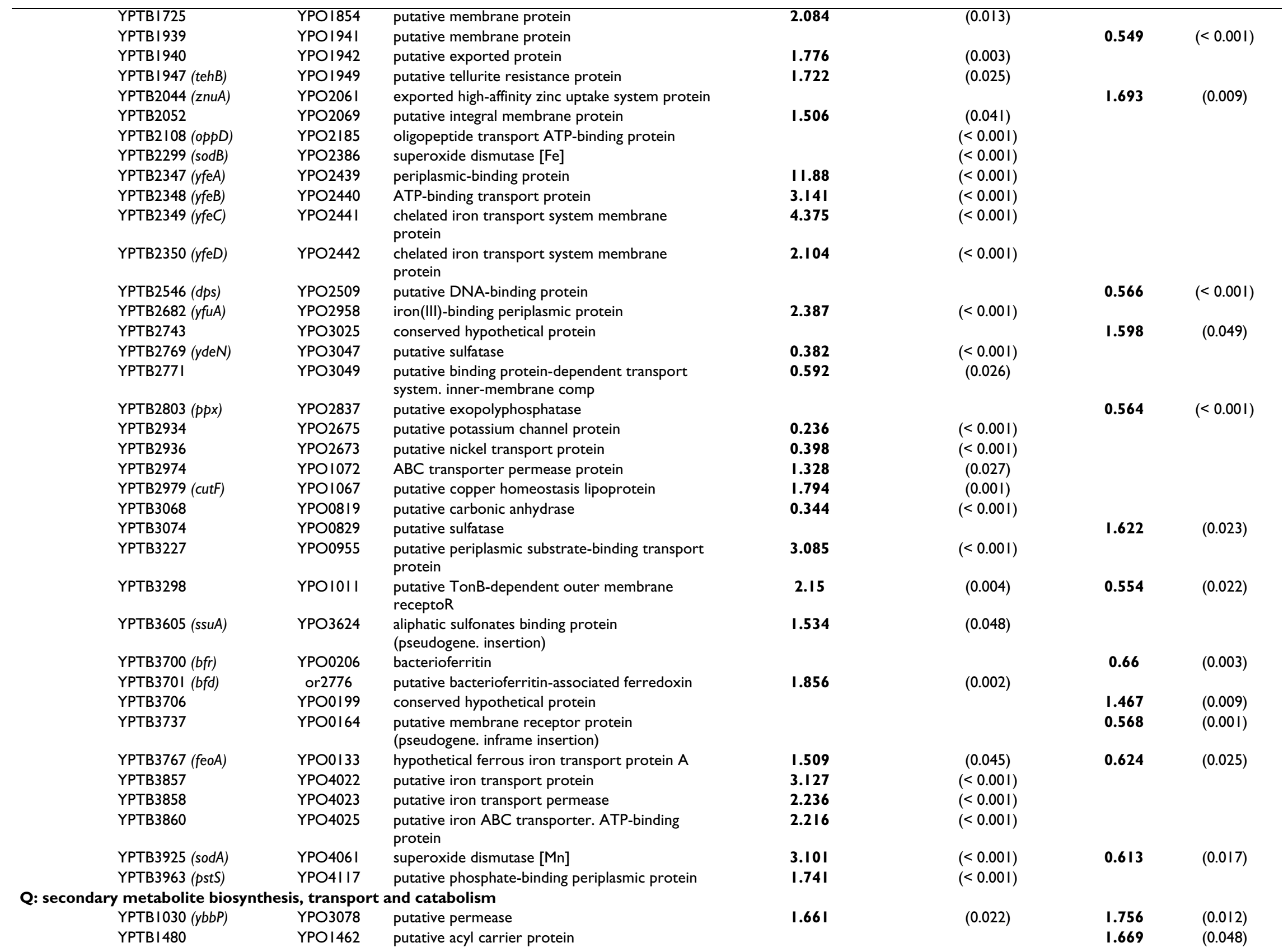




\begin{tabular}{|c|c|c|}
\hline YPTBI544 (ysuG) & YPOI532 & putative siderophore biosynthetic enzyme \\
\hline YPTBI550 & YPOI538 & putative siderophore biosynthetic enzyme \\
\hline YPTB।596 (irp2) & YPOI9II & yersiniabactin biosynthetic protein \\
\hline YPTB 1966 (hutl) & YPOI972 & imidazolonepropionase \\
\hline YPTB2064 & YPO2082 & $\begin{array}{l}\text { putative fumarylacetoacetate hydrolase family } \\
\text { protein }\end{array}$ \\
\hline YPTB2470 (acpP) & YPOI600 & acyl carrier protein \\
\hline YPTB247I (fabG) & YPOI599 & 3-oxoacyl-[acyl-carrier protein] reductase \\
\hline YPTB256I (menF) & YPO2528 & menaquinone-specific isochorismate synthase \\
\hline YPTB2626 (fabB) & YPO2757 & 3-oxoacyl-[acyl-carrier-protein] synthase I \\
\hline YPTB3258 (yspl) & YPO0984 & $\mathrm{N}$-acylhomoserine lactone synthase Yspl \\
\hline YPTB3263 (iucA) & YPO0989 & aerobactin synthetase (subunit alpha) \\
\hline YPTB3265 (iucC) & YPO0992 & aerobactin synthetase (subunit beta) \\
\hline YPTB3266 (iucD) & YPO0993 & putative siderophore biosynthesis protein lucD \\
\hline YPTB3297 & YPO0777 & putative peptide/polyketide synthase subunit \\
\hline \multicolumn{3}{|c|}{ R: general function prediction only } \\
\hline YPTB0026 & YPO0027 & conserved hypothetical protein \\
\hline YPTB0057 (tdh) & YPO0060 & threonine 3-dehydrogenase \\
\hline YPTB0063 (secB) & YPO0067 & protein-export protein \\
\hline YPTB007I (срхP) & YPO0075 & putative exported protein \\
\hline YPTB0I56 & YPO388I & putative chaperone protein \\
\hline YPTB0I58 & YPO3879 & putative outer membrane usher protein \\
\hline YPTB022I (ftsY) & YPO38I4 & $\begin{array}{l}\text { cell division protein } \\
\text { (pseudogene. inframe deletion) }\end{array}$ \\
\hline YPTB0257 (aarF) & YPO3779 & ubiquinone biosynthesis protein \\
\hline YPTB0258 (tatA) & YPO3778 & Sec-independent protein translocase protein tat $\mathrm{A}$ \\
\hline YРTB0327 & YPO0270 & putative type III secretion apparatus protein \\
\hline YРTB033। & YPO0274 & putative integral membrane protein \\
\hline YPTB0353 (terA) & YPO0295 & putative tellurite resistance protein \\
\hline YРTB0359 & YPO0302 & putative outer membrane fimbrial usher protein \\
\hline YPTB0374 (qor) & YPO0319 & quinone oxidoreductase \\
\hline YPTB0448 & YPO3528 & putative exported protein \\
\hline YPTB0466 & YPO3510 & putative membrane protein \\
\hline YPTB0493 (ibeB) & YPO348I & probable outer membrane efflux lipoprotein \\
\hline YPTB0576 (osmY) & YPO043। & osmotically inducible protein $Y$ \\
\hline YPTB0706 (hofB) & YPO3426 & putative type II secretion system protein \\
\hline YPTB0808 & YPO3322 & conserved hypothetical protein \\
\hline YPTB0832 (corE) & YPO3297 & putative membrane protein \\
\hline YPTB0839 (dcuB) & YPO3288 & $\begin{array}{l}\text { anaerobic C4-dicarboxylate transporter } \\
\text { (pseudogene. F/S) }\end{array}$ \\
\hline YРTB0878 & or0629 & 5-methylthioribose kinase \\
\hline YРTВ0929 (уајС) & YPO3190 & putative membrane protein \\
\hline YPTB0965 & YPO3I5I & conserved hypothetical protein \\
\hline YPTBI06I (уарC) & YPO2796 & putaive autotransporter protein \\
\hline YPTBIIII & YPO2618 & conserved hypothetical protein \\
\hline YPTBII55 & YPOII20 & conserved hypothetical protein \\
\hline YPTBI I59 (tolB) & YPOII24 & TolB colicin import protein \\
\hline
\end{tabular}

\begin{tabular}{|c|c|c|c|}
\hline 2.403 & $(0.005)$ & & \\
\hline 8.255 & $(<0.001)$ & 0.649 & $(0.048)$ \\
\hline 1.526 & $(0.029)$ & & \\
\hline \multirow[t]{7}{*}{0.632} & $(0.004)$ & & \\
\hline & & 0.73 & $(0.018)$ \\
\hline & & 0.661 & $(0.002)$ \\
\hline & & 0.573 & $(0.002)$ \\
\hline & & 0.522 & $(0.011)$ \\
\hline & & 0.605 & $(0.009)$ \\
\hline & & 0.494 & $(0.032)$ \\
\hline 3.789 & $(<0.001)$ & & \\
\hline 2.601 & $(<0.001)$ & & \\
\hline $2 .|5|$ & $(0.002)$ & & \\
\hline \multirow[t]{2}{*}{2.142} & $(<0.001)$ & & \\
\hline & & 0.616 & $(0.018)$ \\
\hline \multirow[t]{3}{*}{0.663} & $(0.04 I)$ & & \\
\hline & & 0.683 & $(0.012)$ \\
\hline & & 0.337 & $(<0.001)$ \\
\hline \multirow[t]{3}{*}{0.657} & $(0.01)$ & & \\
\hline & & 1.626 & $(0.016)$ \\
\hline & & 0.71 & $(0.035)$ \\
\hline 0.68 & $(0.048)$ & & \\
\hline \multirow[t]{4}{*}{0.685} & $(0.003)$ & & \\
\hline & & 0.658 & $(0.0 \mid 4)$ \\
\hline & & 2.083 & $(<0.001)$ \\
\hline & & 0.565 & $(<0.001)$ \\
\hline 1.398 & $(0.049)$ & & \\
\hline 1.393 & $(0.04)$ & & \\
\hline 0.45 I & $(<0.001)$ & & \\
\hline 1.768 & $(0.019)$ & & \\
\hline 1.863 & $(0.015)$ & & \\
\hline 3.79 & $(<0.001)$ & 0.421 & $(0.001)$ \\
\hline II I & $(0.043)$ & & \\
\hline 0.555 & $(0.031)$ & & \\
\hline 1.401 & $(0.011)$ & & \\
\hline 0.442 & $(0.001)$ & & \\
\hline 1.955 & $(0.029)$ & & \\
\hline \multirow{2}{*}{1.526} & $(0.047)$ & & \\
\hline & & 1.553 & $(0.047)$ \\
\hline 1.82 & $(0.003)$ & & \\
\hline 0.577 & $(0.001)$ & & \\
\hline 1.404 & $(0.003)$ & & \\
\hline 1.46 & $(0.025)$ & & \\
\hline
\end{tabular}




\begin{tabular}{|c|c|c|}
\hline YPTBII94 & YPOII63 & putative membrane protein \\
\hline YPTB I 210 & or4494 & $\begin{array}{l}\text { possible } A B C \text { transporter multidrug efflux pump. } \\
\text { permease subunit }\end{array}$ \\
\hline YPTBI32I & YPOI 289 & conserved hypothetical protein \\
\hline YPTB।335 (psaB) & YPOI304 & chaperone protein PsaB precursoR \\
\hline YPTBI5I2 & YPOI496 & putative heme-binding protein \\
\hline YPTBI5I3 & YPOI497 & $\mathrm{ABC}$ transporter ATP-binding protein \\
\hline YPTBI540 (ysuF) & YPOI528 & putative ferric iron reductase \\
\hline YPTBI 646 (hpaC) & YPOI770 & $\begin{array}{l}\text { 4-hydroxyphenylacetate 3-monooxygenase } \\
\text { coupling protein }\end{array}$ \\
\hline YPTBI660 & YPOI784 & putative copper resistance protein \\
\hline YPTB। 680 (flg) & YPOI807 & flagellar protein Flg \\
\hline YPTBI693 & YPOI820A & \\
\hline YPTBI695 (fliN) & YPOI822 & flagellar motor switch protein FliN \\
\hline YPTBI728 (wrbA) & YPOI857 & trp repressor binding protein \\
\hline YPTB I 733 (ydgC) & YPOI863 & putative membrane protein \\
\hline YPTB।919 & YPOI920 & probable fimbrial usher protein \\
\hline YPTB।944 & YPOI946 & ABC transporter. ATP-binding protein \\
\hline YPTB।985 & YPOI993 & putative dehydrogenase \\
\hline YPTB2019 & YPO2037 & conserved hypothetical protein \\
\hline YPTB2 I0I (hns) & YPO2I75 & Hns DNA binding protein \\
\hline YPTB2169 & orl554 & $\begin{array}{l}\text { putative toxin transport protein (pseudogene. F/ } \\
\text { S) }\end{array}$ \\
\hline YPTB2289 & YPO2375 & putative aldo/keto reductase \\
\hline YPTB2291 & YPO2377 & putative membrane protein \\
\hline YPTB2345 (marC) & YPO2437 & multiple antibiotic resistance protein \\
\hline YPTB2368 (ogl) & YPOI7I3 & oligogalacturonate lyase \\
\hline YPTB2390 & YPOI689 & putative lipoprotein \\
\hline YPTB2452 (ycfL) & YPOI6I2 & putative lipoprotein \\
\hline YPTB2459 & or3719 & hypothetical \\
\hline YPTB247I (fabG) & YPOI599 & 3-oxoacyl-[acyl-carrier protein] reductase \\
\hline YPTB2488 & YPO245I & conserved hypothetical protein \\
\hline YPTB2492 & or3693 & conserved hypothetical protein \\
\hline YPTB2553 & or3647 & conserved hypothetical protein \\
\hline YPTB2604 & or3598 & conserved hypothetical (pseudogene. F/S) \\
\hline YPTB2646 (ccmD) & or3557 & putative heme exporter protein $\mathrm{D}$ \\
\hline YPTB2722 & YPO300I & $\begin{array}{l}\text { putative pyridine nucleotide-disulphide } \\
\text { oxidoreductase }\end{array}$ \\
\hline YPTB2723 & YPO3002 & putative permease \\
\hline YPTB2727 & YPO3007 & putative membrane protein \\
\hline YPTB2753 & YPO3031 & putative acetyltransferase \\
\hline YPTB2837 (engA) & YPO2875 & putative GTP-binding protein \\
\hline YPTB2843 & YPO288I & putative fimbrial biogenesis protein \\
\hline YPTB289I (lepB) & YPO27I7 & signal peptidase I \\
\hline YPTB2902 & YPO2706 & conserved hypothetical protein \\
\hline YPTB3।I6 & or3203 & hypothetical protein \\
\hline YРTB3। 76 & YPO0900 & putative hemolysin III \\
\hline
\end{tabular}

0.669
1.662
0.216
2.456
1.878
4.019
1.613
3.934

$(0.026)$

$(<0.001)$

$(<0.001)$

$(0.009)$

$(<0.00 \mathrm{I})$

0.453

$(0.001)$

$(<0.00 \mathrm{I})$

0.703

$(0.017)$

$1.906 \quad(0.01)$

$2.053 \quad(0.011)$

I.40I $(0.006)$

$0.626 \quad(0.001)$

1.957

$(0.003)$

$\begin{array}{ll}1.461 & (0.019)\end{array}$

$1.588 \quad(0.03)$

1.56

1.586

$(0.007)$

$(0.021)$

1.549

0.405

$(0.001)$

1.508

$(0.027)$

$(0.006)$

$(0.018)$

$(0.022)$

(0.045)

$(0.032)$

$(0.046)$

1.312

$(<0.001)$

0.573

0.602

$(0.009)$

0.67I $(0.026)$

$0.573-(0.006)$

1.86

$(0.006)$
$(0.004)$

0.36

$(<0.001)$

1.529

$(0.038)$

1.328

1.932

$(0.036)$

1.391

$(0.008)$

0.573

1.527

(0.015)

0.549

$(0.032)$

$(0.026)$

$\begin{array}{ll}0.686 & (0.022) \\ \text { I.5 I8 } & (0.035) \\ \text { I.898 } & (0.018) \\ 0.556 & (0.022) \\ \text { I.4I5 } & (0.038)\end{array}$




\begin{tabular}{|c|c|c|c|c|c|c|}
\hline YPTB3223 & YPO095I & Putative methyltransferase & & & 0.612 & $(0.023)$ \\
\hline YPTB3238 & YPO0966 & putative kinase & 0.505 & $(0.032)$ & & \\
\hline YPTB3285 & or3082 & Putative autotransporter secreted protein & & & 1.593 & $(0.028)$ \\
\hline YPTB329| & YPO077I & $A B C$-transporter transmembrane protein & 1.705 & $(0.014)$ & & \\
\hline YPTB3357 & YPO0704 & flagellar assembly protein & $0.6 \mathrm{II}$ & $(0.049)$ & & \\
\hline YPTB338I & YPO0684 & putative membrane protein & & & 1.67 & $(0.014)$ \\
\hline YPTB3382 (exbD) & YPO0683 & ExbD/TolR-family transport protein & 9.812 & $(<0.00 \mathrm{I})$ & & \\
\hline YPTB3383 (exbB) & YPO0682 & MotA/TolQ/ExbB proton channel family protein & 4.164 & $(<0.00 \mathrm{I})$ & & \\
\hline YPTB3388 & YPO0676 & putative aldo/keto reductase family protein & & & 1.632 & $(0.042)$ \\
\hline YPTB3438 & YPO0617 & putative membrane protein & 1.993 & $(0.004)$ & & \\
\hline YPTB3464 & YPO0595 & conserved hypothetical protein & 0.528 & $(0.005)$ & & \\
\hline YРTB3493 & YPO3548 & putative exported protein & 0.602 & $(0.005)$ & & \\
\hline YPTB3496 & YPO355I & putative exported protein & & & 0.553 & $(<0.001)$ \\
\hline YPTB3558 (tldD) & YPO3672 & putative modulator of DNA gyrase & & & 0.702 & $(0.025)$ \\
\hline YPTB3568 & YPO3662 & conserved hypothetical protein & & & 1.489 & $(0.008)$ \\
\hline YPTB3659 & YPO0247 & putative transferase & 1.289 & $(0.029)$ & & \\
\hline YPTB3745 (gph) & YPOOI56 & phosphoglycolate phosphatase & 0.596 & $(0.022)$ & & \\
\hline YPTB3757 & YPO0I44 & putative hydrolase & 1.58 & $(0.013)$ & & \\
\hline YPTB3879 & or2640 & $\begin{array}{l}\text { possible type I restriction enzyme (restriction } \\
\text { subunit) }\end{array}$ & 1.554 & $(0.044)$ & & \\
\hline YРTB3896 & YPO4044 & fimbrial protein & & & 1.644 & $(0.021)$ \\
\hline YPTB3939 & YPO4093 & putative haloacid dehalogenase-like hydrolase & 1.753 & $(0.02)$ & & \\
\hline YPTB3948 (yidC) & YPO4I02 & probable membrane protein & 0.666 & $(0.024)$ & 0.645 & $(0.016)$ \\
\hline YPTB3953 (yieG) & YPO4I07 & Xanthine/uracil permeases family protein & 0.638 & $(0.046)$ & 1.583 & $(0.042)$ \\
\hline \multicolumn{7}{|l|}{ S: function unknown } \\
\hline YPTB00I5 (mobA) & YPO00I3A & $\begin{array}{l}\text { molybdopterin-guanine dinucleotide biosynthesis } \\
\text { protein A }\end{array}$ & & & 0.703 & $(0.032)$ \\
\hline YРTB0020 & YPO0020 & conserved hypothetical protein & 0.493 & $(<0.001)$ & & \\
\hline YРTВ0040 & YPO0043 & conserved hypothetical protein & 0.705 & $(0.029)$ & 0.656 & $(0.011)$ \\
\hline YРTB0089 & YPO0093 & conserved hypothetical protein & 1.682 & $(<0.00 \mathrm{l})$ & 0.681 & $(0.008)$ \\
\hline YPTBOI 96 & or0133 & conserved hypothetical protein & & & 3.061 & $(<0.001)$ \\
\hline YPTB0219 & YPO38I6A & & & & 1.383 & $(0.046)$ \\
\hline YРTB0296 & YPO3732 & conserved hypothetical protein & & & 0.558 & $(<0.001)$ \\
\hline YРTВ0378 & YPO0323 & conserved hypothetical protein & 1.483 & $(0.016)$ & & \\
\hline YРTB0454 & YPO3522 & conserved hypothetical protein & 1.472 & $(0.03)$ & & \\
\hline YPTB0478 & YPO3498 & conserved hypothetical protein & 0.734 & $(0.038)$ & & \\
\hline YРTB0506 & or0367 & conserved hypothetical protein & 0.541 & $(0.013)$ & & \\
\hline YРTB0547 & YPO0407 & conserved hypothetical protein & & & 1.999 & $(<0.001)$ \\
\hline YРTB0589 & YPO0445 & conserved hypothetical protein & & & 1.579 & $(0.007)$ \\
\hline YPTB0600 (creA) & YPO0 0457 & putative exported protein & 1.924 & $(<0.001)$ & & \\
\hline YPTB0627 & YPO0485 & putative membrane protein & & & 1.523 & $(0.018)$ \\
\hline YРTB0639 & YPO0498 & hypothetical protein & & & 0.302 & $(<0.001)$ \\
\hline YРTB0640 & YPO0499 & hypothetical protein & & & & $(<0.001)$ \\
\hline YPTB064I & YPO0500 & conserved hypothetical protein & & & & $(<0.001)$ \\
\hline YРTB0642 & YPO050I & conserved hypothetical protein & & & 0.346 & $(<0.001)$ \\
\hline YРTВ0643 & YPO0502 & conserved hypothetical protein & & & & $(<0.001)$ \\
\hline YРTB0644 & YPO0503 & conserved hypothetical protein & & & 0.702 & $(0.012)$ \\
\hline
\end{tabular}

YPO0503

conserved hypothetical protein 


\begin{tabular}{|c|c|c|}
\hline YPTB0646 & YPO0505 & conserved hypothetical protein \\
\hline YPTB0648 & YPO0507 & conserved hypothetical protein \\
\hline YPTB0649a & YPO0508 & hypothetical protein \\
\hline YPTB0650 & YPO05I0 & hypothetical protein \\
\hline YPTB0653 & YPO05I2 & putative lipoprotein \\
\hline YРTB0654 & YPO05I3 & conserved hypothetical protein \\
\hline YPTB0655 & YPO05I4 & putative OmpA-family membrane protein \\
\hline YРTB0679 & YPO0546 & conserved hypothetical protein \\
\hline YPTB070I & YPO343I & conserved hypothetical protein \\
\hline YPTB0744 & YPO3387 & conserved hypothetical protein \\
\hline YPTB0876 & or0627 & methionine salvage pathway enzyme E-2/E-2' \\
\hline YPTB0976 (ybaY) & YPO3।40 & putative lipoprotein \\
\hline YPTBI02I & YPO3087 & conserved hypothetical protein \\
\hline YPTB 057 & YPO280I & putative membrane protein \\
\hline YPTBI078 & YPO2585 & putative carbohydrate kinase \\
\hline YPTBI085 & YPO2592 & putative membrane protein \\
\hline YPTBII6I & YPOII26 & putative exported protein \\
\hline YPTB 1215 & YPOII74 & hypothetical protein \\
\hline YPTBI 222 & YPOII8I & putative membrane protein \\
\hline YPTBI 227 & YPOII86 & conserved hypothetical protein \\
\hline YPTB 1297 & YPOI26I & conserved hypothetical protein \\
\hline YPTB। 387 & YPOI36I & putative membrane protein \\
\hline YPTBI389 & YPOI363 & putative virulence factoR \\
\hline YPTBI422 & YPOI397 & $\begin{array}{l}\text { conserved hypothetical protein } \\
\text { (pseudogene. inframe deletion) }\end{array}$ \\
\hline YPTB। 432 & YPOI408 & putative exported protein \\
\hline YPTB।499 & YPOI483 & hypothetical protein \\
\hline YPTBI504 & YPOI487 & conserved hypothetical protein \\
\hline YPTB।57I & YPOI560 & conserved hypothetical protein \\
\hline YPTB I 640 (hpaD) & YPOI764 & 3.4-dihydroxyphenylacetate 2.3-dioxygenase \\
\hline YPTB 1729 & YPOI858 & putative exported protein \\
\hline YPTB।90I & orl366 & conserved hypothetical protein \\
\hline YPTB।902 & YPOI882 & conserved hypothetical protein \\
\hline YPTB।94I & YPOI943 & putative membrane protein \\
\hline YPTB2085 & YPO2159 & conserved hypothetical protein \\
\hline YPTB2I46 & YPO2224 & putative membrane protein \\
\hline YPTB2214 & YPO229I & putative virulence factoR \\
\hline YPTB2234 & YPO23I5 & putative exported protein \\
\hline YPTB2265 & YPO2347 & putative membrane protein \\
\hline YPTB23।4 & YPO2404 & conserved hypothetical protein \\
\hline YPTB2352 & YPO2444 & conserved hypothetical protein \\
\hline YPTB2388 & YPOI693 & conserved hypothetical protein \\
\hline YPTB2444 (ycf) & YPOI624 & putative exported protein \\
\hline YPTB248I & YPOI588 & conserved hypothetical protein \\
\hline YPTB2526 & YPO2489 & conserved hypothetical protein \\
\hline YPTB2547 & YPO25I0 & putative exported protein \\
\hline YPTB2594 & YPO2563 & conserved hypothetical protein \\
\hline
\end{tabular}

\begin{tabular}{|c|c|c|c|}
\hline & & 0.355 & $(<0.00 \mathrm{I})$ \\
\hline & & 0.679 & $(0.044)$ \\
\hline & & 0.56 & $(0.031)$ \\
\hline 1.447 & $(0.043)$ & 0.368 & $(<0.001)$ \\
\hline \multirow[t]{3}{*}{1.45} & $(0.035)$ & 0.618 & $(0.009)$ \\
\hline & & 0.364 & $(0.002)$ \\
\hline & & 0.383 & $(<0.001)$ \\
\hline 1.35 & $(0.036)$ & & \\
\hline
\end{tabular}

YPO2563

0.663

2.792

1.682

$(0.044)$

0.634

1.593

0.632

$(<0.001)$

$(<0.001)$

1.533

$(0.007)$

$1.504(0.043)$

I.394 (0.029)

$1.704(0.035)$

$0.609 \quad(0.015)$

$0.596 \quad(0.004)$

I.527 (0.047)

$0.697 \quad(0.032)$

0.659

$(0.003)$

$(0.043)$

1.803

$(0.012)$

0.671

1.491

2.062

1.34

0.625

0.704

I.5 I I

1.552

2.118

0.606

0.638

1.503

1.284

2.602

0.704

1.569
2.296

0.31

0.563
$(0.044)$

$(0.029)$

$(0.005)$

$(0.036)$

$(0.046)$

$(0.037)$

$(0.01)$

$(<0.001)$

$(0.004)$

$(0.032)$

(0.023)

$(0.008)$

$(0.04)$

$(<0.001)$

(0.017)

$(0.038)$

$(0.001)$

0.759

$(0.035)$

$(<0.001)$

$(<0.00 \mathrm{I})$
$(0.018)$

$(0.035)$

$(0.02)$ 


\begin{tabular}{|c|c|c|}
\hline YPTB2638 & YPO2745 & conserved hypothetical protein \\
\hline YPTB265I (lemA) & YPO2732 & putative exported protein \\
\hline YPTB2660 & YPO2724 & putative membrane protein \\
\hline YPTB266I & YPO2723 & $\begin{array}{l}\text { possible OmpA family } \\
\text { (pseudogene. ISI00 insertion) }\end{array}$ \\
\hline YPTB2674 & YPO2949 & hypothetical protein \\
\hline YPTB2693 & YPO2970 & putative lipoprotein \\
\hline YPTB2694 & YPO297I & putative lipoprotein \\
\hline YPTB2745 (ygiW) & YPO3027 & putative exported protein \\
\hline YPTB2907 & YPO270I & putative membrane protein \\
\hline YPTB298I & YPOI065 & conserved hypothetical protein \\
\hline YPTB3 II 7 & YPO0874 & hypothetical protein \\
\hline YPTB3I6I & or2087 & Hypothetical bacteriophage protein. \\
\hline YPTB3।86 & YPO09II & putative exported protein \\
\hline YPTB3। 87 & YPO0912 & conserved hypothetical protein \\
\hline YPTB3206 & YPO0934 & conserved hypothetical protein \\
\hline YPTB3222 & YPO0950 & conserved hypothetical protein \\
\hline YPTB330I & or2158 & putative antigenic leucine-rich repeat protein \\
\hline YPTB3403 & YPO0659 & conserved hypothetical protein \\
\hline YPTB3429 & YPO0626 & Conserved hypothetical \\
\hline YPTB3468 (hdeD) & YPO0590 & putative membrane protein \\
\hline YPTB3484 & YPO0572 & putative exported protein \\
\hline YPTB3485 (yqjD) & YPO0570 & putative membrane protein \\
\hline YPTB3486 & YPO0569A & \\
\hline YPTB35I0 & YPO3565 & putative membrane protein \\
\hline YPTB3573 (panF) & YPO3657A & sodium/pantothenate symporteR \\
\hline YPTB358I & YPO3649 & $\begin{array}{l}\text { putative gamma carboxymuconolactone } \\
\text { decarboxylase }\end{array}$ \\
\hline YPTB36I7 & or2852 & putative Rhs accessory genetic element \\
\hline YPTB3622 & YPO3607 & conserved hypothetical protein \\
\hline YPTB3748 & YPO0I53 & conserved hypothetical membrane protein \\
\hline YPTB3773 & YPO0I 27 & conserved hypothetical protein \\
\hline YPTB3897 & YPO4045 & putative membrane protein \\
\hline \multicolumn{3}{|c|}{ ransduction mechanisms } \\
\hline YPTB0022 (ntrC) & YPO0022 & nitrogen regulation protein \\
\hline YPTB0035 (spot) & YPO0038 & $\begin{array}{l}\text { guanosine-3'.5'-bisbis(diphosphate) 3'- } \\
\text { pyrophosphydrolase }\end{array}$ \\
\hline YPTB007I (cpxP) & YPO0075 & putative exported protein \\
\hline YPTB0356 (terD) & YPO0298 & tellurium resistance protein \\
\hline YPTB0357 (terE) & YPO0299 & tellurium resistance protein \\
\hline YPTB0468 (basS) & YPO3508 & two-component system sensor protein \\
\hline YPTB054I & YPO040I & putative transcriptional regulato $R$ \\
\hline YPTB0570 (hmsT) & YPO0425 & HmsT protein \\
\hline YPTB0592 & YPO0449 & putative exported protein \\
\hline YPTB060I (arcA) & YPO0458 & aerobic respiration control protein \\
\hline YPTB0734 (dksA) & YPO3397 & DnaK suppressor protein homologue \\
\hline YРTВ0789 & YPO3343 & probable extracellular solute-binding protein \\
\hline
\end{tabular}

\begin{tabular}{|c|c|c|c|}
\hline 0.483 & $(0.001)$ & & \\
\hline $0.38 I$ & $(<0.001)$ & & \\
\hline \multirow[t]{2}{*}{1.486} & $(0.038)$ & & \\
\hline & & 1.796 & $(0.048)$ \\
\hline \multirow[t]{6}{*}{1.753} & $(0.045)$ & & \\
\hline & & 0.65 & $(0.049)$ \\
\hline & & 0.454 & $(<0.001)$ \\
\hline & & 0.648 & $(0.002)$ \\
\hline & & 0.658 & $(0.038)$ \\
\hline & & 0.721 & $(0.035)$ \\
\hline \multirow[t]{4}{*}{0.675} & $(0.039)$ & & \\
\hline & & 0.64 & $(0.033)$ \\
\hline & & 1.578 & $(0.023)$ \\
\hline & & 0.612 & $(0.006)$ \\
\hline \multirow[t]{3}{*}{0.69} & (0.039) & & \\
\hline & & 0.547 & $(0.006)$ \\
\hline & & $0.58 I$ & $(0.004)$ \\
\hline 0.768 & $(0.028)$ & 0.753 & $(0.019)$ \\
\hline 0.619 & $(0.034)$ & & \\
\hline \multirow[t]{2}{*}{0.209} & $(<0.001)$ & & \\
\hline & & 0.533 & $(0.013)$ \\
\hline 0.674 & $(0.02)$ & 0.576 & $(0.002)$ \\
\hline \multirow[t]{3}{*}{0.606} & $(0.026)$ & & \\
\hline & & 0.745 & $(0.02)$ \\
\hline & & 0.732 & $(0.028)$ \\
\hline 0.573 & $(0.01)$ & & \\
\hline \multirow[t]{3}{*}{0.632} & $(0.037)$ & & \\
\hline & & 0.589 & $(0.014)$ \\
\hline & & 0.614 & $(0.033)$ \\
\hline \multirow[t]{3}{*}{2.928} & $(<0.00 \mathrm{I})$ & & \\
\hline & & 0.609 & $(0.015)$ \\
\hline & & 0.723 & $(0.037)$ \\
\hline \multirow[t]{2}{*}{0.684} & $(0.011)$ & & \\
\hline & & 0.337 & $(<0.001)$ \\
\hline I.485 & $(0.034)$ & & \\
\hline \multirow[t]{2}{*}{1.501} & $(0.005)$ & 0.72 & $(0.019)$ \\
\hline & & 2.184 & $(0.001)$ \\
\hline 0.652 & $(0.035)$ & & \\
\hline \multirow[t]{2}{*}{0.574} & $(0.014)$ & 1.64 & $(0.026)$ \\
\hline & & 0.591 & $(0.022)$ \\
\hline \multirow[t]{2}{*}{0.465} & $(0.001)$ & & \\
\hline & & 0.508 & $(<0.001)$ \\
\hline
\end{tabular}

T: signal transduction mechanisms

$$
\text { YPTB0022 (ntrC) }
$$

YPO3343 


\begin{tabular}{|c|c|c|c|c|c|c|}
\hline YPTBI I08 $(g \ln H)$ & YPO26I5 & putative amino acid-binding protein precursoR & 0.564 & $(0.005)$ & & \\
\hline YPTB। 258 (rcsB) & YPOI218 & $\begin{array}{l}\text { probable two component response regulator } \\
\text { component B }\end{array}$ & & & 0.693 & $(0.016)$ \\
\hline YPTBI259 & YPOI219 & putative two component sensor kinase & & & 0.696 & $(0.04 I)$ \\
\hline YPTB।922 & YPOI923 & Putative sensor protein & & & $1.45 \mathrm{I}$ & $(0.044)$ \\
\hline YPTB 1957 (narX) & YPOI959 & nitrate/nitrite sensor protein & 1.83 & $(0.031)$ & & \\
\hline YPTB2099 & YPO2173 & probable response regulato $R$ & & & 1.533 & $(0.043)$ \\
\hline YPTB2I56 (cstA) & YPO2234 & putative carbon starvation protein A & 0.544 & $(0.012)$ & 0.624 & $(0.045)$ \\
\hline YPTB2222 (fnr) & YPO2300 & fumarate and nitrate reduction regulatory protein & 0.699 & $(0.001)$ & 1.584 & $(<0.00 \mathrm{I})$ \\
\hline YPTB2230 (rstA) & YPO2308 & $\begin{array}{l}\text { two-component regulatory system. response } \\
\text { regulator protein }\end{array}$ & 0.658 & $(0.024)$ & & \\
\hline YPTB2378 & YPOI703 & conserved hypothetical protein & & & $0.7 \mathrm{I}$ & $(0.022)$ \\
\hline YPTB2396 (cheZ) & YPOI68I & chemotaxis protein CheZ & & & 1.477 & $(0.027)$ \\
\hline YPTB2405 (cheA) & YPOI666 & chemotaxis protein CheA & 1.725 & $(0.015)$ & & \\
\hline YPTB2435 (phoQ) & YPOI633 & sensor protein kinase & 0.527 & $(<0.00 \mathrm{I})$ & & \\
\hline YPTB2548 $(g \ln H)$ & YPO25II & putative glutamine-binding periplasmic protein & & & 1.797 & $(0.014)$ \\
\hline YPTB2635 (sixA) & YPO2748 & putative phosphohistidine phosphatase & & & 1.508 & $(0.002)$ \\
\hline YPTB2763 (narP) & YPO304I & nitrate/nitrite response regulator protein $\mathrm{NarP}$ & & & 0.715 & $(0.043)$ \\
\hline YPTB2894 (rseC) & YPO27I4 & sigma E factor regulatory protein & & & 1.431 & $(0.034)$ \\
\hline YPTB2895 (rseB) & YPO27I3 & sigma E factor regulatory protein & & & 1.466 & $(0.04)$ \\
\hline YPTB2896 (rseA) & YPO27I 2 & sigma E factor negative regulatory protein & & & 1.652 & $(<0.001)$ \\
\hline YPTB3350 (fleR) & YPO07I2 & sigma-54 transcriptional regulatory protein & 2.134 & $(0.004)$ & & \\
\hline YPTB3408 (glnE) & YPO0653 & glutamate-ammonia-ligase adenylyltransferase & 1.792 & $(0.046)$ & & \\
\hline YPTB3410 & YPO065I & putative exported protein & 1.988 & $(<0.00 \mathrm{I})$ & & \\
\hline YPTB3463 (terX) & YPO0596 & putative tellurium resistance protein & 0.522 & $(<0.001)$ & & \\
\hline YPTB3500 (arcB) & YPO3555 & $\begin{array}{l}\text { aerobic respiration control sensor/response } \\
\text { regulatory protein }\end{array}$ & 0.674 & $(0.012)$ & & \\
\hline YPTB3566 (yhdA) & YPO3664 & putative exported protein & & & 1.836 & $(<0.001)$ \\
\hline YPTB3729 (crp) & YPO0I75 & cAMP-regulatory protein & & & 0.641 & $(<0.001)$ \\
\hline YPTB38I2 (uspA) & YPO3970 & universal stress protein $A$ & 0.291 & $(<0.00 \mathrm{I})$ & 1.554 & $(0.038)$ \\
\hline YPTB3847 (uhpA) & YPO40I2 & two-component system response regulato $R$ & & & 2.004 & $(0.006)$ \\
\hline YPTB3957 & YPO4III & putative periplasmic solute-binding protein & 1.59 & $(0.006)$ & & \\
\hline YPTB234I (infC) & YPO2432 & translation initiation factor IF-3 & & & 0.539 & $(<0.001)$ \\
\hline
\end{tabular}


Table 3: Y. pseudotuberculosis IP32953 pYV plasmid-harbored genes that are transcriptionally regulated by growth medium and/or temperature.

\begin{tabular}{|c|c|c|c|c|c|c|}
\hline \multirow{3}{*}{$\begin{array}{c}\text { Gene designation } \\
\text { pYV0013 }\end{array}$} & \multirow{3}{*}{$\begin{array}{c}\text { Genoscript spot ID } \\
\text { pCDI-yadA }\end{array}$} & \multirow{3}{*}{$\begin{array}{l}\text { Gene product/function } \\
\text { hypothetical protein }\end{array}$} & \multicolumn{4}{|c|}{ Fold ratio in gene transcription ( $p$-value) } \\
\hline & & & \multicolumn{2}{|c|}{ Human plasma/Luria Bertani Broth } & \multicolumn{2}{|c|}{$37^{\circ} \mathrm{C} / 28^{\circ} \mathrm{C}$} \\
\hline & & & I 3.528 & $(<0.001)$ & 1.577 & $(0.046)$ \\
\hline PYV00I4 & PCDI-AAC62595 & possible transposase remnant & 1.789 & $(0.025)$ & 1.884 & $(0.016)$ \\
\hline pYV00I7 & pCDI-tnpR & putative resolvase & $0.34 I$ & $(<0.001)$ & & \\
\hline pYV0020 & pCDI-sycH & putative $\mathrm{YopH}$ targeting protein & 5.088 & $(<0.001)$ & 2.715 & $(<0.00 \mathrm{I})$ \\
\hline pYV0024 & pCDI-sycE & putative YopE chaperone & $5.78 I$ & $(<0.001)$ & 2.403 & $(0.005)$ \\
\hline pYV0040 & pCDI-уорK/yopQ & $\begin{array}{l}\text { Yop targeting protein YopK, } \\
\text { YopQ }\end{array}$ & & & 1.666 & $(0.019)$ \\
\hline pYV0047 & pCDI-уорM & putative targeted effector protein & 3.468 & $(<0.001)$ & 2.252 & $(0.002)$ \\
\hline pYV0054 & pCDI-yорD & $\begin{array}{l}\text { putative Yop negative regulation/ } \\
\text { targeting component }\end{array}$ & 2.933 & $(<0.001)$ & 2.211 & $(0.004)$ \\
\hline pYV0055 & pCDI-yopB & putative Yop targeting protein & 2.816 & $(<0.00 \mathrm{I})$ & 2.196 & $(<0.00 \mathrm{I})$ \\
\hline pYV0056 & $\mathrm{pCDI}-\mathrm{lcrH}$ & low calcium response protein $\mathrm{H}$ & 3.522 & $(<0.001)$ & $\mid .85 \mathrm{I}$ & $(0.02 \mathrm{I})$ \\
\hline pYV0057 & pCDI-IcrV & $\begin{array}{l}\text { putative } V \text { antigen, antihost } \\
\text { protein/regulator }\end{array}$ & 1.904 & $(<0.001)$ & 1.637 & $(0.003)$ \\
\hline pYV0058 & pCDI-lcrG & putative Yop regulator & 1.713 & $(0.014)$ & & \\
\hline pYV0059 & PCDI-IcrR & hypothetical protein LcrR & 1.469 & $(0.001)$ & 1.849 & $(<0.00 \mathrm{I})$ \\
\hline pYV0062 & pCDI-yscX & putative type III secretion protein & 1.629 & $(0.009)$ & 1.533 & $(0.020)$ \\
\hline pYV0065 & pCDI-yopN & $\begin{array}{l}\text { putative membrane-bound Yop } \\
\text { targeting protein }\end{array}$ & 2.612 & $(<0.001)$ & 1.549 & $(0.049)$ \\
\hline pYV0067 & $\mathrm{pCDI}-\mathrm{yscN}$ & $\begin{array}{l}\text { putative Yops secretion ATP } \\
\text { synthase }\end{array}$ & 2.856 & $(<0.001)$ & 1.717 & $(0.002)$ \\
\hline pYV0068 & pCDI-yscO & putative type III secretion protein & 3.088 & $(<0.001)$ & & \\
\hline PYV0069 & PCDI-yscP & putative type III secretion protein & & & 1.593 & $(0.018)$ \\
\hline pYV0070 & pCDI-yscQ & putative type III secretion protein & 1.635 & $(0.026)$ & & \\
\hline pYV007I & PCDI-yscR & $\begin{array}{l}\text { putative Yop secretion } \\
\text { membrane protein }\end{array}$ & 1.949 & $(0.012)$ & & \\
\hline pYV0072 & pCDI-yscS & putative type III secretion protein & 2.331 & $(<0.001)$ & 1.897 & $(0.002)$ \\
\hline pYV0075 & PCDI-virG & $\begin{array}{l}\text { putative Yop targeting } \\
\text { lipoprotein }\end{array}$ & 1.957 & & & \\
\hline pYV0076 & pCDI-IcrF/virF & $\begin{array}{l}\text { putative thermoregulatory } \\
\text { protein }\end{array}$ & $1.44 \mathrm{I}$ & $(0.042)$ & & \\
\hline pYV0078 & $\mathrm{PCDI}-\mathrm{yscB}$ & hypothetical protein & 3.038 & $(0.002)$ & & \\
\hline pYV0079 & PCDI-yscC & putative type III secretion protein & 2.384 & $(0.001)$ & 2.713 & $(<0.00 \mathrm{I})$ \\
\hline PYV0080 & PCDI-yscD & putative type III secretion protein & 2.542 & $(<0.001)$ & 1.990 & $(0.005)$ \\
\hline pYV008I & PCDI-yscE & putative type III secretion protein & $2.7 I I$ & $(0.001)$ & 1.809 & $(0.032)$ \\
\hline pYV0082 & $\mathrm{pCDI}-\mathrm{yscF}$ & putative type III secretion protein & 2.117 & $(0.017)$ & & \\
\hline pYV0083 & $\mathrm{pCD} \mid-\mathrm{yscG}$ & putative type III secretion protein & 2.463 & $(<0.001)$ & & \\
\hline pYV0085 & pCDI-yscl & putative type III secretion protein & 1.864 & $(0.003)$ & & \\
\hline pYV0089 & PCDI-yscM & $\begin{array}{l}\text { putative type III secretion } \\
\text { regulatory protein }\end{array}$ & 0.679 & $(0.036)$ & & \\
\hline
\end{tabular}

that encodes catalase (a ferric enzyme involved in oxidative stress defense), whose transcription is decreased in both Y. pestis and Y. pseudotuberculosis during growth in plasma (Fig. 1). However, the increase in transcription of the bio locus (required for biotin synthesis [13]) and observed in both species) suggests that differential genetic control of a subset of iron-dependent enzymes may favor supply of this metal to the pathways that are most important for bacterial survival (and thus presumably at the expense of other, less critical ones). Furthermore, the impact of transcriptional downregulation on reorientation of metabolic fluxes may be minimized by the con- comitant activation of genes coding for isoenzymes that are better suited to this situation.

One example is that of the manganese- and iron-dependent superoxide dismutase genes (i.e sodA and $\operatorname{sod} B$ ), which are Fur-activated and -repressed, respectively (Fig. 1) in both $Y$. pestis and $Y$. pseudotuberculosis. Similarly, the class Ib ribonucleotide reductase (RNR)-encoding genes (nrdHIEF) are probably important for bacterial life in plasma, since they were found to be upregulated at the expense of those in classes III ( $n r d D G)$ and Ia $(n r d A B)$ (Table 2) - even though all three classes are equally 


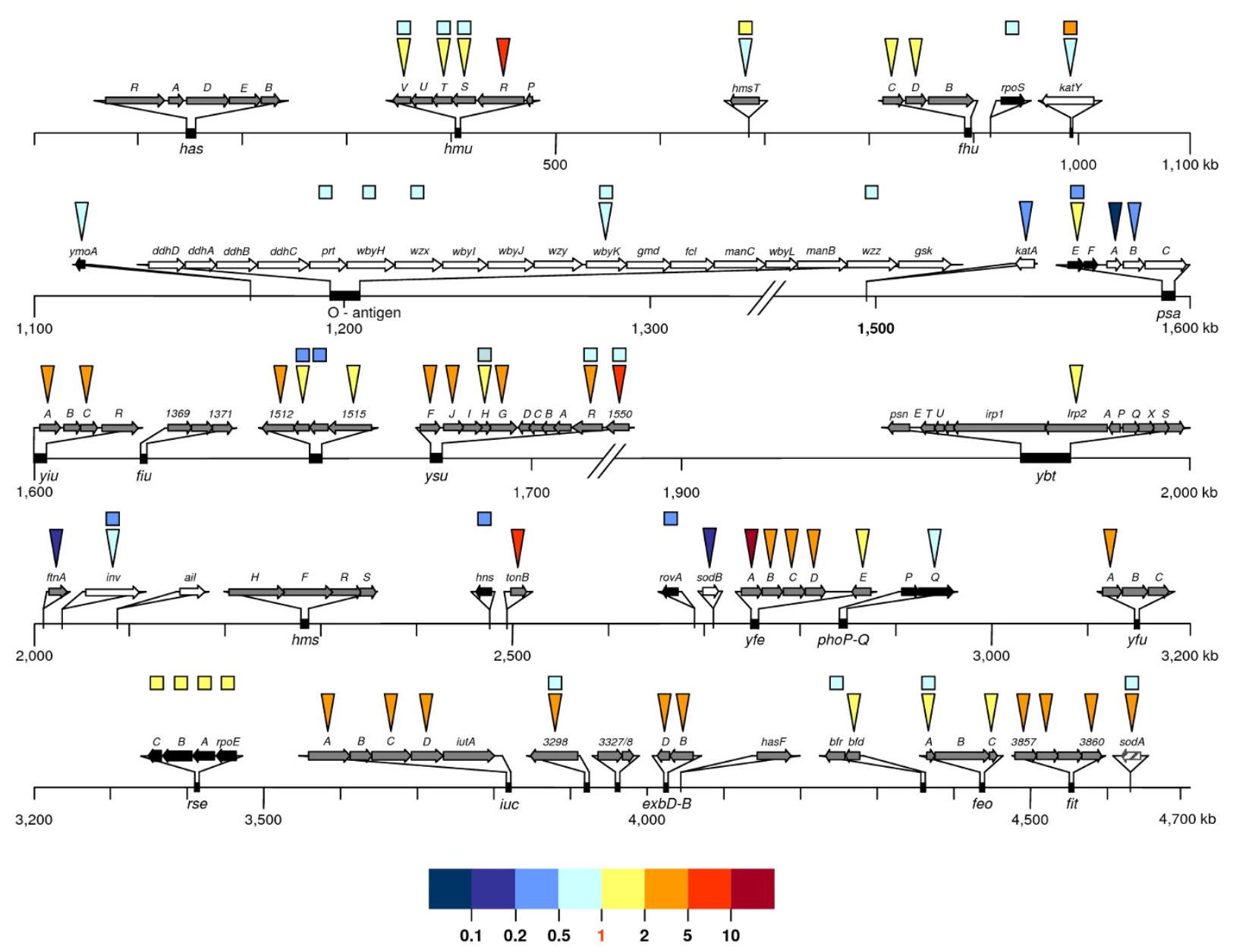

Figure I

Medium- and temperature-dependent differential expression of $Y$. pseudotuberculosis chromosomal genes involved in virulence and/or iron uptake \& storage. Significant $(p<0.05)$ upshifts (yellow to red scale) or downshifts (blue scale) in individual gene transcription levels when bacteria were grown in human plasma versus LB (triangles) and/or at $37^{\circ} \mathrm{C}$ versus $28^{\circ} \mathrm{C}$ (squares) are indicated by the color scale bar. Genes encoding iron uptake/storage systems, virulence factors and their regulators are symbolized by gray, white and black arrows, respectively. Nomenclature used for gene designation correspond to the $Y$. pseudotuberculosis IP32953 genome annotation. Mean fold changes in transcription and $p$-values are indicated in Table 2.

involved in generating the synthetic precursors for DNA. The fact that only the first class is Fur-activated [14] is consistent with this observation. Similar variations have also been recorded in $Y$. pestis [8]. However, whereas purine/ pyrimidine metabolism has been shown to be essential for Y. pestis virulence [15], the role of this metabolic pathway in the physiopathology of $Y$. pseudotuberculosis has not yet been investigated. Along with class 1b RNRs, more than half of the enzymes in the tricarboxylic acid cycle (TCA) are known to be catalytically iron-dependent and/ or believed to be transcriptionally activated by Fur [16]. Accordingly, and in line with transcriptome data from $Y$. pestis, we observed that transcription of these genes fell significantly when $Y$. pseudotuberculosis was grown in plasma.

In contrast to the low availability of iron in blood, glucose is readily available in this biological fluid and at a higher concentration (approx. $7 \mathrm{mM}$ ) than in LB broth. When $Y$. pseudotuberculosis was cultured in plasma, genes involved in glycolysis and the upstream, sugar-supplying, phosphoenolpyruvate-dependent systems were found to be upregulated, as depicted in Fig. 2. This finding is reminiscent of an aerobic phenomenon referred to as "glucose 


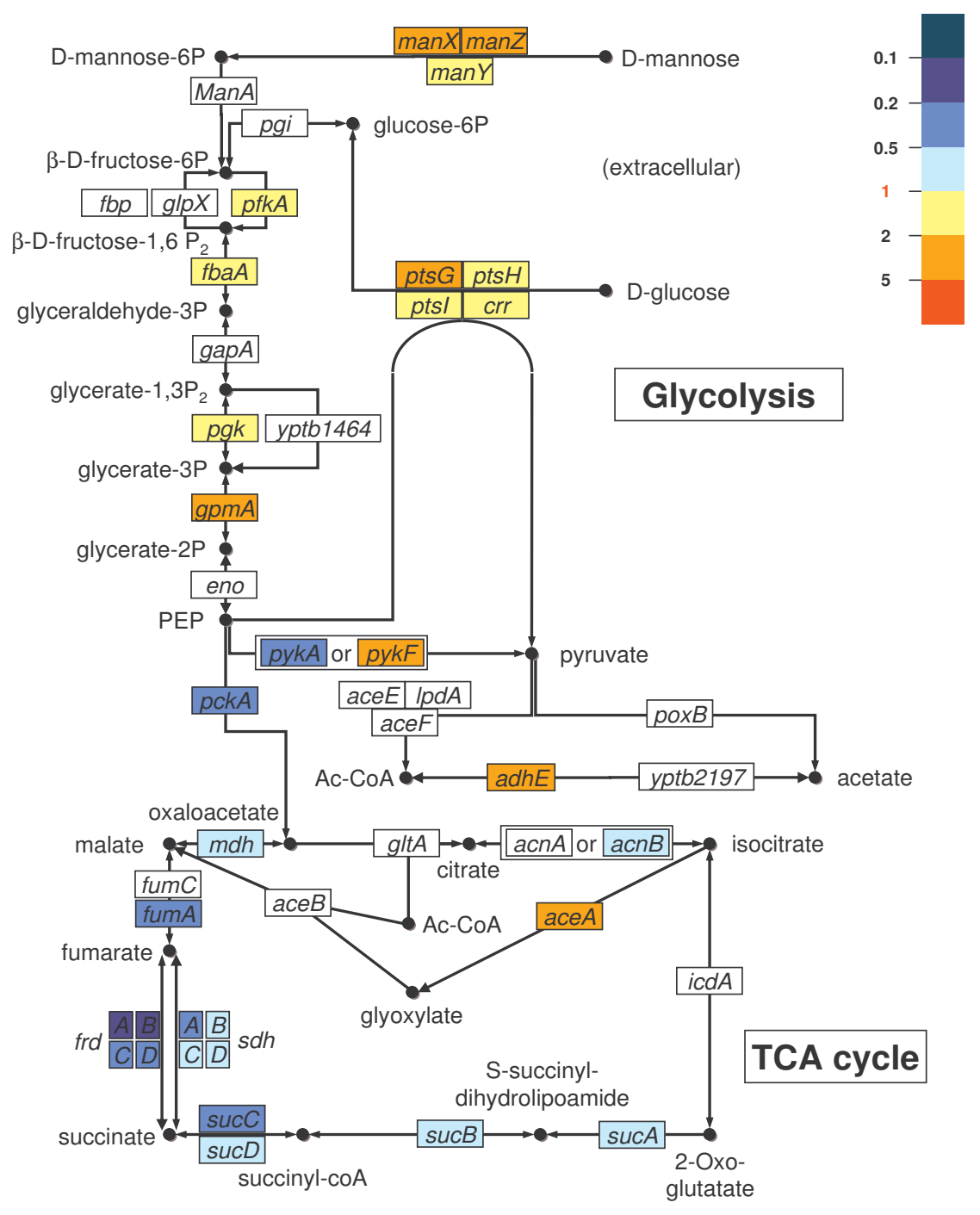

\section{Figure 2}

Medium-dependent differential expression of genes coding for enzymes putatively involved in $Y$. pseudotuberculosis glycolysis and the tricarboxylic acid cycle (TCA cycle). Significant $(p<0.05)$ upshifts (yellow to red scale) or downshifts (blue scale) in individual gene transcription levels in human plasma versus LB is indicated by the color scale bar. Open boxes indicate genes whose expression levels did not vary significantly $(p>0.05)$. Although considered as not significant by statistical analysis of macroarray data $(p=0.053)$, transcriptional upregulation of ace $B$ in human plasma was confirmed by qRT-PCR. Abbreviations: Ac-CoA: acetyl coenzyme A; PEP: phosphoenolpyruvate. Mean fold changes in transcription and $p-$ values are indicated in Table 2. 
overflow metabolism"; this consists in channeling the carbon flow towards acetate formation instead of citrate formation, in order to prevent the excessive accumulation of $\mathrm{NADH}$ that would otherwise result from very high glucose consumption rates [17]. However, one main feature of glucose overflow in $E$. coli is acetate accumulation due to a strong transcriptional repression of the glyoxylate shunt aceBAK operon [18]. Interestingly, at least the first two of these genes are not down- but are up-regulated in Y. pseudotuberculosis (Fig. 2, Additional file 1), suggesting a need for this species to limit acetate overloads. The continuous de-repression of these genes (due to inactivation of the IclR repressor) suggests that this might also be the case in $Y$. pestis. These pathways are controlled by complex and finely balanced networks involving numerous pleiotropic regulators, including Fur, Crp, Fnr and ArcA [16,19]. This unexpected upregulation may well result from the combination of both high glucose and low iron levels in plasma. Whether this occurs through the strong transcriptional repression observed with both $f n r$ and $\operatorname{arcA}$ remains to be addressed in future experiments.

Temperature upshift is typically considered to be the main signal indicating to bacteria that they have entered the host; this hypothesis is supported by the thermal dependency of almost all $Y$. pseudotuberculosis virulence genes and also many of the latter's regulators [3]. Several of these genes were also found to be influenced by growth in plasma and the changes were sometimes in the opposite direction to those seen with temperature upshifts: whereas expression of the invasin-encoding gene inv was significantly repressed during bacterial growth under both conditions, transcription of $p s a A$ (coding for the pH6 antigen) was promoted by temperature upshifts $[6,20]$, but was one of the most strongly repressed in plasma. Interestingly, the impact of this medium on psaA transcription was not considered to be significant in $Y$. pestis and suggests that the pH6 antigen does not have the same importance in blood dissemination in the two species. In contrast to the latter two adhesins, transcriptional activation of yadA (harbored by the pYV plasmid and involved in adhesion) was found to be the highest of all the Y. pseudotuberculosis genes induced under plasma growth conditions. This observation is consistent with YadA's involvement in microbial resistance to complement $[21,22]$. Similarly, $o m p C$ whose product is believed to be targeted by lactoferricin [23], a bactericidal peptide derived from lactoferrin by enzymatic cleavage [24], is strongly repressed, whilst no significant modification was observed for the outer membrane-encoding genes ompA and $o m p C 2$.

Lastly, an essential determinant of bacterial virulence is the plasmid-encoded type III secretion system (TTSS) which performs intracellular delivery of a set of Yersinia outer proteins (Yops) that subvert the host's defenses [25]. Interestingly, $Y$. pseudotuberculosis growth in plasma induced the upregulation of 25 genes required for secretion, translocation and chaperoning of the Yop effector proteins in a similar fashion to that observed upon temperature upshift (Fig. 3). Furthermore, the apparently coordinated regulation of yadA and the TTSS-encoding genes by temperature and growth in plasma suggests the involvement of a common means of genetic control. YmoA (a chromatin-associated (histone-like) protein which is very similar in structure and function to the haemolysin expression modulating protein Hha from Escherichia coli) was shown to negatively influence YadA and Yop expression by favoring supercoiling of the pYV plasmid [26]. A two-fold reduction in $y m o A$ transcription in plasma may be enough to contribute to the TTSS upregulation recorded in Y. pseudotuberculosis. Strikingly, this plasma-induced TTSS activation was not observed in $Y$. pestis, since only 3 out of the 25 genes mentioned above were found to be upregulated (in line with the statistically non-significant downregulation of $y m o A$ ); this raises the possibility that these two pathogenic Yersinia species may differ in their transcriptional regulation of pYV-harbored virulence genes.

\section{Conclusion}

Overall transcription profiling of $Y$. pseudotuberculosis grown in an environment mimicking the blood stage of the infectious process revealed gene regulations that could not be anticipated from the results of previously reported single-stimulus studies. Our findings thus provide insight into how a number of simultaneously sensed environmental cues may be taken into account by the bacterium in a hierarchical manner. Furthermore, comparison of our analyses with those previously performed in $Y$. pestis suggests that transcription of common critical virulence factors may be differently influenced (at least in part) by the plasma environment in these two species.

\section{Methods \\ DNA macroarray construction}

Pairs of specific oligonucleotide primers were designed with the Primer 3 software for each of the 3,951 Y. pseudotuberculosis IP32953 CDSs. In order to avoid cross-hybridization, the specificity of the PCR products relative to the complete genome sequence was tested with CAAT-box software [27]. Primers purchased from Eurogentec were chosen in order to specifically amplify a $\approx 400$ to 500 base pair (bp) fragment of each open reading frame (ORF), with a melting temperature of 51 to $60^{\circ} \mathrm{C}$. Amplification reactions were performed in 96-well plates (Perkin-Elmer) in a $100 \mu \mathrm{l}$ reaction volume containing $100 \mathrm{ng}$ of $Y$. pseudotuberculosis IP32953 DNA, DNA polymerase (Dynazyme, New England Biolabs), $10 \mu \mathrm{M}$ of each primer and $2 \mathrm{mM}$ dNTPs (Perkin-Elmer). Reactions were cycled 

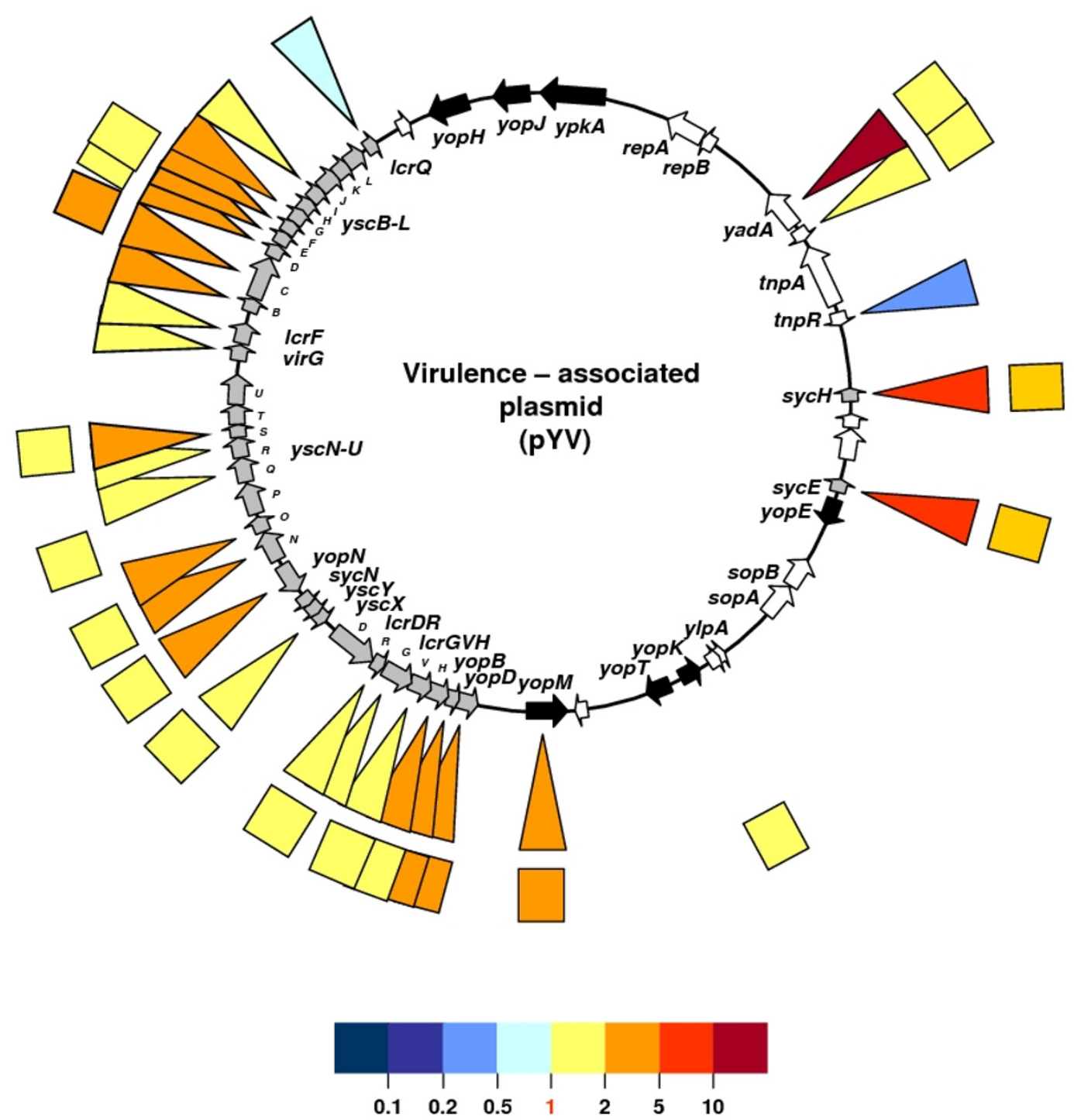

\section{Figure 3}

Medium- and temperature-dependent differential expression of genes harbored by the $Y$. pseudotuberculosis virulence plasmid pYV. Significant $(p<0.05)$ upshifts (yellow to red scale) or downshifts (blue scale) in individual gene transcription levels when bacteria were grown in human plasma versus LB (triangles) and/or at $37^{\circ} \mathrm{C}$ versus $28^{\circ} \mathrm{C}$ (squares) are indicated by the color scale bar. Only genes spotted on the macroarray (56 out of 99 pYV-borne genes) are shown and those encoding the secretion apparatus and Yop effectors are represented by grey and black boxes, respectively. Mean fold changes in transcription and $p$-values are indicated in Table 3. 
45 times $\left(94^{\circ} \mathrm{C}\right.$ for $30 \mathrm{~s} ; 60^{\circ} \mathrm{C}$ for $30 \mathrm{~s} ; 72^{\circ} \mathrm{C}$ for $\left.60 \mathrm{~s}\right)$ with a final cycle of $72^{\circ} \mathrm{C}$ for $7 \mathrm{~min}$ in a thermocycler. Each PCR product was checked by agarose gel electrophoresis and when DNA amplification was unsuccessful, PCR was repeated with another primer set. Overall, 3,951 of the 3,994 CDSs (98\%) identified in the Y. pseudotuberculosis IP32953 genome were successfully amplified under our experimental conditions. ORF-specific PCR products, luciferase DNA (10 to $100 \mathrm{ng}$ ) and total genomic DNA from strain IP32953 were spotted onto $22 \times 7$-cm nylon membranes (Genetix) using a Qpix robot (Genetix). Immediately following spot deposition, membranes were immersed for $15 \mathrm{~min}$ in $0.5 \mathrm{M} \mathrm{NaOH}$ and $1.5 \mathrm{M} \mathrm{NaCl}$, washed three times with distilled water and stored at $20^{\circ} \mathrm{C}$ until use. To ensure that DNA samples were successfully deposited on the membranes, 33P-labeled genomic DNA was hybridized to the macroarray before transcriptome analysis.

\section{Bacterial culture}

The Y. pseudotuberculosis transcriptome was studied in three independent cultures of strain IP32953 in media aliquoted from a single batch. After storage in Luria-Bertani (LB) broth with $40 \%$ glycerol at $-80^{\circ} \mathrm{C}$, the strain was thawed and then grown on LB agar supplemented with 20 $\mu \mathrm{g} \mathrm{ml}-1$ hemin for $48 \mathrm{~h}$ at $28^{\circ} \mathrm{C}$. From this culture, $8 \times 10^{6}$ cells were inoculated into $40 \mathrm{ml}$ of either LB broth or pooled human plasma from healthy donors (heated at $56^{\circ} \mathrm{C}$ for $30 \mathrm{~min}$ to ensure complement inactivation). Media were then incubated at $28^{\circ} \mathrm{C}$ or $37^{\circ} \mathrm{C}$ with shaking and Yersinia growth was monitored by absorbance at 600 $\mathrm{nm}$.

\section{RNA and CDNA probe preparation}

Cells were harvested from exponential-phase cultures ( $A_{600}$ of $0.2-0.4$ and $0.1-0.2$ for LB and human plasma, respectively) by centrifugation at $4^{\circ} \mathrm{C}$ and the pelleted bacteria were disrupted with RNAwiz reagent (Ambion). After mixing the lysate with chloroform $(0.2 \mathrm{v})$, total RNA was precipitated from the aqueous phase with glycogen $(1 / 50 \mathrm{v})$ and isopropanol $(1 \mathrm{v})$. The RNA pellet was washed with 70\% ethanol and then dissolved in sterile, DNase- and RNase-free water. Contaminating DNA was removed using the DNA-free kit from Ambion. Nucleic acid purity and integrity was checked with a BioAnalyzer 2100 (Agilent) according to the supplier's instructions. After quantification by spectrophotometry at 260 and 280 $\mathrm{nm}$, the RNA solution was stored at $-80^{\circ} \mathrm{C}$ until use. cDNA was further generated from $10 \mu \mathrm{g}$ of total RNA incubated (in a total volume reaction of $45 \mu \mathrm{l}$ ) for $3 \mathrm{~h}$ at $42^{\circ} \mathrm{C}$ with 50 U AMV reverse transcriptase (Roche), 0.35 pmol. of each amplified CDS-specific 3' oligonucleotide primer, $222 \mu \mathrm{M}$ dATP, dGTP \& dTTP, $2.2 \mu \mathrm{M}$ dCTP and $50 \mu \mathrm{Ci}$ 33P-labelled dCTP (Amersham Biosciences). Labeled
cDNA was purified to remove unincorporated nucleotides using DyeEx 2.0 spin column (Qiagen).

\section{DNA macroarray hybridization}

Macroarrays were prewetted in $2 \times \operatorname{SSPE}(0.18 \mathrm{M} \mathrm{NaCl}, 10$ $\mathrm{mM} \mathrm{NaH} \mathrm{PO}_{4}, 1 \mathrm{mM}$ EDTA, pH 7.7) and prehybridized for $1 \mathrm{~h}$ in $13 \mathrm{ml}$ of hybridization solution $(5 \times \mathrm{SSPE}, 2 \%$ SDS, $1 \times$ Denhardt's reagent, $0.1 \mathrm{mg}$ of sheared salmon sperm DNA ml-1) at $65^{\circ} \mathrm{C}$ in roller bottles. Hybridization was carried out for $20 \mathrm{~h}$ at $65^{\circ} \mathrm{C}$ with $15 \mathrm{ml}$ of hybridization solution containing the purified cDNA probe. After hybridization, membranes were washed three times at room temperature and three times at $65^{\circ} \mathrm{C}$ for $20 \mathrm{~min}$ in $0.5 \times$ SSPE and $0.2 \%$ SDS. Probed macroarrays were exposed to a phosphor screen (Molecular Dynamics) for 24-72 $\mathrm{h}$ and imaged using a STORM 860 phosphorimager (Amersham Biosciences). The intensity of all of the pixels associated with each spot was further quantified using ArrayVision software (Imaging Research, Grinnel, IA, USA). The experiment design included three biological replicates for each combination of conditions. Data were analyzed using the SAS software (SAS Institute Inc, Cary, NC, USA). They were first log-transformed and normalized with a median normalization. A linear model was then applied on each gene with the temperature, phase and growth medium as fixed effects. The significance level alpha was set to 0.05 .

\section{Real-Time Quantitative PCR}

Messenger RNAs (mRNAs) were reverse transcribed from $1 \mu \mathrm{g}$ of nucleic acid by using the High-Capacity cDNA Archive Kit (Applied Biosystems, Foster City, CA) according to the manufacturer's instructions. The resulting cDNA was amplified by the SYBR Green Real-Time PCR Kit and detected on a Prism 7000 detection system (Applied Biosystems). The forward and reverse primers used were as follows: 5'CGCCATCAAATGCGCTAAT3' and 5'TGAGCGGGATCGTGTTCAA3' for $y f e A$, 5'TCAA GCAGGGAAACACATTCC3' and 5'GGCTGTTTAC CCGC AAAAATC3' for $p s a A$, 5'GGTTAGCCGCGAACA GGATA3' and 5'CGCTCGCCAGAACAAGGTT3' for aceB, 5'TCGA TGCTCGCGCTAAGG3' and 5'GCTGGTTTCGCTGCTT CAG3' for yadA, 5'GATCCTGGTTCCATAAAAATTATT CAC3' and 5'ATTGTTCGCCTGGATTACCAA3' for yopJ, 5'GAGAATCCCAGTCGGGTGTTAA3' and 5'TCACTGCA TCGCGGT AGGT3' for yopN, 5'GACACCAGTGGGACGCAA CT3' and 5'GGGTTCACAAGAAAGAGTAACAGCTT3' for $s y c H, 5^{\prime}$ GGTTACGCGCGGGTATCA3' and 5'CCGCG TCTTTGAGTGTTTTG3' for $t n p R$, 5'TTCTCGTGGGCAAC CTATCC3' and 5'TGCGTTCCCAGCATACACAA3' for $n l p D$. On completion of the PCR amplification, a DNA melting curve analysis was performed to confirm the presence of a single amplicon. Relative mRNA levels $\left(2^{\Delta \Delta \mathrm{C}}\right)$ were determined by comparing the PCR cycle thresholds (Ct) for the gene of interest and the constitutively 
expressed YPTB0775 gene (spot ID YPO3356) coding for the outer membrane lipoprotein NlpD.

\section{Abbreviations}

qRT-PCR: quantitative Real Time Reverse Transcription PCR.

\section{Authors' contributions}

MLR performed the macroarray hybridizations and participated to the critical proofreading of the manuscript. SC contributed to the experiment set-up and was responsible for bacterial cultures and RNA extractions; she participated in statistical analyses and critical proofreading of the manuscript. RD performed the qPCR experiments. CL, $\mathrm{LF}, \mathrm{CL}, \mathrm{AS}, \mathrm{J}-\mathrm{YC}$ and $\mathrm{CM}$ were involved in the macroarray design and construction. MAD contributed to the experiment design and performed the statistical analyses. JF contributed to the bacterial cultures. EC participated in experimental design and, as the main project coordinator, in critical proofreading of the manuscript. MM contributed to the experimental set-up, performed the spot intensity quantification and the biological interpretation of the results; he wrote this manuscript with assistance of MS, who was also involved in coordination of the project. All the authors have read and approved the content of this article.

\section{Additional material}

\section{Additional file 1}

Validation of macroarray hybridization data. Transcriptional changes for three chromosomal (yfeA, psaA and $\mathrm{aceB}$ ) and five plasmid-borne (yadA, yopJ, yopN, sycH and tnpR) genes (assessed using macroarray hybridization and qRT-PCR assays) are shown.

Click here for file

[http://www.biomedcentral.com/content/supplementary/14712180-8-211-S1.pdf]

\section{Acknowledgements}

This work was funded by grant 0234021 from the "Délégation Générale pour l'Armement" and grant PTR88 from the Institut Pasteur and the Institut Pasteur de Lille. We gratefully thank Sandrine Rousseau-Moreira (PlateForme 4, Institut Pasteur, Paris, France) for technical assistance during the Genoscript data upload process.

\section{References}

I. Vincent P, Leclerc A, Martin L, Yersinia Surveillance Network, Duez J$M$, Simonet $M$, Carniel $E$ : Sudden onset of pseudotuberculosis in humans, France, 2004-05. Emerg Infect Dis 2008.

2. Putzker M, Sauer H, Sobe D: Plague and other human infections caused by Yersinia species. Clin Lab 200I, 47(9-10):453-466.

3. Marceau M: Transcriptional regulation in Yersinia: an update. Curr Issues Mol Biol 2005, 7(2): I5I-I77.

4. Darwin AJ: Genome-wide screens to identify genes of human pathogenic Yersinia species that are expressed during host infection. Curr Issues Mol Biol 2005, 7(2): I35- I 49.

5. Revell PA, Miller VL: Yersinia virulence: more than a plasmid. FEMS Microbiol Lett 200I, 205(2): I59-164.
6. Price SB, Freeman MD, Yeh KS: Transcriptional analysis of the Yersinia pestis pH 6 antigen gene. J Bacteriol 1995, 177(20):5997-6000.

7. Collyn F, Lety MA, Nair S, Escuyer V, Ben Younes A, Simonet M, Marceau M: Yersinia pseudotuberculosis harbors a type IV pilus gene cluster that contributes to pathogenicity. Infect Immun 2002, 70( I I):6196-6205.

8. Chauvaux S, Rosso ML, Frangeul L, Lacroix C, Labarre L, Schiavo A, Marceau M, Dillies MA, Foulon J, Coppée JY, Médigue C, Simonet M, Carniel E: Transcriptome analysis of Yersinia pestis in human plasma: an approach for discovering bacterial genes involved in septicaemic plague. Microbiology 2007, I 53(9):3 | |2-3 I 24.

9. Chain PS, Carniel E, Larimer FW, Lamerdin J, Stoutland PO, Regala WM, Georgescu AM, Vergez LM, Land ML, Motin VL, Brubaker RR, Fowler J, Hinnebusch J, Marceau M, Médigue C, Simonet M, ChenalFrancisque V, Souza B, Dacheux D, Elliott JM, Derbise A, Hauser LJ, Garcia E: Insights into the evolution of Yersinia pestis through whole-genome comparison with Yersinia pseudotuberculosis. Proc Natl Acad Sci USA 2004, 10 I (38): I 3826-I 383 I.

10. Andrews SC, Robinson AK, Rodriguez-Quinones F: Bacterial iron homeostasis. FEMS Microbiol Rev 2003, 27(2-3):215-237.

II. Schaible UE, Kaufmann SH: Iron and microbial infection. Nat Rev Microbiol 2004, 2( I 2):946-953.

12. Abdul-Tehrani H, Hudson AJ, Chang YS, Timms AR, Hawkins C, Williams JM, Harrison PM, Guest JR, Andrews SC: Ferritin mutants of Escherichia coli are iron deficient and growth impaired, and fur mutants are iron deficient. I Bacteriol 1999, 18I(5): I4I5-1428.

13. Sanyal I, Cohen G, Flint DH: Biotin synthase: purification, characterization as a [2Fe-2S]cluster protein, and in vitro activity of the Escherichia coli bioB gene product. Biochemistry 1994, 33( I 2):3625-363I.

14. Nordlund P, Reichard P: Ribonucleotide reductases. Annu Rev Biochem 2006, 75:68I-706.

15. Munier-Lehmann H, Chenal-Francisque V, lonescu M, Chrisova P, Foulon J, Carniel E, Barzu O: Relationship between bacterial virulence and nucleotide metabolism: a mutation in the adenylate kinase gene renders Yersinia pestis avirulent. Biochem J 2003, 373(2):515-522.

16. Zhang Z, Gosset G, Barabote R, Gonzalez CS, Cuevas WA, Saier MH Jr: Functional interactions between the carbon and iron utilization regulators, Crp and Fur, in Escherichia coli. J Bacteriol 2005, I 87(3):980-990.

17. Vemuri GN, Altman E, Sangurdekar DP, Khodursky AB, Eiteman MA: Overflow metabolism in Escherichia coli during steady-state growth: transcriptional regulation and effect of the redox ratio. Appl Environ Microbiol 2006, 72(5):3653-366I.

18. Veit A, Polen T, Wendisch VF: Global gene expression analysis of glucose overflow metabolism in Escherichia coli and reduction of aerobic acetate formation. Appl Microbiol Biotechnol 2007, 74(2):406-42I.

19. Perrenoud A, Sauer U: Impact of global transcriptional regulation by ArcA, ArcB, Cra, Crp, Cya, Fnr, and Mlc on glucose catabolism in Escherichia coli. J Bacteriol 2005, 187(9):3171-3179.

20. Lindler LE, Klempner MS, Straley SC: Yersinia pestis pH 6 antigen: genetic, biochemical, and virulence characterization of a protein involved in the pathogenesis of bubonic plague. Infect Immun 1990, 58(8):2569-2577.

21. El Tahir Y, Skurnik M: YadA, the multifaceted Yersinia adhesin. Int J Med Microbiol 200I, 29 I (3):209-2I8.

22. China B, Sory MP, Nguyen BT, Debruyere M, Cornelis GR: Role of the YadA protein in prevention of opsonization of Yersinia enterocolitica by C3b molecules. Infect Immun 1993, 6I(8):3|29-3|36.

23. Sallmann FR, Baveye-Descamps S, Pattus F, Salmon V, Branza N, Spik G, Legrand D: Porins OmpC and PhoE of Escherichia coli as specific cell-surface targets of human lactoferrin. Binding characteristics and biological effects. J Biol Chem 1999, 274(23): $16107-16 \mid 14$.

24. Orsi N: The antimicrobial activity of lactoferrin: current status and perspectives. Biometals 2004, 17(3): 189-196.

25. Cornelis GR: The Yersinia Ysc-Yop 'type III' weaponry. Nat Rev Mol Cell Biol 2002, 3( ( 0):742-752.

26. Cornelis GR, Sluiters C, Delor I, Geib D, Kaniga K, Lambert de Rouvroit C, Sory MP, Vanooteghem JC, Michiels T: ymoA, a Yersinia 
enterocolitica chromosomal gene modulating the expression of virulence functions. Mol Microbiol I99I, 5(5): I023-I034.

27. Frangeul L, Glaser P, Rusniok C, Buchrieser C, Duchaud E, Dehoux $P$, Kunst F: CAAT-Box, Contigs-Assembly and Annotation ToolBox for genome sequencing projects. Bioinformatics 2004, 20(5):790-797.

28. Tatusov RL, Galperin MY, Natale DA, Koonin EV: The COG database: a tool for genome-scale analysis of protein functions and evolution. Nucleic Acids Res 2000, 28(I):33-36.

Publish with Bio Med Central and every scientist can read your work free of charge

"BioMed Central will be the most significant development for disseminating the results of biomedical research in our lifetime. " Sir Paul Nurse, Cancer Research UK

Your research papers will be:

- available free of charge to the entire biomedical community

- peer reviewed and published immediately upon acceptance

- cited in PubMed and archived on PubMed Central

- yours - you keep the copyright

Submit your manuscript here:

http://www.biomedcentral.com/info/publishing_adv.asp
BioMedcentral 